\title{
Axillary lymph node involvement in breast cancer: prognostic and surgical implications in the sentinel node era
}

Citation for published version (APA):

Kuijt, G. P. (2014). Axillary lymph node involvement in breast cancer : prognostic and surgical implications in the sentinel node era. [Doctoral Thesis, Maastricht University]. Datawyse / Universitaire Pers Maastricht. https://doi.org/10.26481/dis.20141016gk

Document status and date:

Published: 01/01/2014

DOI:

10.26481/dis.20141016gk

Document Version:

Publisher's PDF, also known as Version of record

\section{Please check the document version of this publication:}

- A submitted manuscript is the version of the article upon submission and before peer-review. There can be important differences between the submitted version and the official published version of record.

People interested in the research are advised to contact the author for the final version of the publication, or visit the DOI to the publisher's website.

- The final author version and the galley proof are versions of the publication after peer review.

- The final published version features the final layout of the paper including the volume, issue and page numbers.

Link to publication

\footnotetext{
General rights rights.

- You may freely distribute the URL identifying the publication in the public portal. please follow below link for the End User Agreement:

www.umlib.nl/taverne-license

Take down policy

If you believe that this document breaches copyright please contact us at:

repository@maastrichtuniversity.nl

providing details and we will investigate your claim.
}

Copyright and moral rights for the publications made accessible in the public portal are retained by the authors and/or other copyright owners and it is a condition of accessing publications that users recognise and abide by the legal requirements associated with these

- Users may download and print one copy of any publication from the public portal for the purpose of private study or research.

- You may not further distribute the material or use it for any profit-making activity or commercial gain

If the publication is distributed under the terms of Article $25 \mathrm{fa}$ of the Dutch Copyright Act, indicated by the "Taverne" license above, 


\section{Axillary lymph node involvement in breast cancer Prognostic and surgical implications in the sentinel node era}

\section{Gerrit Paulus Kuijt}

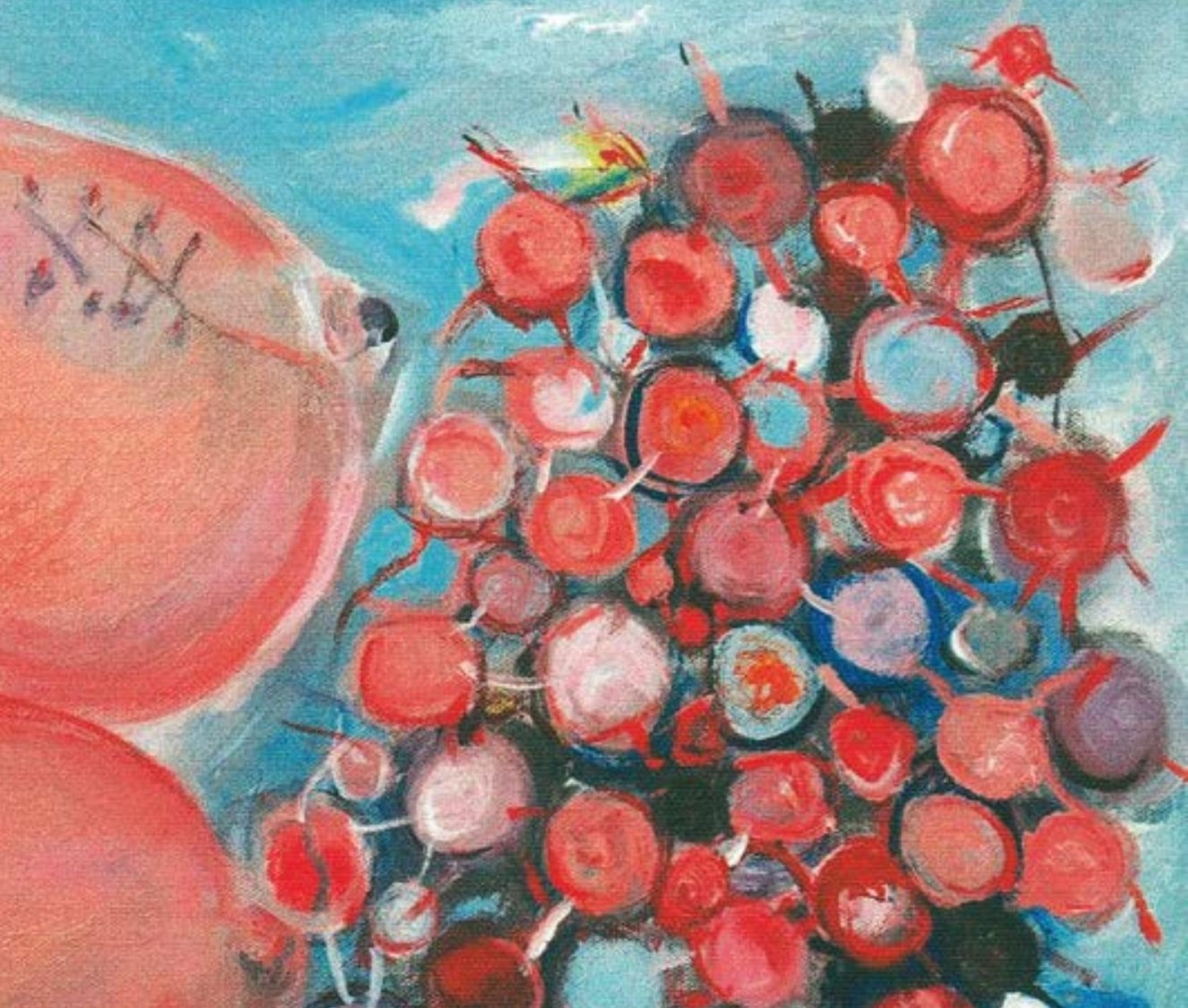


(c) Copyright Gerrit Paulus Kuijt, Maastricht 2014

ISBN 978-90-822702-0-4

Uitgeverij: Neopred Kuijt B.V.

Layout: Tiny Wouters

Cover design and production: Datawyse | Universitaire Pers Maastricht

The painting on the cover was made for the second symposium of the Caribbean Association of Oncology \& Haematology by Jean Girigori, a painter from Curaçao. It depicts the pain of having breast cancer. 


\title{
Axillary lymph node involvement in breast cancer
}

\author{
Prognostic and surgical implications \\ in the sentinel node era
}

\author{
PROEFSCHRIFT \\ ter verkrijging van de graad van doctor aan de Universiteit Maastricht, \\ op gezag van de Rector Magnificus, prof. dr. L.L.G. Soete \\ volgens het besluit van het College van Decanen, \\ in het openbaar te verdedigen \\ op donderdag 16 oktober 2014 om 14.00 uur \\ door \\ Gerrit Paulus Kuijt
}


Promotor

Prof. dr. V.C.G. Tjan-Heijnen

Co-promotores

Dr. R.M.H. Roumen (Máxima Medisch Centrum, Veldhoven)

Dr. A.C. Voogd

Beoordelingscommissie

Prof. dr. H.J.T. Rutten (voorzitter)

Prof. dr. ir. P.A. van den Brandt

Dr. Th. van Dalen (Diakonessenhuis, Utrecht)

Dr. M.L. Smidt 


\section{Contents}

Chapter 1 Introduction and outline of the thesis

Chapter 2 Treatment of 100 patients with sentinel node-negative

breast cancer without further axillary dissection

Chapter 3 Survival after negative sentinel lymph node biopsy in

breast cancer at least equivalent to after negative extensive axillary dissection

Chapter 4 Second thoughts on sentinel lymph node biopsyin

node-negative breast cancer

Chapter 5 The prognostic significance of axillary lymph-node micrometastasis in breast cancer patients

Chapter 6 The significance of one positive axillary node

Chapter 7 Value of Memorial Sloan-Kettering Cancer Center nomogram

in clinical decision making for sentinel lymph node-positive breast cancer

Chapter 8 A head to head comparison of nine tools predicting non-sentinel lymph node status in sentinel node positive breast cancer women

Chapter 9 Summary, general discussion and future perspectives

Samenvatting

Valorisation

Dankwoord 



\section{Introduction and outline of the thesis}

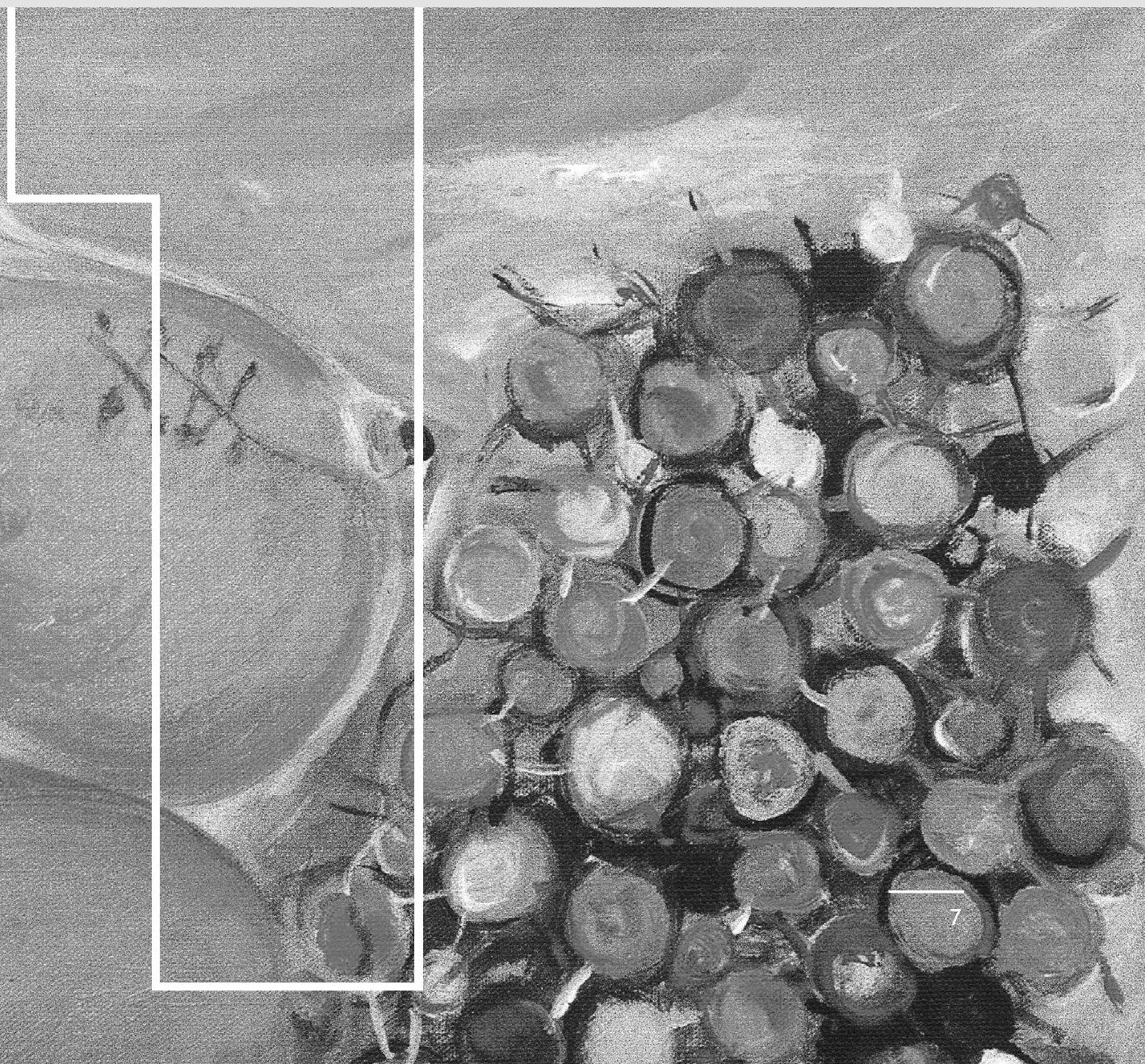


Chapter 1 


\section{Breast cancer}

The world wide incidence of breast cancer currently is around 1.5 million per year ${ }^{1}$. In the Western world, up to one in eight women will develop breast cancer during their life time ${ }^{1}$. Most of these women will undergo a surgical procedure to remove the primary breast tumour as well as a surgical procedure to evaluate the axillary lymph nodes. The latter is important because breast cancer prognosis is heavily determined by axillary lymph node status ${ }^{2}$.

The role of surgery in the treatment of primary breast cancer has changed over time. More than 100 years ago, professor William Stuart Halsted of the Johns Hopkins Hospital recommended a radical mastectomy for the treatment of breast cancer ${ }^{3}$. In this procedure, the breast containing the tumour was resected as well as the underlying pectoral muscles and the regional lymph nodes ${ }^{4}$. This often resulted in pain and significant shoulder dysfunction, but increased the 20 year survival rate from 10 to $50 \%{ }^{4}$. The Halstedian paradigm suggested that there is an anatomic basis to breast cancer spread ${ }^{5}$. Theoretically, this meant that breast cancer could be cured if it was possible to surgically remove all tumour mass. The discussion resulting from this paradigm was concentrated around the amount of tissue that needed to be removed to optimize treatment results. By mid-century, however, it became clear that breast cancer was more than just a localized disorder and that breast cancer may in fact be better understood when viewed as being a systemic disease with a localized component ${ }^{5}$. This resulted in the initiation of several clinical practice changing randomized controlled trials comparing breast-conserving surgery with the more invasive (modified) radical mastectomy ${ }^{6,7}$. It also resulted in the development of systemic treatment modalities such as endocrine therapy and cytotoxic drugs. Also influencing the trend towards less invasive surgery was the development of radiation therapy techniques. At the same time, the increased use of mammography and the introduction of breast cancer screening resulted in diagnosing breast cancer at an earlier stage, increasing the percentage of breast cancer women who received breast conserving treatment. The axillary lymph node dissection, however, remained the standard of care for the staging of the axilla. This did not change until the 1990's when the sentinel node concept was also found to be applicable to breast cancer ${ }^{8,9}$. The introduction of the sentinel node concept can now be seen as a paradigm shift regarding the staging of the axilla.

The sentinel node procedure is based on the premise that if the first lymph node the breast tissue drains into does not contain tumour cells, that then the remaining axillary lymph nodes are also clear of metastases and therefore do not need to be removed. Sentinel nodes are generally identified after injecting both radioactive colloid and blue dye. Lymph nodes that become radioactive or blue are judged to be the sentinel nodes, and subsequently removed during this surgical staging procedure. 
A negative sentinel lymph node biopsy implies that a completion axillary lymph node dissection is not necessary, thereby reducing the risk of side-effects of this procedure such as lymph oedema, pain and shoulder dysfunction ${ }^{10}$. The introduction of the sentinel lymph node biopsy procedure however, raised many new questions, some of which are addressed in this thesis.

\section{Outline of this thesis}

This thesis presents studies that evaluate the shift in breast cancer treatment from standard axillary lymph node dissection to the sentinel node procedure. The first three chapters cover studies on the safety of doing a sentinel node procedure only in women without sentinel lymph node metastases. The other four chapters describe studies searching for patient characteristics associated with non-sentinel node involvement. The aim of these studies was to identify those patients in whom axillary lymph node dissection might safely be avoided, despite the presence of sentinel lymph node metastases.

Chapter 2 reports the early results of the first 100 consecutive women with sentinel node negative breast cancer without further axillary lymph node dissection, treated at the Máxima Medical Centre in Veldhoven in the south of the Netherlands. While the sentinel lymph node biopsy had already been studied in technical feasibility and proof of concept studies ${ }^{11,12}$, and while randomized trials were being set up ${ }^{13}$, this study evaluated the clinical outcome, looking specifically at axillary tumour recurrence and assessing the morbidity of the sentinel lymph node biopsy. Special attention was paid to axillary or loco-regional recurrence, distant metastases and overall survival. Morbidity was assessed one year after the sentinel lymph node biopsy procedure to see if it was associated with any functional impairment of the arm or shoulder.

The Eindhoven Cancer Registry has been collecting extensive patient, treatment, and outcome data since the 1950's. Here, professional data registry clerks and trained epidemiologists collect and evaluate the data of all patients with cancer diagnosed in the community hospitals in the South-Eastern Netherlands. This created the opportunity to compare the outcome of patients without axillary metastases after axillary lymph node dissection to the outcome of patients with a negative sentinel lymph node biopsy. The results of this study are reported in Chapter 3. While obviously it is preferable to have outcome data from large randomized trials with long follow up, this study looked at the short-term overall survival rate to provide a first impression on the safety of the sentinel node procedure.

As time passes, the number of patients developing recurrent disease continues to increase and short-term results may provide an incomplete and sometimes too 
optimistic picture of the performance of a new intervention. For patients with sentinel node negative breast cancer without further axillary lymph node dissection, long-term follow-up is needed to determine the safety of this minimally invasive staging technique. Chapter 4 presents the long-term outcome after a median follow-up of 6.5 years of these first 100 women with sentinel node negative breast cancer without further axillary lymph node dissection, presented in Chapter 2. Again the emphasis was on the risk of axillary recurrence.

Breast cancer treatment guidelines have recommended the use of a completion axillary lymph node dissection in patients with a sentinel lymph node containing metastatic disease $\mathrm{e}^{14}$. However, it soon became clear that in up to $50-70 \%$ of these patients, the sentinel node was the only positive lymph node and no metastatic disease was present in the axillary specimen containing the other (non-sentinel) lymph nodes ${ }^{15}$. This observation started the search for patient populations with a positive sentinel lymph node in whom completion axillary lymph node dissection might be safely omitted.

Hence, in the study reported in Chapter $\mathbf{5}$ we changed our focus of study to sentinel lymph node positive breast cancer patients. An old controversy on the prognostic significance of tumour deposits smaller than $2.0 \mathrm{~mm}$ was made prominent by the sentinel node procedure because of routine use of serial sectioning and immunohistochemical (IHC) staining ${ }^{16}$. IHC staining allows for the increased detection of so-called isolated tumour cells (tumour deposits smaller than $0.2 \mathrm{~mm}$ ) and micrometastasis (tumour deposits of between 0.2 and $2.0 \mathrm{~mm}$ ). We hypothesized that patients with the smaller-sized micrometastases had a more favourable prognosis than those with macrometastases and used patient and outcome data of the population-based Eindhoven Cancer Registry to test this hypothesis. Of note, all these patients had undergone a complete axillary lymph node dissection, as at that time no long-term follow-up information was available yet for the patients with micro- or macrometastatic disease detected following sentinel node biopsy. The survival of three patient groups was compared, all after axillary clearance: those without axillary metastasis, those with micrometastasis, and a third group with macrometastasis in only one axillary lymph node (using haematoxylin and eosin staining in the presentinel node era).

In Chapter 6, outcome data of the Eindhoven Cancer Registry were used to analyze the clinico-pathological difference between breast cancer patients with only one metastatic lymph node to those with more than one pathologic lymph node, all after routine axillary lymph node clearance and haematoxylin/eosin staining (before the sentinel node era). The idea was that the group with only one positive lymph node in an axillary clearance specimen could be considered as a sentinel node positive patient in whom no additional metastases are found at axillary clearance. Even though there 
is a difference in pathological workup between axillary dissection and sentinel lymph node biopsy specimens, this study offered a way to find relevant clinicopathological characteristics associated with only one positive lymph node in which axillary clearance might safely be avoided.

Other prominent breast cancer units were also on the trail of trying to identify sentinel node positive breast cancer patients in whom axillary clearance could be avoided. The first to develop a mathematical predictive system was the breast cancer group at Memorial Sloan-Kettering Cancer Center (MSKCC) ${ }^{17}$. Chapter 7 evaluates the value of the MSKCC nomogram for individual decision-making using a cohort of patients with a low risk of additional non-sentinel node metastases, diagnosed and treated at the Máxima Medical Centre in the Netherlands. The specificity and false negative rates were calculated for three subgroups: those with a predicted risk of 5 , 10 , and 15 percent. Receivers operating characteristic curves were made and the area under the curve was calculated for each subgroup.

Multiple other breast cancer units worldwide developed their own mathematical prediction models. Chapter 8 presents the evaluation of these models using data from the Máxima Medical Center of patients diagnosed between 2000-2008. The aim was to externally validate and compare the available predictive models. The models validated were: the MSKCC nomogram, the Stanford nomogram, the Mayo nomogram, the Cambridge nomogram, the Gur nomogram, MOU nomogram, and the Saidi, the Tenon and the MC Andersen scores. Model performance was assessed using measures of calibration (calibration line slope and intercept), discrimination (area under the receiver operating characteristic curve), explained variation, and the false negative rate. The calculated values of the different measures of performance were critically evaluated.

Chapter 9 gives a summary of the thesis, the general conclusions that can be drawn from the studies, and future perspectives on the role of operative procedures for evaluating axillary lymph node status in primary breast cancer patients. 


\section{References}

1. Breast Cancer Statistics Worldwide | Worldwide Breast Cancer [Internet]. [Accessed 14 October 2012]. http://www.worldwidebreastcancer.com/learn/breast-cancer-statistics-worldwide/.

2. Carter CL, Allen C, Henson DE. Relation of tumor size, lymph node status, and survival in 24,740 breast cancer cases. Cancer 1989;63:181-7.

3. Halsted WS. I. The Results of Radical Operations for the Cure of Carcinoma of the Breast. Ann Surg 1907;46:1-19.

4. Breast cancer [Internet]. Wikipedia, the free encyclopedia. 2012 [Accessed 14 October 2012]. http://en.wikipedia.org/w/index.php?title=Breast_cancer\&oldid=517603134.

5. Fisher B. From Halsted to prevention and beyond: advances in the management of breast cancer during the twentieth century. Eur. J. Cancer 1999;35:1963-73.

6. Fisher B, Redmond C, Fisher ER, Bauer M, Wolmark N, Wickerham DL, et al. Ten-year results of a randomized clinical trial comparing radical mastectomy and total mastectomy with or without radiation. N. Engl. J. Med 1985;312:674-81.

7. Veronesi U, Saccozzi R, Del Vecchio $M$, Banfi A, Clemente $C$, De Lena $M$, et al. Comparing radical mastectomy with quadrantectomy, axillary dissection, and radiotherapy in patients with small cancers of the breast. N. Engl. J. Med 1981;305:6-11.

8. Cabanas RM. An approach for the treatment of penile carcinoma. Cancer 1977;39:456-66.

9. Giuliano AE, Kirgan DM, Guenther JM, Morton DL. Lymphatic mapping and sentinel lymphadenectomy for breast cancer. Ann. Surg 1994;220:391-8; discussion 398-401.

10. Mansel RE, Fallowfield L, Kissin M, Goyal A, Newcombe RG, Dixon JM, et al. Randomized Multicenter Trial of Sentinel Node Biopsy Versus Standard Axillary Treatment in Operable Breast Cancer: The ALMANAC Trial. J Natl Cancer Inst 2006;98:599-609.

11. Roumen RM, Geuskens LM, Valkenburg JG. In search of the true sentinel node by different injection techniques in breast cancer patients. Eur J Surg Oncol 1999;25:347-51.

12. Roumen RM, Valkenburg JG, Geuskens LM. Lymphoscintigraphy and feasibility of sentinel node biopsy in 83 patients with primary breast cancer. Eur J Surg Oncol 1997;23:495-502.

13. Pepels MJ, Vestjens JHMJ, de Boer M, Smidt M, van Diest PJ, Borm GF, et al. Safety of avoiding routine use of axillary dissection in early stage breast cancer: a systematic review. Breast Cancer Res. Treat 2011;125:301-13.

14. Richtlijn mammacarcinoom 2012. http://www.kwaliteitskoepel.nl/assets/structured-files/2012/ Mammacarcinoom\%202012.pdf. Accessed 2014.

15. Coutant C, Olivier C, Lambaudie E, Fondrinier E, Marchal F, Guillemin F, et al. Comparison of models to predict nonsentinel lymph node status in breast cancer patients with metastatic sentinel lymph nodes: a prospective multicenter study. J. Clin. Oncol 2009;27:2800-8.

16. Dowlatshahi K, Fan M, Snider HC, Habib FA. Lymph node micrometastases from breast carcinoma: reviewing the dilemma. Cancer 1997;80:1188-97.

17. Van Zee KJ, Manasseh D-ME, Bevilacqua JLB, Boolbol SK, Fey JV, Tan LK, et al. A nomogram for predicting the likelihood of additional nodal metastases in breast cancer patients with a positive sentinel node biopsy. Ann. Surg. Oncol 2003;10:1140-51. 



\section{Treatment of 100 patients with sentinel node-negative breast cancer without further axillary dissection}

RMH Roumen, GP Kuijt, IH Liem, MWPM van Beek British Journal of Surgery 2001;88:1639-1643

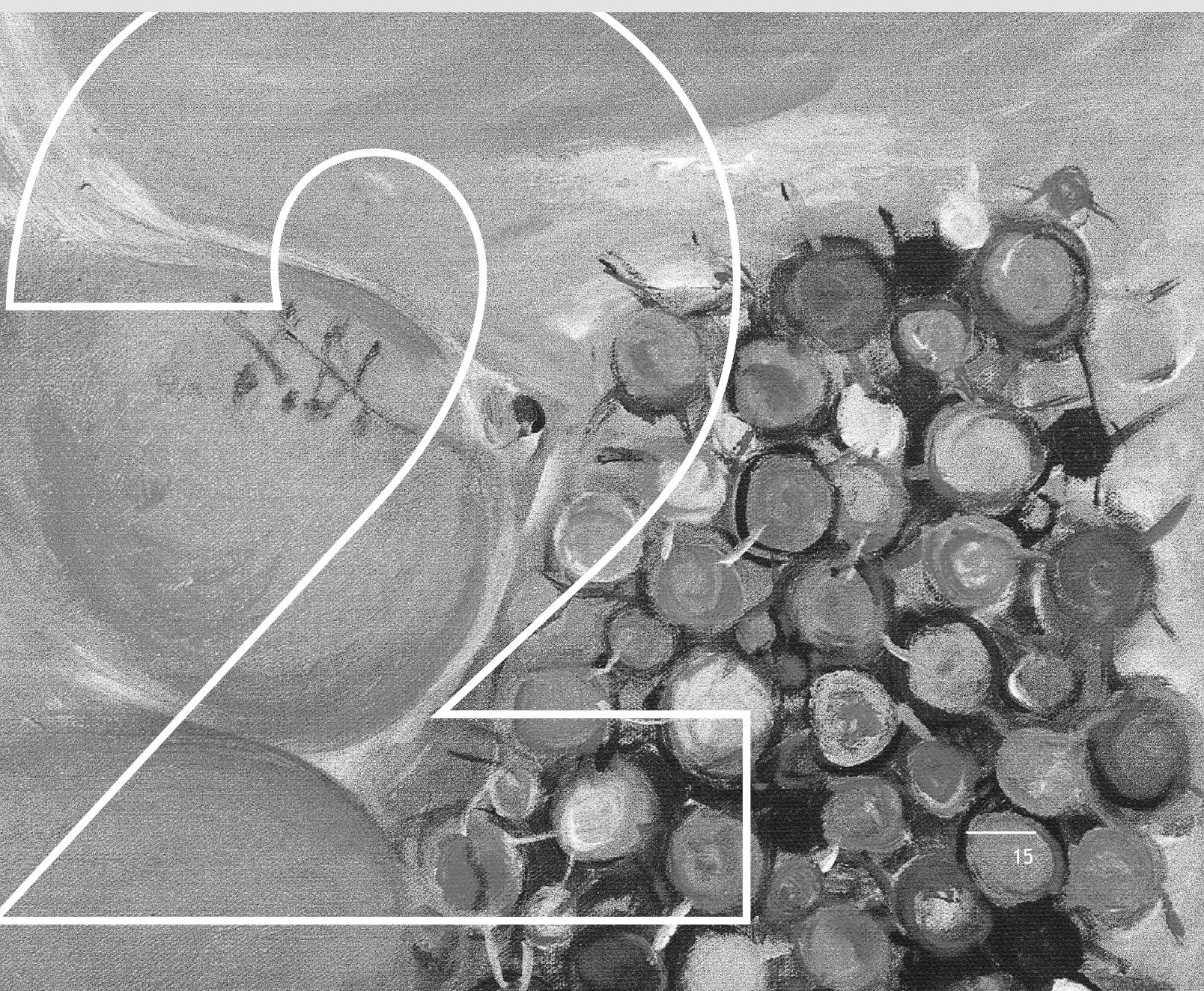




\section{Abstract}

\section{Background}

The sentinel node biopsy technique for breast cancer has been validated extensively in phase I and II studies. However, no data from phase III randomized clinical studies are available. It remains controversial whether a histologically negative sentinel node biopsy without further axillary dissection can be considered to be good clinical practice.

\section{Methods}

One hundred consecutive patients with breast cancer who had a negative sentinel node biopsy without additional axillary dissection were studied prospectively between 1997 and 2000 in order to identify tumour recurrence and to assess the morbidity of the sentinel node procedure. Special attention was paid to axillary or loco regional recurrence, distant metastases and overall survival. One year after the procedure patients were sent a questionnaire to assess any functional impairment of the arm or shoulder.

\section{Results}

Median follow-up was 24 (range 16-40) months. One patient had an axillary relapse 14 months after the initial diagnosis of breast cancer. She died after 2 years from metastatic disease. There were no other local axillary recurrences. There was a $94 \%$ response rate to the questionnaire. Twelve patients developed mild disabilities, of whom two said that they had to change their hobbies, sports or daily activities owing to the sentinel node procedure. No patient developed lymph oedema or needed physiotherapy after the operation.

\section{Conclusion}

When strict criteria for the sentinel node biopsy procedure are used, the sentinel node biopsy without further axillary dissection after a negative histological investigation is a safe procedure. It may therefore be considered to be the standard of care for the treatment of patients with breast cancer. 


\section{Introduction}

In patients with operable primary breast cancer, complete axillary dissection is still considered to be the standard of surgical care. However, the minimally invasive sentinel node biopsy provides an attractive alternative to this procedure, because it reduces morbidity substantially. The main reason for performing a complete axillary dissection in breast cancer is for diagnostic purposes. When the axillary lymph nodes are positive for metastatic disease, adjuvant treatment is necessary, while the complete removal of nodal metastases might be therapeutic and contribute to the surgical cure of the patient. Where axillary nodes are negative, the additional value of a complete dissection of all nodal levels is questioned. Such patients are very unlikely to benefit from complete removal of the axillary lymph nodes.

Until now the sentinel node biopsy only (no additional axillary dissection if the sentinel node is negative for metastatic disease) has been a matter of debate and some authors are opposed to this procedure as the standard of care ${ }^{1,2}$. Their main concern relates to false-negative sentinel node biopsies and their consequences.

The present study provides data about the quality control and regular follow-up of 100 consecutive patients who underwent a sentinel node biopsy as a sole procedure and who did not have an additional complete axillary dissection.

\section{Patients and method}

From the end of 1997 until June 2000, one hundred consecutive patients with operable primary breast cancer, who underwent a sentinel node biopsy that revealed a negative histological status, were studied prospectively. Sentinel node biopsy was performed according to a protocol that included only patients with single tumours less than $3 \mathrm{~cm}$ in diameter, without clinically suspicious palpable axillary nodes and without clinical signs of distant metastases. Patients were informed about the risk and the technique, after which informed consent was obtained. During the interval in question, 143 patients underwent a sentinel node biopsy of which 43 (30\%) were found to be positive.

The biopsy technique has been described previously and includes the use of peritumourally injected technetium-labelled human albumin (Solco R/Nanocoll; Sorin Biomedica Diagnostics, Vercelli, Italy) with lymphoscintigraphy, together with periareolar injection of vital blue dye (Patent Blue V, 2.5\% solution; Laboratoire Guerbet, Aulnay-sous-Bois, France) ${ }^{3,4}$. The sensitivity of this procedure was $95 \%{ }^{3}$. Harvested sentinel nodes were sectioned serially: small nodes (less than $4 \mathrm{~mm}$ ) at three levels and larger nodes at six levels. The slides were then stained with 
haematoxylin and eosin and immunostained with Pan Ab-3 anticytokeratin (Neomarkers, Fremont, California, USA). In the case of a positive sentinel node, patients were offered a complete axillary lymph node dissection. All patients were seen at follow-up after 3 months and subsequently every 6 months. Special attention was paid to possible axillary recurrent disease, locoregional recurrences, distant metastases and new breast cancers.

All patients without recurrent disease or distant metastases were asked to complete a questionnaire assessing postoperative functional disability of the arm and shoulder (Table 2.1). The questionnaires were sent to all patients at least 12 months after the primary surgical procedure.

Table 2.1 Questionnaire responses.

\begin{tabular}{llc}
\hline & & $\begin{array}{c}\text { No. of affirmative } \\
\text { responses }\end{array}$ \\
\hline 1 & Do you have any discomfort as a result of the axillary scar? & $5(6)$ \\
2 & Has the function of your shoulder and/or arm changed since the axillary & $10(11)$ \\
& operation? & $9(10)$ \\
4 & Did you develop a disability in your arm after the axillary operation? & $12(13)$ \\
5 & Do you have any (new) pain in the axilla or shoulder since the operation? & $0(0)$ \\
6 & Has there been a change or loss of sensation in the axilla? & $12(13)$ \\
7 & Did you have to change your hobbies or sports: & $2(2)$ \\
& Due to the operation in the axilla? & $10(11)$ \\
8 & Due to the operation in the axilla? & $0(0)$
\end{tabular}

Values in parentheses are percentages. The questionnaire was sent to all patients without (axillary) recurrence or distant metastases ( $n=96$; response rate $94 \%$ (90 of 96)).

\section{Results}

Table 2.2 shows the initial patient and tumour characteristics of the negative sentinel node biopsy population without further axillary dissection between 1997 and 2000. Median follow-up was 24 (range 16-40) months. During this period, 99 of the 100 patients did not develop a local axillary relapse.

However, one 46-year-old patient was found to have residual axillary disease at 14 months after the initial sentinel node procedure. An excisional biopsy was performed in June 1998, and an invasive ductal carcinoma grade II with a diameter of $8 \mathrm{~mm}$ was diagnosed. The patient then had a sentinel node biopsy (one sentinel node) together with a re-excision of the primary tumour because of a residual ductal carcinoma in situ. In September 1998 an additional mastectomy with primary 
reconstruction using the expander technique was performed. One year later the patient presented with axillary pain and a palpable lesion. A complete axillary dissection showed more than ten positive lymph nodes. Locoregional radiotherapy and hormonal treatment (ovariectomy as well as tamoxifen) was started, but within 2 months the patient developed recurrent disease with pulmonary and bone metastases. In August 2000, 26 months after the initial diagnosis, she died from brain metastases.

Table 2.2 Demographic data of 100 patients with a negative sentinel node biopsy.

\begin{tabular}{|c|c|c|}
\hline Age (years)* & & $59(33-86)$ \\
\hline \multirow{3}{*}{ Menopausal status } & Premenopausal & 33 \\
\hline & Postmenopausal & 66 \\
\hline & Male gender & 1 \\
\hline \multirow[t]{2}{*}{ Type of surgery } & Ablation & 20 \\
\hline & Breast conserving $^{+}$ & 80 \\
\hline Tumour size $(\mathrm{mm})^{*}$ & & $15(3-31)$ \\
\hline \multirow[t]{3}{*}{ Histological grade } & 1 & 42 \\
\hline & ॥ & 23 \\
\hline & III & 35 \\
\hline \multirow[t]{3}{*}{ Histology of tumour } & Ductal & 74 \\
\hline & Lobular & 16 \\
\hline & Mixed or other & 10 \\
\hline \multirow[t]{3}{*}{ Receptor status } & Oestrogen receptor positive & 73 \\
\hline & Progesterone receptor positive & 65 \\
\hline & Unknown & 9 \\
\hline \multirow[t]{2}{*}{ Adjuvant therapy } & Chemotherapy & 13 \\
\hline & Hormonal therapy & 39 \\
\hline \multirow[t]{2}{*}{ Recurrent disease } & Axilla & 1 \\
\hline & Breast/scar & 1 \\
\hline \multirow[t]{3}{*}{ Metastatic disease } & Bone & 1 \\
\hline & Lung & 1 \\
\hline & Lung, bone and brain & 1 \\
\hline \multirow[t]{2}{*}{ Deaths } & Stroke & 1 \\
\hline & Metastatic disease & 2 \\
\hline
\end{tabular}

*Values are median (range). ${ }^{+}$All patients received radiotherapy of the breast; no radiotherapy of the axilla was given. Mean and median number of sentinel node biopsies per patient was 2 (range 1-4).

Another patient, aged 44 years, developed a local recurrence in the skin 9 months after the initial operation, which was a two-stage mastectomy for widespread invasive lobular carcinoma. At that time, no axillary recurrence was found. She was treated with tamoxifen, leading to a partial remission. Four months later a right colectomy was performed because of an invasive colon carcinoma (pT2 NO Mx). Two months after the colectomy, there was an increase in the local mammary skin recurrence and a clinically suspected and pathologically confirmed axillary lymph node had developed. Locoregional radiotherapy was instigated. 
In all, three patients have died: the abovementioned 46-year-old patient from metastatic disease, another 80-year-old patient with bone metastases but without signs of locoregional recurrence, and one 63-year-old patient from a stroke.

Of the 96 patients surviving without residual or recurrent axillary disease, 90 returned the questionnaire (94\% response rate). Table 2.1 shows the responses. Only a minority of the patients complained of mild functional loss or pain in the shoulder or arm. Remarkably none of the patients developed any form of arm oedema or needed additional physiotherapy because of shoulder complaints. Twelve patients experienced some loss of sensation in the axilla, most probably owing to a lesion of the intercostobrachial nerve.

\section{Discussion}

The main purpose of a sentinel node biopsy is to avoid an unnecessary axillary dissection and thus to prevent iatrogenic morbidity. The main criticism of this procedure concerns the consequences of a false-negative biopsy. To date, no randomized controlled phase III clinical trials have been published, while multicentre studies evaluating the method's accuracy compared with complete axillary dissection are still in progress. There is extensive literature available on phase I-II studies that has confirmed the accuracy, feasibility and reliability of the sentinel node procedure ${ }^{5,6}$. There is now a need for quality control and long-term follow-up studies to provide data supporting the sentinel node procedure as an accurate staging method. To date, there are only two studies providing data on patients who had a sentinel lymph node dissection as a sole procedure ${ }^{7,8}$. Both studies, one with a median follow-up of 39 months and the other with less than 2 years' median follow-up, showed no local axillary recurrence in 67 and 285 patients respectively ${ }^{7,8}$. The present series confirms these results.

In their meta-analysis Fraile et al. ${ }^{5}$ concluded that 'due to limitations of axillary lymph node dissection as the golden standard, sentinel node biopsy can in fact be considered a more accurate method for nodal staging'. Based on extensive reviews and metaanalyses of most of the existing phase I and II studies, the false-negative rate of the sentinel node biopsy (including completion axillary dissection) in breast cancer has been shown to vary between $0 \%$ and $17 \%$, with a mean of $8-9 \%$ (95\% confidence interval $7-11 \%)^{5,6}$.

The sensitivity for the present patient population should have been least as high as a previously shown value of $95 \%{ }^{3}$ because of the authors' tendency to perform an ultrasonographic investigation (with fine-needle aspiration) of the axilla when there are palpable axillary nodes ${ }^{9}$. By this means, patients with positive axillary nodes are 
selected who can be excluded from the sentinel node biopsy procedure. This policy, incorporated in 1998, may reduce the false-negative rate and could be the reason why in the present series of 143 patients the positive nodal rate $(30 \%)$ was less than that published previously $(37 \%)^{3}$.

A 95\% sensitivity of the sentinel node procedure means that the expected number of patients with residual nodal involvement after a negative sentinel node biopsy without further axillary dissection is $3 \%$, when the a priori chance of a positive node is 40\%. Considering 1000 patients with breast cancer, 400 patients will be truly node positive while 600 will be truly node negative. Assuming a 95\% sensitivity, 20 of the 400 patients will not be discovered as being node positive and will wrongly be put in the group of 600 true-negative patients. Thus, of the 620 sentinel node-negative patients, 20 will be falsely negative. Therefore, with a sensitivity of $95 \%$, only $3 \%(20$ of 620 ) of the patients thought to be negative are truly node positive. When the a priori number of true node-positive patients is smaller, then the number of false negatives will also be smaller.

The present study shows that, after a median follow-up of 24 months, only one patient had axillary residual nodal disease, although this case had a disastrous outcome. Recently, de Boer et al. ${ }^{10}$ showed that axillary recurrence after complete axillary dissection for invasive breast cancer occurred in 59 (1\%) of 4669 patients at a median interval of 2.6 years. From the NSABP-04 study it is known that three-quarters of patients with breast cancer develop their axillary recurrence within 2 years ${ }^{11}$.

Based on the calculations above, approximately three of the 100 patients would be expected to become positive for axillary residual disease at some time. Fortunately, the present data are better than expected. This may be due to adjuvant treatment, which was given to half of the patients $(n=52)$ based on tumour-related factors according to recent guidelines ${ }^{12,13}$, because of the policy of detection of positive axillary nodes by ultrasonography and fine-needle aspiration, or simply because the follow-up period is still too short.

On the other hand, from previous studies it is known that about $20 \%$ of patients with breast cancer who receive no treatment of the axilla will develop an axillary relapse ${ }^{11}$. When the incidence of true-positive axillary nodal metastases is about $40 \%$, why then is the relapse rate only $20 \%$ after even 10 years of follow-up? Possible explanations for this include the role of the biological behaviour of the tumour, the systemic adjuvant treatment given, the type of surgery and (local) breast radiation ${ }^{2,7}$.

The patient questionnaire showed that the morbidity of the sentinel node biopsy procedure is minor. Only a few patients described pain in the axillary scar, or numbness or paraesthesia of the skin. None of the patients developed oedema and 
only two patients responded that they had to change their hobbies or sports because of the operation in the axilla. After a complete axillary dissection, 30\% of patients have some kind of disabling pain, $10-30 \%$ develop arm oedema, up to $70 \%$ have numbness and $30 \%$ have some form of functional impairment ${ }^{14-16}$. In a recent study it was shown that more than $30 \%$ of the patients needed physiotherapy after the axillary operation compared with none in the present group ${ }^{17}$.

The key question that remains is whether or not it is acceptable to have one fatal recurrence of local axillary disease while avoiding 99 unnecessary axillary dissections. Reflecting on this, one should keep in mind the indications for adjuvant chemotherapy according to recent guidelines: a given therapy with its morbidity should be advised only when an absolute 10 -year survival benefit of $5 \%$ can be gained ${ }^{12,13}$. Implicitly, this means that it is thought acceptable not to treat 96 patients unnecessarily with chemotherapy if there are four or fewer 10-year survivors to be gained.

It is concluded that when strict criteria for the sentinel node procedure are adhered to, a negative histopathological sentinel node biopsy without further axillary dissection is a correct part of good clinical practice in the treatment of patients with breast cancer and may thus be considered to be the standard of care. 


\section{References}

1. McMasters KM, Giuliano AE, Ross MI, Reintgen DS, Hunt KK, Byrd DR et al. Sentinel-lymph-node biopsy for breast cancer - not yet the standard of care. N Engl J Med 1998; 339:990-5.

2. Spillane AJ, Sacks NPM. Role of axillary surgery in early breast cancer: review of the current evidence. Aust N Z J Surg 2000;70: 515-24.

3. Roumen RMH, Valkenburg JGM, Geuskens LM. Lymphoscintigraphy and feasibility of sentinel node biopsy in 83 patients with primary breast cancer. Eur J Surg Oncol 1997;23: 495-502.

4. Borgstein PJ, Meijer S, Pijpers R. Intradermal blue dye to identify sentinel lymph-node in breast cancer. Lancet 1997;349: 1668-9.

5. Fraile M, Rull M, Julian FJ, Fuste F, Barnadas A, Llatjos M et al. Sentinel node biopsy as a practical alternative to axillary lymph node dissection in breast cancer patients: an approach to its validity. Ann Oncol 2000; 11: 701-5.

6. Sandrucci S, Casalegno PS, Percivale P, Mistrangelo M, Bombardieri E, Bertoglio S. Sentinel lymph node mapping and biopsy for breast cancer: a review of the literature relative to 4791 procedures. Tumori 1999; 85: 425-34.

7. Giuliano AE, Haigh PI, Brennan MB, Hansen NM, Kelley MC, Ye W et al. Prospective observational study of sentinel lymphadenectomy without further axillary dissection in patients with sentinel nodenegative breast cancer. J Clin Oncol 2000; 18: 2553-9.

8. Veronesi U, Galimberti V, Zurrida S, Pigatto F, Veronesi P, Robertson C et al. Sentinel lymph node biopsy as an indicator for axillary dissection in early breast cancer. Eur J Cancer 2001;37: 454-8.

9. Bonnema J, van Geel AN, van Ooijen B, Mali SP, Tjiam SL, Henzen-Logmans SC et al. Ultrasoundguided aspiration biopsy for detection of nonpalpable axillary node metastases in breast cancer patients: new diagnostic method. World J Surg 1997; 21: 270-4.

10. de Boer R, Hillen HFP, Roumen RMH, Rutten HJT, van der Sangen MJC, Voogd AC. Detection, treatment and outcome of axillary recurrence after axillary clearance for invasive breast cancer. $\mathrm{Br} \mathrm{J}$ Surg 2001; 88: 118-22.

11. Fisher B, Redmond C, Fisher ER, Bauer M, Wolmark N, Wickerham DL et al. Ten-year results of a randomized clinical trial comparing radical mastectomy and total mastectomy with or without radiation. N Engl J Med 1985; 312: 674-81.

12. Bontenbal M, Nortier JWR, Beex LVAM, Bakker P, Hupperets PSGJ, Nooij MA et al. Adjuvant systemic therapy for patients with resectable breast cancer: guideline from the Dutch National Breast Cancer Platform and the Dutch Society for Medical Oncology. Ned Tijdschr Geneeskd 2000; 144: 984-9.

13. Steering Committee on Clinical Practice Guidelines for the Care and Treatment of Breast Cancer. Adjuvant systemic therapy for women with node-negative breast cancer. CMAJ 1998; 158(Suppl 3): s43-51.

14. Liljegren G, Holmberg L. Arm morbidity after sector resection and axillary dissection with or without postoperative radiotherapy in breast cancer stage I. Results from a randomised trial. Uppsala-Orebro Breast Cancer Study Group. Eur J Cancer 1997; 33: 193-9.

15. Ivens D, Hoe AL, Podd TJ, Hamilton CR, Taylor I, Royle GT. Assessment of morbidity from complete axillary dissection. Br J Cancer 1992; 66: 136-8.

16. Hack TF, Cohen L, Katz J, Robson LS, Goss P. Physical and psychological morbidity after axillary lymph node dissection for breast cancer. J Clin Oncol 1999; 17: 143-9.

17. Dons IPM, Stiegelis HE, Voogd AC, Coebergh JWW, Crommelin MA, Roumen RMH et al. Kwaliteit van leven na okselklierdissectie bij patienten met mammacarcinoom. Ned Tijdschr Heelkd 1998; 7: 18994. 



\section{Survival after negative sentinel lymph node biopsy in breast cancer at least equivalent to after negative extensive axillary dissection}

GP Kuijt, LV van de Poll-Franse, AC Voogd, GAP Nieuwenhuijzen, RMH Roumen European Journal of Surgical Oncology 2007;33:832-837

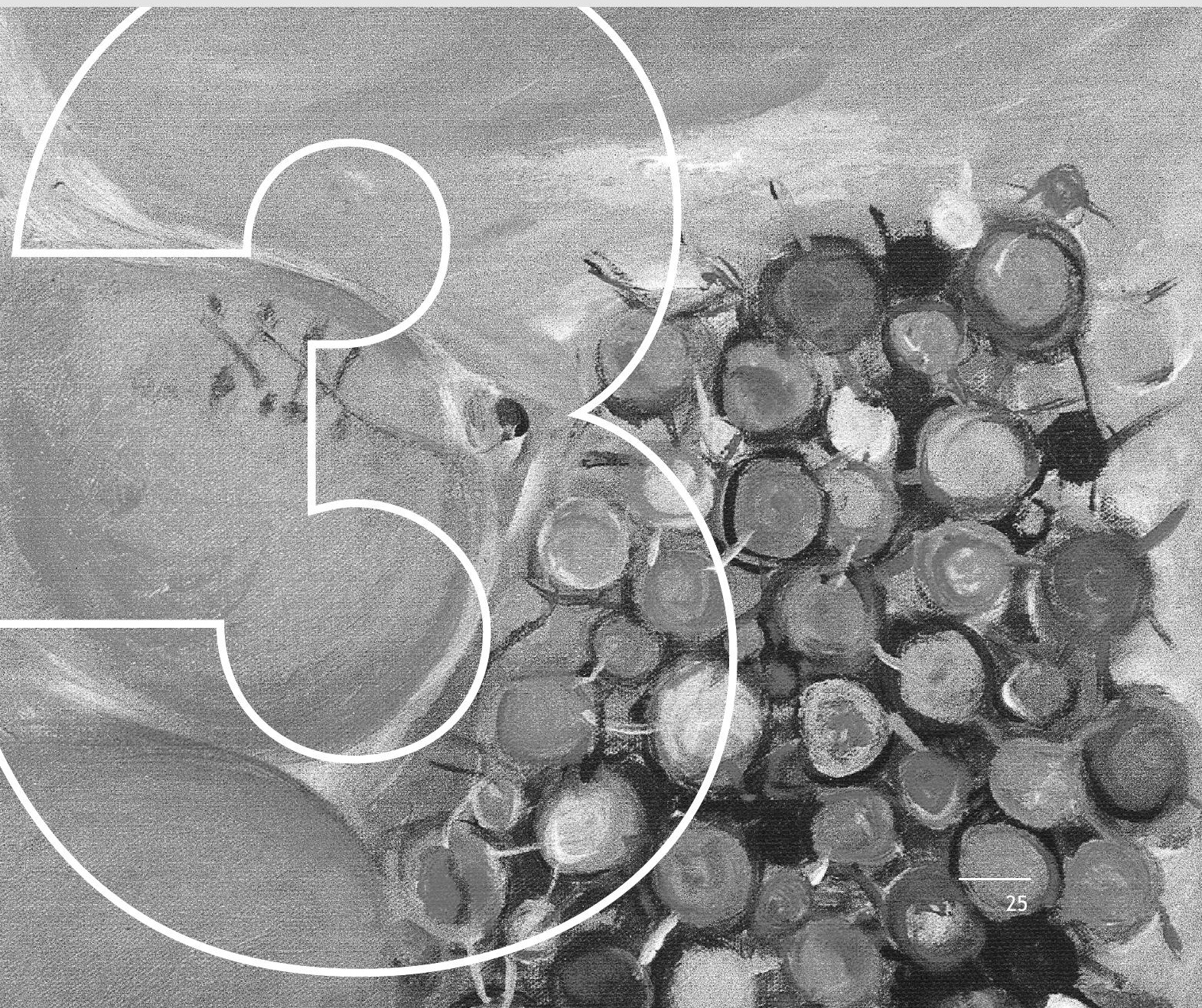




\section{Abstract}

Aim

Sentinel lymph node biopsy (SLNB) without completion axillary lymph node dissection (ALND) is replacing ALND as the axillary staging procedure of choice in breast cancer patients with a clinically negative axilla even though it is unclear whether this influences patient survival. Our aim was to compare the survival of breast cancer patients with a negative SLNB without completion ALND to that of extensive ALNDnegative patients.

Methods

Eindhoven Cancer Registry data on breast cancer patients diagnosed between 1989 and 2002 with follow-up to 1 January 2005 was used. Survival was compared between 880 SLNB-negative women (median follow-up 3.6 years) without completion ALND and 1681 ALND-negative women (median follow-up 7.7 years) with at least 10 axillary nodes removed. Conclusions were made after correcting for age, tumour size, tumour location, tumour histology, tumour grade, mitotic activity index (MAl), hormone receptor status, and local and systemic treatment in uni- and multivariate analyses.

\section{Results}

Crude 5-year survival rates were $85 \%$ for ALND-negative and $89 \%$ for SLNB-negative breast cancer patients $(p=0.026)$. After correction for potential confounders in a multivariate Cox regression analyses, the hazard ratio for overall mortality of ALNDnegative compared to SLNB-negative patients without completion ALND was 1.23 (95\% confidence interval: 0.93-1.64).

\section{Conclusion}

Survival after a SLNB without completion ALND is at least equivalent to after an extensive ALND in node-negative breast cancer patients. This means that the SLNB only can safely replace ALND as the procedure of choice for axillary staging in breast cancer patients with a clinically negative axilla. 


\section{Introduction}

The axillary lymph node status has independent prognostic value in staging breast cancer patients ${ }^{1}$. During the past decade, a paradigm shift has occurred in axillary staging, from a standard complete axillary lymph node dissection (ALND) for every patient with breast cancer to a sentinel lymph node biopsy (SLNB) in the group of patients with a clinically negative axilla. This change has been motivated by the high morbidity of the ALND procedure ${ }^{2-4}$.

The sentinel node is defined as "the first lymph node to receive lymphatic drainage from a primary tumour" ${ }^{\prime 5}$. If this sentinel lymph node, sometimes physically consisting of more than one lymph node, contains no metastatic tumour, then it is unlikely other lymph nodes will contain metastasis ${ }^{5}$. In breast cancer this means that when a SLNB contains no metastasis, it is unnecessary to perform a completion ALND.

When the SLNB does contain metastasis, a completion ALND is recommended in order to further stage the axilla and to maintain local control. A false-negative SLNB procedure will result in omitting an ALND and possibly in under staging the disease, then resulting in the withholding of adjuvant systemic therapy and inferior prognosis.

To avoid false-negative procedures, the introduction of the SLNB has been accompanied by multiple validation studies. Initial studies focused on feasibility issues including performing a completion ALND after SLNB in a single session as proof of performance ${ }^{6}$. More recently SLNB-negative patient series reporting axillary recurrence have been published ${ }^{7-10}$. These studies show that the SLNB is reliable in detecting axillary metastasis and that it has a low axillary recurrence rate. Before SLNB is completely accepted as the procedure of choice in the staging of clinically nodenegative breast cancer patients, survival after both procedures must be compared, especially since a meta-analysis has shown that ALND in itself increases survival in clinically node-negative breast cancer patients ${ }^{11}$.

The aim of this study was to confirm the validity of the SLNB by comparing the survival rate of breast cancer patients with negative lymph node following SLNB without completion ALND to the survival rate of breast cancer patients with negative lymph nodes following an extensive ALND. The hypothesis is that survival following a SLNB is at least equivalent to survival following an adequate ALND. This would constitute definitive evidence that the SLNB can safely replace ALND as the gold standard for axillary staging in breast cancer patients with a clinically negative axilla. 


\section{Patients and method}

\section{Patient selection}

Patient data were retrieved from the Eastern area of the population-based Eindhoven Cancer Registry ${ }^{12}$ serving a population of one million inhabitants in the south-eastern Netherlands. Trained registry clerks collected data from hospital records in 10 hospitals, consisting of large non-university teaching hospitals as well as community hospitals, and from two radiotherapy departments. Collected data is continually internally monitored for completeness and accuracy ${ }^{12}$.

Patients were selected from those registered with breast cancer in the period 19892002. A SLNB group was defined as those patients having undergone a negative SLNB without further ALND. The ALND group was defined as those patients having undergone a negative ALND where 10 or more lymph nodes were found at pathological investigation. The choice of defining an extensive ALND as containing 10 or more lymph nodes was made to minimize the risk of erroneous classification of the axilla $^{13,14}$

\section{Treatment guidelines}

The regional Breast Cancer Study Group has been responsible for the development of multidisciplinary guidelines for the management of breast cancer since 1978.

Surgical treatment during the study period consisted of primary tumour resection via lumpectomy or mammary ablation as well as axillary staging. Complete axillary dissection was recommended for all patients with resectable breast cancer. The borders of the dissection were the latissimus dorsi muscle (dorsal), the thoracic wall (medial), the pectoral muscles (ventral), and the lower border of the axillary vein (cranial). The SLNB was introduced in the registry region in 1995, starting with validation studies including subsequent axillary dissection ${ }^{6}$. In 1997 , surgeons in three of the 10 hospitals started performing SLNB procedures in clinically node-negative patients as a routine staging procedure without completion ALND in cases with a negative sentinel node, and since 2002 it has been routinely performed in all hospitals. Lymphatic mapping included the use of both radioactive lymphoscintigraphy and blue dye $\mathrm{e}^{15}$.

The axillary lymph nodes in the ALND group were evaluated histologically with haematoxylin and eosin (H\&E) stains of one or two sections. Analysis of the sentinel lymph nodes additionally included serial sectioning and immuno-histochemical staining if no metastasis was found on the H\&E stain. All patients were staged according to the Tumour-Node-Metastasis (TNM) classification system of the International Union Against Cancer. 
Until 2000, adjuvant hormone or chemotherapy treatment was only recommended for axillary node-positive patients. Since 2000, guidelines have evolved to also recommend systemic treatment to selective node-negative patients depending on additional factors other than the lymph node status, such as the size and the histological grade of the tumour and the steroid receptor status ${ }^{16}$. In the present study population of lymph node-negative breast cancer patients, radiotherapy was mostly applied to the breast in the context of breast conserving treatment although sporadically other indications existed.

\section{Data available for analysis}

The following data for each patient were available for analysis: period of diagnosis, age at diagnosis, tumour size defined at pathological evaluation, tumour location, tumour histology, tumour grade, mitotic activity index (MAI), oestrogen and progesterone receptor status, treatment of the primary tumour, and whether or not systemic therapy was administered. The MAI is a standardized method of assessing the mitotic count of a tumour and is defined as the sum of mitoses in 10 high-power microscope fields, equivalent to a surface area of $1.59 \mathrm{~mm}^{2}$ at the periphery of the tumour $^{17}$. The mitotic count is considered the most predictive component of the histological grade.

Follow-up was completed through January 1, 2005, and was obtained from municipal registries and the Central Bureau for Genealogy. The latter is an institution that collects data on all deceased Dutch citizens via all municipal registries. This way, information on patients who had moved outside the registry area was also obtained. Patients who died outside the Netherlands were wrongly considered as "being alive". The estimated proportion of these patients was approximately $0.3 \%$.

\section{Statistical analysis}

Statistical analyses were performed using SAS (version 9.1 for Windows, SAS institute Inc., Cary, NC). Differences in patient characteristics between those with SLNB without completion ALND and those with ALND were tested by means of chi-square statistics. Survival analysis was carried out using the Kaplan-Meier method to evaluate the prognosis after the diagnosis of breast cancer. Survival time was defined as the period between the date of diagnosis and the date of death or last follow-up. Patients with incomplete follow-up were censored at the date of last follow-up. The overall survival of patients with node-negative breast cancer following a sentinel node procedure was compared with the survival rates of patients with 10 or more tumour-negative lymph nodes following axillary lymph node dissection. The survival curves were compared by means of the two-tailed log-rank test. 
Univariate analysis were performed to assess the relationship of overall survival to the following variables: axillary staging procedure, period of diagnosis, age at diagnosis, tumour size, tumour location, tumour histology, tumour grade, MAI, oestrogen and progesterone receptor status, tumour treatment, and whether or not systemic therapy was given.

Multivariate Cox proportional hazards regression analyses were carried out to adjust for potential confounding effects. Co-variates found to be significant in the univariate analysis were analyzed with respect to the relationship between mortality risk and the axillary staging procedure performed. Period of diagnosis was excluded in the multi-variate analysis because it was estimated that including period of diagnosis would overcorrect for the variable "axillary staging procedure". Hazard ratios (HR) with $95 \%$ confidence intervals $(95 \% \mathrm{Cl})$ and $p$ values were estimated with respect to the reference category for each covariate.

\section{Results}

There were 7974 patients documented as having had breast cancer between 1989 and 2002. This study compared the 880 of these patients having undergone a SNLB procedure without completion ALND to the 1681 patients having undergone an ALND where 10 or more lymph nodes were found at pathological examination. The remaining patients were excluded: 2869 were node positive; 754 lacked information on the number of lymph nodes; and 1790 patients were reported as having less than 10 lymph nodes found at pathological examination.

Demographic and clinical characteristics are presented in Table 3.1. Age at diagnosis and tumour histology was comparable in both groups while all other parameters were significantly different. The patients who underwent SLNB without completion ALND were more likely to have small tumours, laterally located tumours, well differentiated tumours and hormone receptor positive tumours, and were more likely to have had breast conserving treatment and systemic therapy than the patients in the ALND group.

Crude 5-year survival rates were $85 \%$ for ALND-negative and $89 \%$ for SLNB-negative breast cancer patients ( $p=0.026)$ (Figure 3.1). 
Table 3.1 General characteristics of patients with lymph node-negative breast cancer according to number of lymph nodes $(n=2561)$.

\begin{tabular}{|c|c|c|c|}
\hline & \multicolumn{2}{|c|}{ Axillary staging procedure } & \multirow{3}{*}{$\begin{array}{l}\chi^{2} \text {-test } \\
P \text { value }\end{array}$} \\
\hline & SLNB & ALND, $\geq 10$ nodes examined & \\
\hline & $n=880$ & $n=1681$ & \\
\hline \multicolumn{4}{|l|}{ Period of diagnosis } \\
\hline 1989-1993 & 0 & 487 & \\
\hline 1994-1998 & 64 & 889 & \\
\hline 1999-2002 & 816 & 305 & $<0.0001$ \\
\hline \multicolumn{4}{|l|}{ Age (years) } \\
\hline$<50$ & 219 & 439 & \\
\hline $50-69$ & 470 & 859 & \\
\hline $70^{+}$ & 191 & 383 & 0.54 \\
\hline \multicolumn{4}{|l|}{ Tumour size (pT) } \\
\hline $\mathrm{T} 1$ & 671 & 1077 & \\
\hline $\mathrm{T} 2$ & 178 & 480 & \\
\hline T3 & 4 & 21 & \\
\hline $\mathrm{T} 4$ & 13 & 51 & \\
\hline Unknown & 14 & 52 & $<0.0001$ \\
\hline \multicolumn{4}{|l|}{ Tumour location } \\
\hline Lateral & 451 & 774 & \\
\hline Medial/central & 219 & 442 & \\
\hline Overlapping & 186 & 431 & \\
\hline Missing & 24 & 34 & 0.02 \\
\hline \multicolumn{4}{|l|}{ Tumour histology } \\
\hline Ductal & 654 & 1252 & \\
\hline Lobular mixed & 158 & 296 & \\
\hline Mucinous & 49 & 110 & \\
\hline Other & 19 & 23 & 0.37 \\
\hline \multicolumn{4}{|l|}{ Tumour grade } \\
\hline 1 & 166 & 137 & \\
\hline 2 & 224 & 360 & \\
\hline 3 & 142 & 251 & \\
\hline Missing & 348 & 933 & $<0.0001$ \\
\hline \multicolumn{4}{|l|}{ MAI } \\
\hline$<10$ & 608 & 354 & \\
\hline$\geq 10$ & 149 & 147 & \\
\hline Missing & 123 & 1180 & $<0.0001$ \\
\hline \multicolumn{4}{|l|}{ ER } \\
\hline Positive & 610 & 849 & \\
\hline Negative & 122 & 297 & \\
\hline Missing & 148 & 535 & $<0.0001$ \\
\hline \multicolumn{4}{|l|}{ PR } \\
\hline Positive & 471 & 625 & \\
\hline Negative & 156 & 331 & \\
\hline Missing & 253 & 725 & $<0.0001$ \\
\hline \multicolumn{4}{|l|}{ Tumour treatment } \\
\hline $\mathrm{BCS}+\mathrm{RT}$ & 697 & 938 & \\
\hline $\mathrm{BCS}-\mathrm{RT}$ & 41 & 33 & \\
\hline Mastectomy - RT & 131 & 583 & \\
\hline Other & 11 & 127 & $<0.0001$ \\
\hline \multicolumn{4}{|l|}{ Systemic therapy } \\
\hline No & 661 & 1531 & \\
\hline Yes & 219 & 150 & $<0.0001$ \\
\hline
\end{tabular}

$\mathrm{MAI}$, mitotic activity index; $\mathrm{ER}$, oestrogen receptor; $\mathrm{PR}$, progesterone receptor; $\mathrm{BCS}$, breast conserving surgery; RT, radiotherapy. 
Univariate analysis showed a significant survival disadvantage for the ALND group compared to the SLNB with out completion ALND group, hazard ratio $1.37(95 \% \mathrm{Cl}$ : 1.04-1.80) (Table 3.2). Other variables in univariate analysis significantly associated with an increased hazard ratio were the earlier periods of diagnosis, older age (70+) at diagnosis, increasing tumour size, higher tumour grade, mucinous tumour histology, and not having had radiotherapy.

After adjustment for age, tumour size, tumour histology, tumour grade, and local tumour treatment in multivariate Cox-regression analyses, the hazard ratio for ALND-negative versus SLNB-negative patient without completion ALND was: 1.23 (95\% Cl:0.93-1.64) (Table 3.2). Other variables independently associated with an increased hazard ratio were age at diagnosis (70+ vs. <50: $\mathrm{HR} 3.18 ; \mathrm{Cl} 2.45-4.11$ ), tumour size (>2-5 cm vs. $\leq 2 \mathrm{~cm}$ : HR 1.47; $\mathrm{Cl} 1.20-1.80$ ), tumour grade (poorly vs. well differentiated: $\mathrm{HR} 1.74 ; \mathrm{Cl} 1.14-2.67)$, and breast conserving treatment without versus with radiotherapy (HR 1.74; $\mathrm{Cl}$ 1.03-2.95) (Table 3.2).

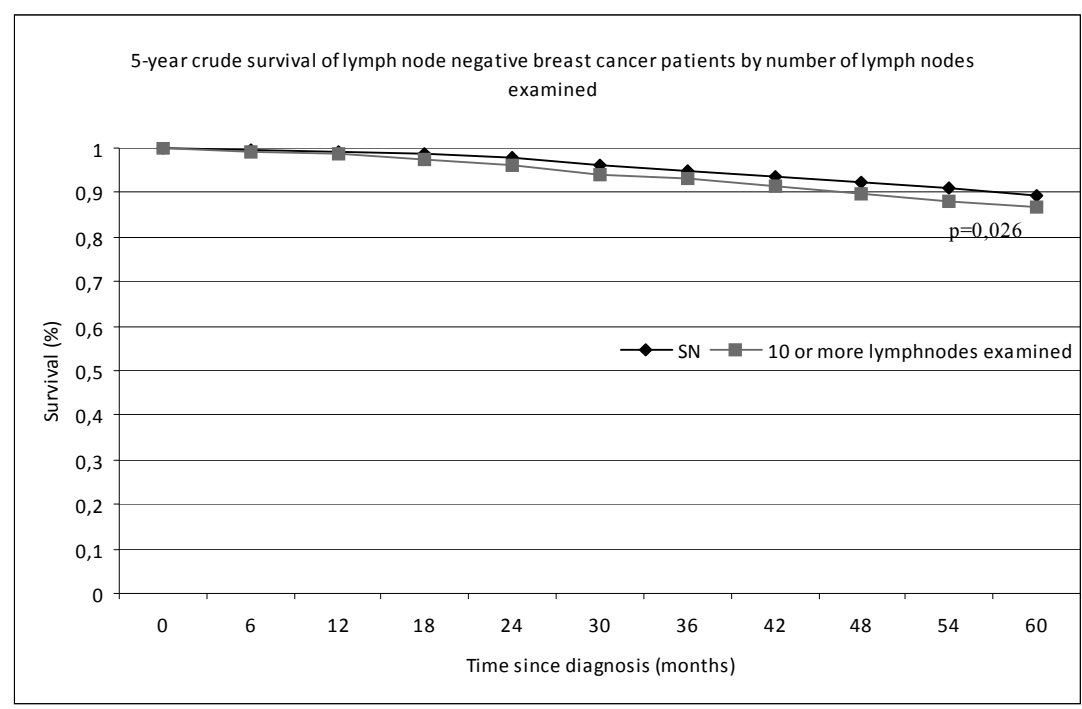

Figure 3.1 Overall survival of lymph node negative breast cancer patients according to either SN procedure or 10 or more lymph nodes examined. 
Table 3.2 Multivariate analyses of overall survival in lymph node negative breast cancer patients $(n=2561)$.

\begin{tabular}{|c|c|c|c|c|}
\hline & \multicolumn{2}{|c|}{ Univariate } & \multicolumn{2}{|c|}{ Multivariate $\underline{a}$} \\
\hline & $\mathrm{HR}$ & $(95 \% \mathrm{Cl})$ & $\mathrm{HR}$ & $(95 \% \mathrm{Cl})$ \\
\hline \multicolumn{5}{|c|}{ Axillary staging procedure } \\
\hline SLNB & 1 & & 1 & \\
\hline$\geq 10$ nodes examined & 1.37 & $(1.04-1.80)^{*}$ & 1.23 & (0.93-1.64) \\
\hline \multicolumn{5}{|l|}{ Period } \\
\hline 1989-1993 & 1 & & & \\
\hline 1994-1998 & 0.79 & $(0.63-0.98)^{*}$ & & \\
\hline 1999-2002 & 0.75 & $(0.57-0.99)^{*}$ & & \\
\hline \multicolumn{5}{|l|}{ Age (years) } \\
\hline$<50$ & 1 & & 1 & \\
\hline $50-69$ & 0.95 & $(0.74-1.22)$ & 0.98 & $(0.76-1.27)$ \\
\hline $70+$ & 3.28 & $(2.56-4.21)^{* *}$ & 3.18 & $(2.45-4.11)^{* *}$ \\
\hline \multicolumn{5}{|l|}{ Tumour size (pT) } \\
\hline $\mathrm{T} 1$ & 1 & & 1 & \\
\hline $\mathrm{T} 2$ & 1.79 & $(1.48-2.18)^{* *}$ & 1.47 & $(1.20-1.80)^{*}$ \\
\hline T3 & 1.78 & $(0.84-3.76)$ & 2.04 & $(0.94-4.47)$ \\
\hline $\mathrm{T} 4$ & 2.04 & $(1.31-3.19)^{*}$ & 1.57 & $(0.95-2.58)$ \\
\hline \multicolumn{5}{|l|}{ Tumour location } \\
\hline Lateral & 1 & & & \\
\hline Medial/central & 1.23 & $(0.99-1.53)$ & & \\
\hline Overlapping & 1.14 & (0.91-1.43) & & \\
\hline \multicolumn{5}{|l|}{ Tumour grade } \\
\hline 1 & 1 & & 1 & \\
\hline 2 & 1.28 & $(0.86-1.93)$ & 1.28 & $(0.85-1.93)$ \\
\hline 3 & 1.57 & $(1.04-2.38)^{*}$ & 1.74 & $(1.14-2.67)^{*}$ \\
\hline \multicolumn{5}{|l|}{ MAI } \\
\hline$<10$ & 1 & & & \\
\hline$\geq 10$ & 1.37 & $(0.94-2.00)$ & & \\
\hline \multicolumn{5}{|l|}{ Tumour histology } \\
\hline Ductal & 1 & & 1 & \\
\hline Lobular mixed & 0.92 & $(0.72-1.17)$ & 0.81 & $(0.63-1.05)$ \\
\hline Mucinous & 0.56 & $(0.35-0.90)^{*}$ & 0.64 & $(0.40-1.04)$ \\
\hline \multicolumn{5}{|l|}{ ER } \\
\hline Negative & 1 & & & \\
\hline Positive & 1.02 & (0.79-1.30) & & \\
\hline \multicolumn{5}{|l|}{ PR } \\
\hline Negative & 1 & & & \\
\hline Positive & 0.81 & $(0.64-1.03)$ & & \\
\hline \multicolumn{5}{|l|}{ Tumour treatment } \\
\hline $\mathrm{BCS}+\mathrm{RT}$ & 1 & & 1 & \\
\hline BCS-RT & 1.87 & $(1.11-3.14)^{*}$ & 1.74 & $(1.03-2.95)^{*}$ \\
\hline Mastectomy-RT & 1.70 & $(1.40-2.07)^{* *}$ & 1.19 & $(0.96-1.47)$ \\
\hline Other & 1.59 & $(1.13-2.24)^{*}$ & 0.99 & $(0.67-1.47)$ \\
\hline \multicolumn{5}{|l|}{ Systemic therapy } \\
\hline No & 1 & & & \\
\hline Yes & 1.16 & $(0.85-1.58)$ & & \\
\hline
\end{tabular}

$\mathrm{HR}$, hazard ratio; MAI, mitotic activity index; ER, oestrogen receptor; PR, progesterone receptor; BCS, breast conserving surgery; $\mathrm{RT}$, radiotherapy. ${ }^{*} \mathrm{p}<0.05 ;{ }^{* *} \mathrm{p}<0.0001$; a In the multivariate model, all variables were included that showed a significant univariate association. Period was not included in the model as this was thought to result in an overcorrection of the variable of interest. 


\section{Discussion}

\section{Main message}

In this population-based study, the overall survival of breast cancer patients undergoing SLNB without completion ALND was better than that of patients undergoing an extensive ALND where at least 10 lymph nodes were removed. However, this survival advantage disappeared after accounting for known prognostic factors in multivariate analysis. The conclusion is that survival was similar between the two groups.

The introduction of a new procedure in medicine is rightly only accepted after proof that it works and that it is safe to use it. That the SLNB procedure, including lymphatic mapping, surgery, and pathological analysis, works in detecting axillary lymph node metastasis has been well evaluated ${ }^{18}$. That it does not influence survival without a completion ALND has not yet been proven. Ideally, proof of safety of the SLNB in staging the axilla in breast cancer patients should be determined in a controlled randomized trial comparing the SLNB without completion ALND to the ALND with survival as endpoint. Such studies are running but are not yet completed ${ }^{4}$. In the meantime, this study made use of the large body of outcome data in the Eindhoven Cancer Registry to answer this question, compensating for potential bias in a multivariate analysis.

\section{Possible bias and confounding}

Patient selection in this population-based study is a possible source of bias. Out of the 7974 patients registered as having breast cancer between 1989-2002, 754 had no information on their axillary status, 434 reported zero lymph nodes found, and 1356 reported less than 10 lymph nodes found. Analysis of these sub-groups showed that these were primarily older patients in the earlier periods of this study. In very elderly patients it was customary to do only a limited ALND or even no ALND because it was thought they would not live long enough to profit from an extensive ALND. A multivariate analysis using only the patients from the most recent period 1999-2002, with many less missing values, did not significantly change the results. The hazard ratio of ALND versus SLNB without completion ALND for the period 1999-2002 was 1.02 ( $\mathrm{Cl} 0.69-1.51)$. This means that these missing values do not essentially change the results found in this study.

Tumour grade is well recognized as having strong prognostic value, and this study has many missing values for this parameter. Because of problems with uniformity and reproducibility of tumour differentiation grade, it was accepted practice during the period included in this study in the Netherlands for pathologists to report either the Bloom Richardson grade or the Mitotic Activity Index (MAI) or both. In order to reduce 
the number of missing values for this parameter, a separate analysis was done combining the Bloom Richardson grade with the MAl as a measure for tumour differentiation grade. When known, the Bloom Richardson grade was used and if unknown, then MAI was used with MAl greater or equal to 10 treated as tumour grade three and MAI less than 10 treated as tumour grade one ${ }^{17,19}$. This reduced the missing values to $7 \%$ in the SLNB group and $44 \%$ in the ALND group. This only marginally changed the hazard ratio for tumour grade, from $1.74(\mathrm{Cl}: 1.14-2.67)$ when analysing tumour grade and MAI separately to $1.57(\mathrm{Cl}: 1.13-2.18)$ when combining MAI with the tumour grade. This study presents the results separately so that readers can form their own opinion. It was outside the scope of this study to form conclusions about the nature and the strength of the relationship between MAI and tumour grade.

There was a significant difference in the distribution of tumour size and grade between the SNLB and ALND groups, as well as differences in local tumour treatment and the administration of systemic therapy. The SLNB group included more patients with small tumours and well differentiated tumours, as well as more patients undergoing breast conserving treatment and receiving systemic treatment. A subanalysis of these phenomena showed that this is primarily explained by the period in which the patient was diagnosed with breast cancer. Initial treatment guidelines advised against the use of SLNB in patients with tumours larger than $2 \mathrm{~cm}$ in diameter, with more than one primary tumour, and with a clinically positive axilla ${ }^{20}$. Also, guidelines evolved over time to recommend hormone therapy and chemotherapy to selected node-negative patients ${ }^{16}$. This is why this study did not include period of diagnosis as a separate parameter in the multivariate analysis. It would have overcompensated for recognized differences in tumour size, tumour grade, tumour treatment, and the administration of systemic treatment between the two groups as described above.

\section{Conclusion}

The introduction of the SLNB for staging the axilla rightly raised concerns about its feasibility, safety and accuracy. The results of this population-based study show that, after correction for known prognostic variables, breast cancer patients with a negative SLNB without completion ALND had survival similar to ALND-negative patients who had 10 or more axillary nodes examined. ALND therefore has no independent survival benefit in node-negative breast cancer patients, meaning that the SLNB without completion ALND can safely replace ALND as the procedure of choice for axillary staging in breast cancer patients with a clinically negative axilla. 


\section{References}

I. Carter CL, Allen C, Henson DE. Relation of tumor size, lymph node status, and survival in 24,740 breast cancer cases. Cancer 1989;63:181-7.

2. Purushotham AD, Upponi S, Klevesath MB, Bobrow L, Millar K, Myles JP, Duffy SW. Morbidity after sentinel lymph node biopsy in primary breast cancer: results from a randomized controlled trial. J Clin Oncol. 2005;23:4312-21.

3. Schulze T, Mucke J, Markwardt J, Schlag PM, Bembenek A. Long-term morbidity of patients with early breast cancer after sentinel lymph node biopsy compared to axillary lymph node dissection. J Surg Oncol 2006;93:109-19.

4. Mansel RE, Fallowfield L, Kissin M, et al. Randomized multicenter trial of sentinel node biopsy versus standard axillary treatment in operable breast cancer: the ALMANAC Trial. J Natl Cancer Inst 2006:98:599-609.

5. International Union Against Cancer (UICC). TNM classification of malignant tumours. 6th ed. New York: Wiley-Liss; 2002.

6. Roumen RM, Valkenburg JG, Geuskens LM. Lymphoscintigraphy and feasibility of sentinel node biopsy in 83 patients with primary breast cancer. Eur J Surg Oncol 1997;23:495-502.

7. Roumen RM, Kuijt GP, Liem IH, van Beek MW. Treatment of 100 patients with sentinel node-negative breast cancer without further axillary dissection. Br J Surg. 2001;88:1639-43.

8. Smidt ML, Janssen CM, Kuster DM, Bruggink ED, Strobbe LJ. Axillary recurrence after a negative sentinel node biopsy for breast cancer: incidence and clinical significance. Ann Surg Oncol 2005;12:29-33.

9. de Kanter AY, Menke-Pluymers MM, Wouters MW, Burgmans I, van Geel AN, Eggermont AM. 5-Year follow-up of sentinel node negative breast cancer patients. Eur J Surg Oncol 2006;32:282-6.

10. Naik AM, Fey J, Gemignani M, Heerdt A, et al. The risk of axillary relapse after sentinel lymph node biopsy for breast cancer is comparable with that of axillary lymph node dissection: a follow-up study of 4008 procedures. Ann Surg 2004;240:462-8.

11. Orr RK. The impact of prophylactic axillary node dissection on breast cancer survival--a Bayesian meta-analysis. Ann Surg Oncol 1999;6:109-16.

12. Eindhoven Cancer Registry, Comprehensive Cancer Centre South. http://www.ikcnet.nl/ikz. 27-42006.

13. Mathiesen O, Carl J, Bonderup O, Panduro J. Axillary sampling and the risk of erroneous staging of breast cancer. An analysis of 960 consecutive patients. Acta Oncol 1990;29:721-5.

14. Kiricuta $\mathrm{Cl}$, Tausch J. A mathematical model of axillary lymph node involvement based on 1446 complete axillary dissections in patients with breast carcinoma. Cancer 1992;69:2496-501.

15. Roumen RM, Geuskens LM, Valkenburg JG. In search of the true sentinel node by different injection techniques in breast cancer patients. Eur J Surg Oncol 1999:25:347-51.

16. Bontenbal M, Nortier JW, Beex LV, et al. Adjuvant systemic therapy for patients with resectable breast cancer: guideline from the Dutch National Breast Cancer Platform and the Dutch Society for Medical Oncology. Ned Tijdschr Geneeskd. 2000;144:984-9 [in Dutch].

17. van Diest PJ, van der Wall E, Baak JP. Prognostic value of proliferation in invasive breast cancer: a review. J Clin Pathol 2004;57:675-81.

18. Liberman L. Pathologic analysis of sentinel lymph nodes in breast carcinoma. Cancer 2000;88:971-7.

19. Baak JP, van Diest PJ, Voorhorst FJ, et al. Prospective multicenter validation of the independent prognostic value of the mitotic activity index in lymph node-negative breast cancer patients younger than 55 years. J Clin Oncol 2005;23:5993-6001.

20. Roumen RM, Pijpers HJ, Thunnissen FB, Ruers TJ. Summary of the guideline 'Sentinel node biopsy in breast cancer.' Dutch Work Group 'Sentinel Node Biopsy for Breast Cancer'. Ned Tijdschr Geneeskd 2000;144:1864-7 [in Dutch]. 


\section{Second thoughts on sentinel lymph node biopsy in node-negative breast cancer}

GP Kuijt, RMH Roumen

British Journal of Surgery 2008;95:310-311

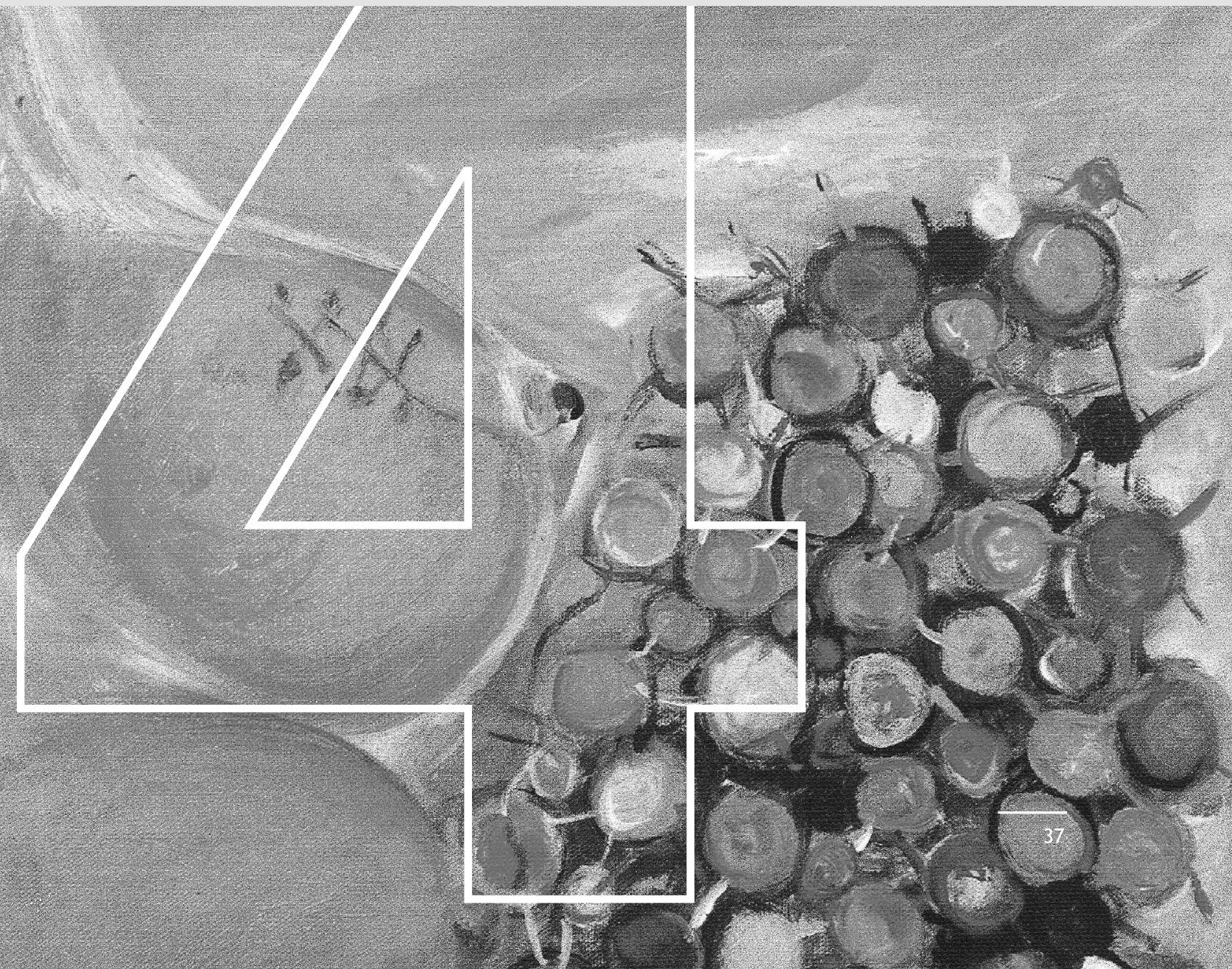




\section{Introduction}

Sentinel lymph node biopsy (SLNB) is an axillary staging procedure that causes less postoperative discomfort than other methods, while allowing a thorough pathological examination of individual lymph nodes. As with any staging procedure, the main concern is the false-negative rate, which for the SLNB can be defined in more than one way ${ }^{1}$. In the present study, a false-negative procedure was defined as a recurrent breast cancer event first occurring in the axillary lymph nodes after a previously negative SLNB. If axillary recurrence is preceded by relapse of cancer in the same breast, whether a second primary or true recurrence, it is difficult to determine whether the axillary recurrence is a new event after the breast cancer recurrence or a primary false-negative event. Therefore, in this paper, axillary relapse after recurrent cancer in the breast is not considered to be a false-negative event. Only patients with isolated axillary recurrence as a presenting symptom were included.

Many studies including patients who were SLNB negative, most with short follow-up, have published similar findings ${ }^{3}$ : low axillary recurrence rates of less than $1 \%$. It was expected that, if recurrence does take place, it is most likely to occur within the first few years of diagnosis. This report presents long-term follow-up of a cohort of 100 SLNB-negative patients first described in $2001^{3}$.

\section{Methods}

From September 1997 to June 2000, 143 patients with breast cancer, of whom 100 were SLNB negative, were studied prospectively ${ }^{3}$. Patients were offered SLNB if their tumour was clinically smaller than $3 \mathrm{~cm}$ in diameter and if no lymph nodes were palpable in the axilla. Informed consent was obtained from all patients. All but one of the patients were female, median age at diagnosis 59 (range 33-86) years. Demographic data have been published previously ${ }^{3}$.

The SLNB technique included peritumoural injection of technetium-labelled human albumin (Nanocoll $\circledast$; Sorin Biomedica Diagnostics, Vercelli, Italy) as well as periareolar injection of $2.5 \%$ Patent Blue dye (Laboratoire Guerbet, Aulnay-sous-Bois, France) ${ }^{2}$. SLNB included palpation of the axilla after harvesting the sentinel nodes. If additional enlarged non-radioactive or dyed lymph nodes were found, then these were also removed and analysed. The mean and median number of sentinel lymph nodes per patient was two (range 1-4). The sentinel nodes were serially sectioned and stained with haematoxylin and eosin, as well as immunostained with Pan Ab-3 anticytokeratin (Neomarkers, Fremont, California, USA). The original pathology was reviewed for the present report, and the specimens from patients with recurrent axillary disease were further sectioned and stained. 
Outpatient follow-up was at 3-monthly intervals for the first year, then twice a year. After 5 years, outpatient visits were reduced to once a year. Follow-up included a physical examination and regular mammography. Further investigation including computed tomography and bone scintigraphy were performed as indicated when locoregional recurrence or distant metastasis was suspected.

\section{Results}

Only one from the original 100 patients with a negative SLNB was lost to follow-up (emigration). Median follow-up of the remaining 99 patients was 6.5 (range 0.3-8.6) years, calculated from the time of the last outpatient visit or death (data gathered from correspondence or by contacting the patient's general practitioner). During this interval, 13 patients died: five from breast cancer, one from a non-related gastric cancer and seven from non-cancer-related causes.

Of the 99 patients for whom follow-up was available, 18 had a recurrent breast cancer event; five of these had ipsilateral axillary recurrence between 14 and 90 months after initial surgery without further tumour in the breast. Even after repeat sectioning, immunostaining and review, there was no sign of metastasis in these nodes. Table 4.1 shows the clinicopathological characteristics at diagnosis. Another five of the 18 patients had recurrent cancer in the ipsilateral breast: two invasive breast cancer, one mastitis carcinomatosa, one scar recurrence and one ductal carcinoma in situ (DCIS). Four of the 18 patients had a second breast cancer in the contralateral breast: three invasive cancer and one DCIS. Finally, the remaining four of these 18 patients presented with a distant metastasis as their first recurrence: two lung, one brain and one bone metastasis.

Table 4.1 Primary clinicopathological features in the five patients with axillary recurrence without ipsilateral local relapse.

\begin{tabular}{|c|c|c|c|c|c|c|c|c|}
\hline Patient & $\begin{array}{c}\text { DFS } \\
\text { (months) }\end{array}$ & $\begin{array}{c}\text { Age } \\
\text { (years)* }\end{array}$ & Menopausal status* & Surgery† & $\begin{array}{l}\text { Tumour } \\
\text { size } \\
(\mathrm{mm})^{\dagger}\end{array}$ & $\begin{array}{l}\text { Tumour } \\
\text { grade }\end{array}$ & $\begin{array}{l}\text { Tumour } \\
\text { histology }\end{array}$ & $\begin{array}{l}\mathrm{ER} / \mathrm{PR} \\
\text { status }\end{array}$ \\
\hline$A$ & 14 & 46 & Premenopausal & $\mathrm{BCT}$ & 8 & 2 & Ductal & $+/+$ \\
\hline B & 20 & 84 & Postmenopausal & BCT & 17 & 3 & Ductal & $-/-$ \\
\hline C & 33 & 47 & Premenopausal & $\mathrm{BCT}$ & 14 & 1 & Ductal & $+/+$ \\
\hline$D$ & 79 & 60 & Postmenopausal & BCT & 9 & 1 & Tubular & $+/+$ \\
\hline $\mathrm{E}$ & 90 & 40 & Premenopausal & Mastectomy & 20 & 1 & Ductal & $+/-$ \\
\hline
\end{tabular}

None of the five women had received adjuvant hormone therapy or chemotherapy. *At diagnosis; tprimary tumour characteristics; DFS, disease-free survival; $B C T$, breast-conserving treatment; ER/PR, oestrogen receptor/progesterone receptor. 


\section{Discussion}

Data from the present series showed that, after a median follow-up of 6.5 years, the axillary recurrence rate after negative SNLB was substantially higher than previously reported, and that recurrence is a continuum, not necessarily occurring within the first few years of diagnosis.

In the study published in $2001^{3}$, only one patient had axillary lymphatic recurrence after 14 months. It was concluded that the false-negative rate after previous negative SLNB was lower than expected, as it was thought more than two-thirds would occur within 2 years of diagnosis ${ }^{4}$. Most studies of negative SLNB without further ALND have relatively short follow-up, usually less than 2 years.

A practical definition of a false-negative SLNB, also from a patient's point of view, is axillary recurrence during follow-up after a previous SLNB procedure, including lymphatic mapping, surgical biopsy and pathological analysis. In the 99 patients in this study for whom follow-up was available, this occurred five times in contrast to the single case reported earlier. Three of these patients were premenopausal, possibly indicating a more aggressive cancer biology. Other possible explanations for falsenegative SLNB, such as discrepancies between lymphoscintigraphy and surgical results, were not found here. In the 2001 report it was calculated that, with a 95\% sensitivity of the SLNB procedure and assuming a $40 \%$ a priori chance of finding a positive sentinel node, $3 \%$ of node-negative women could be expected to develop an isolated axillary recurrence. The present data show that this number is likely to be higher, being up to $10 \%$.

It is likely that this observation indicates the ongoing systemic manifestation of breast cancer, with a large variation in the timing of recurrences. While two were detected within 2 years of the initial diagnosis, the other three were found as long as 7 years later.

SNLB remains the most efficient and patient-friendly axillary staging procedure in breast cancer, but it has a more than negligible false-negative rate, and women should be informed of this. Also, it is a misconception to think that most recurrences will occur within the first few years of diagnosis; axillary relapse can still happen many years after initial surgery. Therefore, long-term follow-up of women with negative SLNB should also include specific attention to the axilla. 


\section{References}

1. Estourgie SH, Nieweg OE, Rutgers EJ, Kroon BB. What is a false-negative result for sentinel node procedures in breast cancer? J Surg Oncol 2003;82:141-142.

2. Roumen RM, Valkenburg JG, Geuskens LM. Lymphoscintigraphy and feasibility of sentinel node biopsy in 83 patients with primary breast cancer. Eur J Surg Oncol 1997;23:495-502.

3. Roumen RM, Kuijt GP, Liem IH, van Beek MW. Treatment of 100 patients with sentinel node-negative breast cancer without further axillary dissection. Br J Surg 2001;88:1639-1643.

4. Fisher B, Redmond C, Fisher ER, Bauer M, Wolmark N, Wickerham DL et al. Ten-year results of a randomized clinical trial comparing radical mastectomy and total mastectomy with or without radiation. N Engl J Med 1985;312:674-681. 


\section{The prognostic significance of axillary lymph-node micrometastases in breast cancer patients}

GP Kuijt, AC Voogd, LV van de Poll-Franse, LJEE Scheijmans, MWPM van Beek, RMH Roumen European Journal of Surgical Oncology 2005;31:500-505

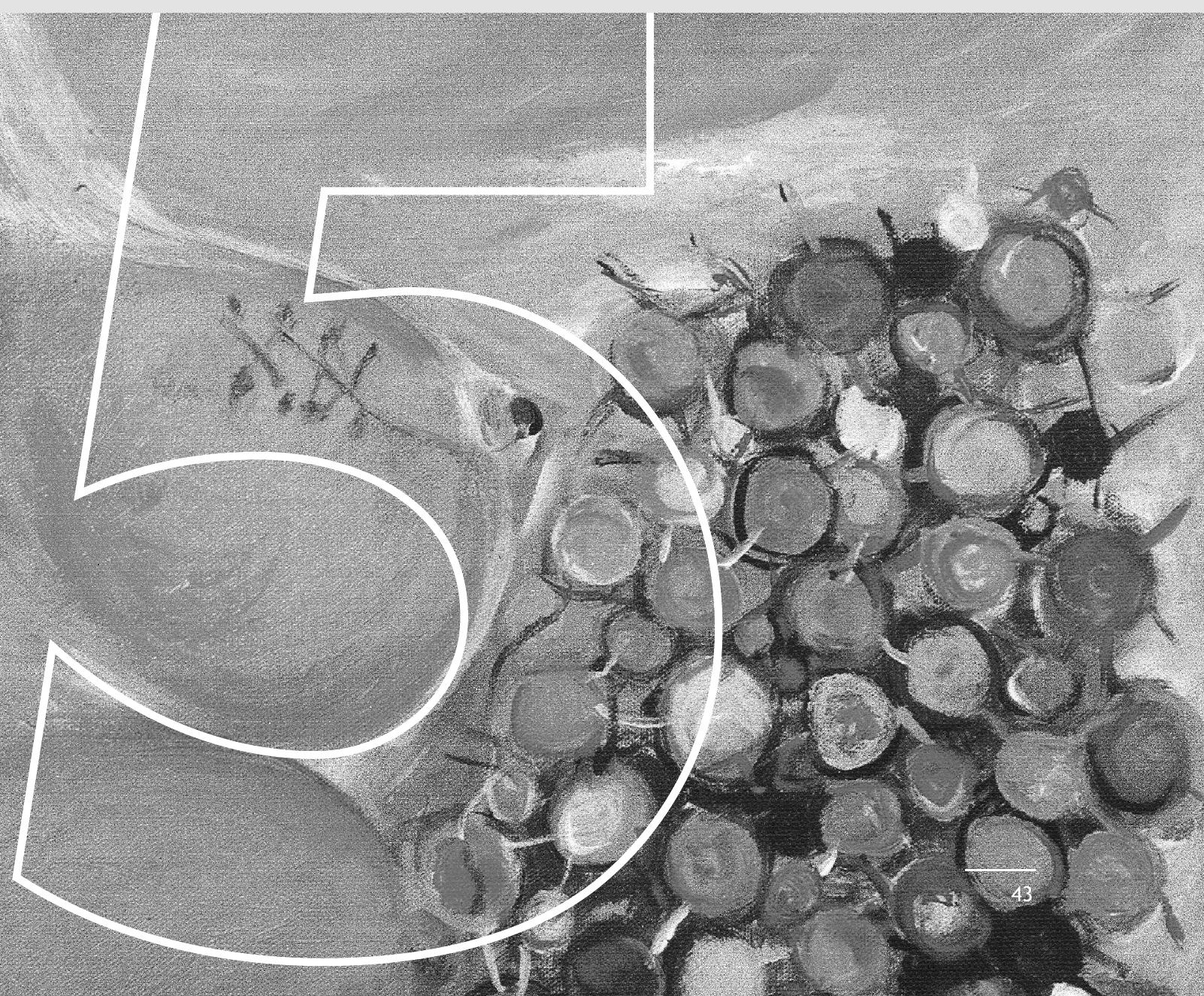




\section{Abstract}

Aims

We analysed the results of regional community practice to determine the prognosis of axillary lymph-node micrometastases in women with breast cancer.

\section{Methods}

Patient data were retrieved from the population-based Eindhoven Cancer Registry in The Netherlands. Between 1975 and 1997, 10,111 patients were diagnosed as having invasive breast cancer. We compared three subgroups: patients without axillary involvement (the pNO group), patients with axillary micrometastasis ( $\leq 2 \mathrm{~mm}$, the pN1a group), and patients with a macrometastasis in only one lymph node (>2 $\mathrm{mm}$, the pN1 group). Follow-up was completed until April 2002.

Results

The relative risk (RR) of dying comparing the pN1a group and the $\mathrm{pN} 1$ group to the pN0 group was 1.32 and 1.34, respectively. Excluding the adjuvantly treated patients, the RR of dying was 1.51 and 1.91, respectively for the pN1a group and the pN1 group vs. the pNO group.

\section{Conclusion}

This outcome data of nearly 25 years of community practice show that breast cancer patients with axillary lymph node micrometastasis have a significantly worse survival rate than those without independent of age or tumour size. Adjuvant systemic therapy should be contemplated when treating these patients. 


\section{Introduction}

The detection of metastases in axillary lymph nodes of patients with breast cancer is highly dependent on the methods used to find them. Historically, a lymph node examination is based on haematoxylin and eosin (H\&E) staining of one or two sections through the largest diameter of the lymph node. Micrometastases were defined by the American Joint Committee on Cancer as metastatic lesions no larger than $2.0 \mathrm{~mm}$ in greatest dimension. In the fifth edition of AJCC cancer staging manual these lesions were classified as pN1a. However, a footnote was added stating that the prognosis of patients with $\mathrm{pN} 1 \mathrm{a}$ is similar to that of patients with $\mathrm{pNO}^{1}$. Earlier editions had classified patients with micrometastatic disease as pNO.

In the ongoing debate concerning the prognostic significance of micrometastatic axillary breast disease, we present the results of nearly 25 years of regional community practice. In a population of 10,111 breast cancer patients, we found 179 patients with H\&E micrometastasis and compared them to 4377 patients without axillary involvement and to 640 patients with only one positive lymph node.

\section{Patients and methods}

\section{Data collection}

Patient data were retrieved from the population based Eindhoven Cancer Registry, which serves a population of nearly one million inhabitants in the south-eastern Netherlands ( $6 \%$ of the Dutch population). Data were collected by the cancer registry from copies of the pathology reports made by 10 pathologists in three different laboratories and the medical records of eight community hospitals and one department of radiotherapy.

In the period 1975-1997, there were 10,111 patients diagnosed as having invasive breast cancer. Regional treatment guidelines, implemented in 1978, recommended complete axillary dissection for all patients with resectable breast cancer. Axillary lymph nodes were evaluated histologically with haematoxylin and eosin (H\&E) staining, usually of a single section. All patients were staged according to the TNM classification system of the UICC. Excluded were 1193 patients with incomplete documentation regarding the pathological tumour stage and 1869 patients with direct tumour extension to the chest wall or skin, inflammatory cancer (T4 classification), or clinical signs of distant metastases (M1 classification). This left 7049 breast cancer patients pathologically staged as stage I ( $\left.\mathrm{T}_{1} \mathrm{~N}_{0} \mathrm{M}_{0}\right)$, stage IIA ( $\left.\mathrm{T}_{1} \mathrm{~N}_{1} \mathrm{M}_{0} ; \mathrm{T}_{2} \mathrm{No}_{0} \mathrm{Mo}\right)$, stage IIB ( $\left.\mathrm{T}_{3} \mathrm{NoM}_{0}, \mathrm{~T}_{2} \mathrm{~N}_{1} \mathrm{Mo}\right)$ or stage IIIA ( $\left.\mathrm{T}_{3} \mathrm{~N}_{1} \mathrm{Mo}_{0} \mathrm{~T}_{1-3} \mathrm{~N}_{2} \mathrm{Mo}\right)$. In this group of patients, 4377 had no axillary lymph-node metastases (classified as pNO) and 133 had only 
micrometastatic disease, none larger than $2 \mathrm{~mm}$ (classified as pN1a). To increase the statistical power, the group of 133 patients with micrometastases was enlarged by adding 46 patients from a comparable adjacent region with the same treatment guidelines. The exact number of positive axillary lymph nodes has been recorded since 1984, and in the period between January 1, 1984, and December 31, 1997, there were 640 patients with only a single positive lymph node with a metastasis larger than $2 \mathrm{~mm}$. The remaining 1899 patients had more than one positive macrometastatic lymph node and were left out of this study. Thus, three groups of patients were available for analysis: 4377 patients without axillary metastases, 179 patients with micrometastases smaller than $2 \mathrm{~mm}$, and 640 patients with only a single positive lymph node containing a macrometastasis larger than $2 \mathrm{~mm}$.

Follow-up was completed until April 2002. This information was obtained from the municipal registries in the area of the Eindhoven Cancer Registry and the Central Bureau for Genealogy. The latter is an institution that collects data on all deceased Dutch citizens via the municipal registries. In this way, information on patients who had moved outside the registry area was also obtained. Patients who died outside the Netherlands were wrongly considered as 'being alive'. However, the estimated proportion of these patients was less then $0.3 \%$.

\section{Statistical analysis}

Survival analysis was carried out using the life-table method to evaluate the prognosis after diagnosis of breast cancer. Survival time was defined as the period between the date of diagnosis and the data of death or last follow-up. Patients with incomplete follow-up were censored at the date of last follow-up. Patient without axillary metastases ( $p N 0)$, with micrometastases ( $\mathrm{pN} 1 \mathrm{a})$, or macro metastasis in one lymph node ( $\mathrm{pN} 1$ ) were compared by means of the log-rank test. Multivariate analyses were carried out using Cox proportional hazards regression models to adjust for the potential confounding effects of age and tumour size. To exclude any possible confounding effect of adjuvant systemic treatment, the univariate and multivariate analysis were also performed after excluding all patients receiving chemotherapy and/or hormonal therapy. Hazard ratios with 95\% confidence intervals (RR) and $P$ values were estimated with respect to the reference category for each covariate.

\section{Results}

\section{General population characteristics according to axillary nodal status}

The mean age at the time of diagnosis of the patients with micrometastatic breast cancer was slightly lower than those with node-negative disease, although this was not statistically significant (Table 5.1). There was also no significant difference in age 
observed between the patients with micrometastases and those with a macro metastasis in one lymph node. Patients with micrometastatic disease had larger tumours than the node-negative patients $(p=0.001)$. No differences in tumour size were observed between patients with micrometastatic disease and those with one lymph node with macro metastases $(p=0.67)$. The histological type was comparable in all three groups. Of the patients with micrometastases, $51 \%$ received adjuvant systemic treatment, vs. $2 \%$ of those with negative lymph nodes and $76 \%$ of the patients with one positive lymph node. Information on tumour grade was missing for $72 \%$ of the patients. However, when patients with a known tumour grade were analysed, the proportion of well-differentiated and poorly differentiated tumours did not differ between the three patient groups.

Table 5.1 General demographic characteristics at the time of diagnosis of the primary tumour according to pathological nodal status $(n=5196)$.

\begin{tabular}{|c|c|c|c|c|}
\hline & \multicolumn{3}{|c|}{ Pathological nodal status (pN) } & \multirow[t]{2}{*}{ P-value } \\
\hline & pNO (n=4377) & pN1a (n=179) & $\mathrm{pN} 1(\mathrm{n}=640)$ & \\
\hline \multicolumn{5}{|l|}{ Age group } \\
\hline$<50$ & 1312 & 75 & 215 & 0.0005 \\
\hline $50-69$ & 2143 & 81 & 316 & \\
\hline$\geq 70$ & 922 & 23 & 109 & \\
\hline \multicolumn{5}{|l|}{ Tumour grade $^{a}$} \\
\hline Good & 120 & 8 & 18 & 0.052 \\
\hline Moderate & 647 & 16 & 124 & \\
\hline Poor & 419 & 14 & 99 & \\
\hline \multicolumn{5}{|l|}{ Pathological tumour size, pT } \\
\hline pT1 & 2724 & 86 & 299 & $<0.0001$ \\
\hline рT2 & 1557 & 84 & 317 & \\
\hline pT3 & 96 & 9 & 24 & \\
\hline \multicolumn{5}{|l|}{ Histological type ${ }^{b}$} \\
\hline Ductal & 3493 & 144 & 509 & 0.0008 \\
\hline Lobular or mixed & 528 & 22 & 102 & \\
\hline Mucinous & 107 & 1 & 3 & \\
\hline Tubular & 135 & 4 & 15 & \\
\hline Medullar & 45 & 6 & 6 & \\
\hline \multicolumn{5}{|l|}{ Adjuvant systemic treatment } \\
\hline $\mathrm{CT}$ & 52 & 45 & 189 & $<0.0001$ \\
\hline $\mathrm{HT}$ & 60 & 45 & 294 & \\
\hline СТCHT & 2 & 2 & 2 & \\
\hline None & 4263 & 87 & 155 & \\
\hline Radiotherapy (number treated) & 2684 & 125 & 419 & 0.013 \\
\hline
\end{tabular}

pN1, metastasis > 2 mm in one lymph node; CT, chemotherapy; $H T$, hormonal therapy; ${ }^{a} 3731$ missing values for tumour grade; ${ }^{\mathrm{b}} 76$ missing values for histological grade. 


\section{Prognosis according to axillary nodal status}

The overall (unadjusted) survival of the patients with micrometastatic disease was worse compared to patients with node-negative breast cancer, but did not reach statistical significance $(p=0.13)$. The 10 -year overall survival rates were $69.0 \%$ for the pN0 group, $61.9 \%$ for the pN1a group, and 59.5\% for the pN1 group (Figure 5.1).

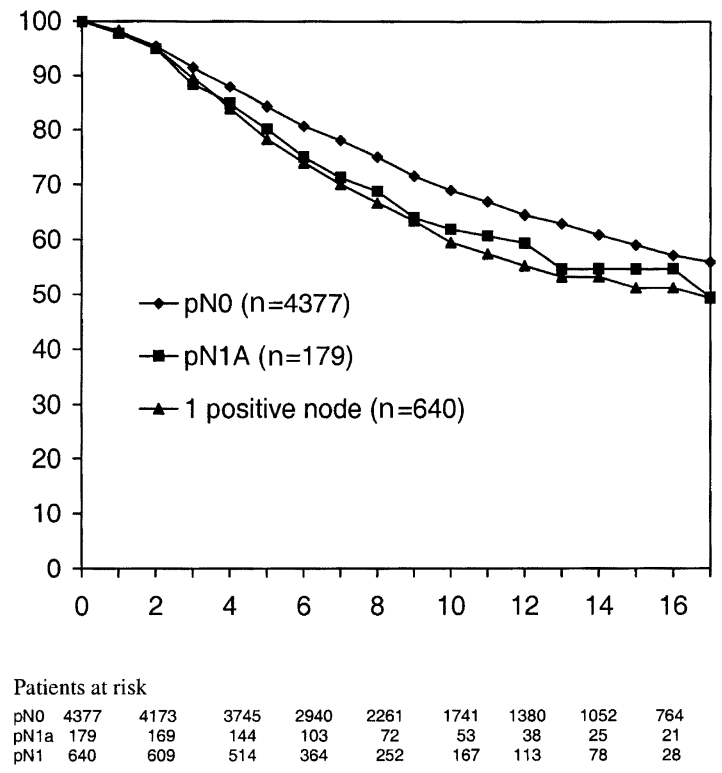

Figure 5.1 Overall survival according to pathological nodal status.

After restriction of the analysis to the patients without adjuvant systemic treatment, the overall survival was significantly worse for patients with micrometastases than for patients with node-negative breast cancer $(p=0.019)$, while no significant difference was observed between the patients with micrometastases and those with a macrometastasis in one lymph node $(p=0.13)$. The 10-year survival rates were 69.7, 56.1 and $44.3 \%$, respectively (Figure 5.2 ).

In the multivariate analysis controlling for patient age and tumour size, micrometastatic disease was a significant predictor of mortality (hazard ratio 1.32; 95\% Cl 1.03-1.69) (Table 5.2). In a multivariate analysis of the patients without adjuvant systemic treatment, those with micrometastatic disease had a significantly higher risk of dying as compared to patients with node-negative breast cancer (hazard ratio 1.51; 95\% Cl 1.11-2.06). 


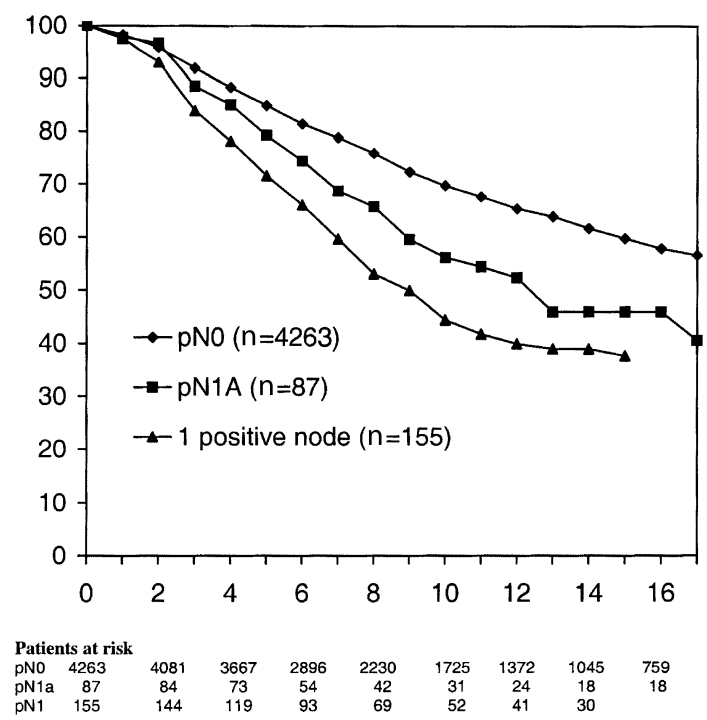

Figure 5.2 Overall survival according to pathological nodal status, patients without adjuvant systemic treatment.

Table 5.2 Results of the multivariate analysis for overall mortality for all patients and for patients without adjuvant systemic treatment.

\begin{tabular}{|c|c|c|c|c|c|c|}
\hline \multirow[t]{2}{*}{ Characteristics } & \multicolumn{3}{|c|}{ All patients $(n=5196)$} & \multicolumn{3}{|c|}{ Patients without systemic treatment $(n=4505)$} \\
\hline & $\mathrm{HR}$ & $95 \% \mathrm{Cl}$ & $P$ value & $H R$ & $95 \% \mathrm{Cl}$ & $P$ value \\
\hline $\begin{array}{l}\text { Age (per year } \\
\text { increase) } \\
\text { PT }\end{array}$ & 1.04 & $(1.04-1.05)$ & $<0.0001$ & 1.04 & $(1.04-1.05)$ & $<0.0001$ \\
\hline $\begin{array}{l}\text { pT2+pT3 vs. pT1 } \\
\text { pN }\end{array}$ & 1.41 & $(1.29-1.55)$ & $<0.0001$ & 1.37 & $(1.24-1.52)$ & $<0.0001$ \\
\hline pN1a vs. pNO & 1.32 & $(1.03-1.69)$ & 0.029 & 1.51 & $(1.11-2.06)$ & 0.009 \\
\hline pN1 vs. pN0 & 1.34 & (1.17-1.54) & $<0.0001$ & 1.91 & (1.54-2.37) & $<0.0001$ \\
\hline pN1 vs. pN1a & 1.02 & (0.77-1.34) & 0.909 & 1.27 & $(0.87-1.83)$ & 0.212 \\
\hline
\end{tabular}

$\mathrm{HR}$, hazard ratio; $95 \% \mathrm{Cl}, 95 \%$ confidence interval; $\mathrm{pN} 1$, metastasis $>2 \mathrm{~mm}$ in one lymph node.

\section{Discussion}

This large, population-based study with long term follow-up shows that breast cancer patients with micrometastases detected by H\&E staining alone without serial sectioning have a prognosis which is worse than that of node-negative patients and better than that of patients with macrometastatic disease in only one lymph node. 
Overlooking the literature, the significance of finding axillary micrometastasis in breast cancer patients remains a controversial topic. Most early studies showed no prognostic disadvantage, lending support to the viewpoint held until recently by the AJCC that $\mathrm{pN} 1 \mathrm{a}$ should be treated as $\mathrm{pNO}^{1}$. These studies were, however, mostly small with less than 100 patients, and with a follow-up of less than 5 years ${ }^{2}$.

The detection of metastases is directly dependent on the methods used to look for them. Conventionally, a lymph node examination is based on H\&E staining of one or two sections through the largest dimension of the lymph node. Because a significant percentage of axillary node negative cancer patients go on to develop further disease, Dutch treatment guidelines recommend using serial sectioning and immunohistochemistry $(\mathrm{IHC})$ for lymph nodes that are negative at H\&E staining. IHC detects smaller micrometastases or even isolated tumour cells. The introduction of the sentinel lymph node biopsy (SLND) has made it feasible to use serial sectioning and $\mathrm{IHC}$ in routine daily practice. This allows the pathologist to focus and more thoroughly evaluate the most relevant lymph node(s). In 1997, a review was published on the prognostic impact of micrometastases, in which it was concluded that patients with micrometastases detected by serial sectioning and IHC in H\&E negative nodes of complete ALND specimens have a definite survival disadvantage ${ }^{3}$. Occult metastases, defined as metastases missed at the original pathological analysis, were detected in 9-33\% of originally node-negative cases, depending on the serial section interval. More recently Tjan-Heijnen et al. reviewed the results of eight studies with a followup of at least 5 years and including more than 100 patients where a micrometastasis was defined as smaller than $2 \mathrm{~mm}$. According to their interpretation of the available data, there is no proof of the prognostic relevance of isolated tumour cells and (small) micrometastases ${ }^{4}$.

Modern techniques have developed that allow identification of up to a single malignant cell, but leave unanswered the question of where clinical relevance stops. In order to answer this, a large body of outcome data must be collected where a distinction is made between micrometastases and isolated tumour cells according to uniform quantitative criteria ${ }^{5}$. To achieve this, the sixth edition of the American Joint Committee on Cancer (AJCC) cancer staging manual has further defined small metastasis. Micrometastases are now defined as being larger than $0.2 \mathrm{~mm}$ but no larger than $2.0 \mathrm{~mm}$ in diameter. Isolated tumour cells, seen as single cells or cell deposits, are no larger than $0.2 \mathrm{~mm}$; their prognosis should be considered to be similar to node negative disease. The AJCC still consider H\&E staining viewed with conventional light microscopy to be the gold standard, and recommend that all metastatic lesions found using IHC be confirmed by H\&E staining. However, to accommodate changing clinical practice, they recommend an additional descriptor (i) to designate immunohistochemical, and (mol) for molecular in those cases where these more sensitive techniques find metastatic disease ${ }^{5}$. The relevance of finding 
such a sub-micrometastatic deposit will most likely be revealed by future analysis of registered outcome data.

Interpretation of the results of our study may be complicated by several factors. All patients were from the pre-sentinel node era and underwent axillary dissection. Serial sectioning of the lymph nodes was not a standard procedure at that time. Thus, some patients with micrometastases or even macrometastases will have remained undetected and have been wrongly classified as node-negative. We think that the proportion of patients with undetected metastatic disease is too small to have had a significant impact on the overall survival of the large node-negative group of patients. Assuming that some misclassification has taken place, the real difference in the overall survival between both patient groups would only have been larger. On the other hand, some patients with micrometastatic disease ( $\mathrm{pN1a}$ ) may have been included in the group with macrometastases (pN1), thus improving the latter's overall survival. The proportion of patients with micrometastatic disease relative to the nodenegative group was $4.1 \%$ in our series, which is lower than the percentage reported in other studies using H\&E staining alone without serial sectioning. For example, Fisher et al. report finding $8 \%$ micrometastasis (although only 21 cases) by analysing available data collected for another prospective study ${ }^{6}$. Possibly they found a higher percentage of cases because their population size was relatively small. Interestingly, though, their life table probability curves of treatment failure rates suggested that the presence of micrometastasis resulted in a disease-free probability that was intermediate between those of patients without and those with macrometastasis. However, this finding was not statistically significant $(p=0.2)$ probably due to small sample size.

Interpretation of our results is further complicated by the lack of information on tumour grade. When comparing the prognosis of patients with negative lymph nodes to that of patients with micrometastases, one would only expect a confounding effect of tumour grade if the two groups differed in this respect. However, among the patients for whom information on tumour grade was available, no such difference was observed. This makes it highly unlikely that accounting for tumour grade in the multivariate analysis would change the results.

Numbers in our study are too small to draw conclusions about the effect of adjuvant systemic treatment in patients with micrometastatic disease in the lymph nodes. However, it is interesting to note that $51 \%$ of the patients in the pN1a group actually did receive adjuvant systemic therapy in a time when this was not the standard of care. Maybe this was based on other prognostic factors influencing clinical judgement such as tumour size or grade. Important in this context is that the meta analyses of the Early Breast Cancer Trialists' Collaborative Group have shown that the relative benefit from adjuvant systemic treatment is independent of axillary lymph node 
status ${ }^{7}$. However, the absolute benefit will be larger for patients with a poor prognosis than for patients with a good prognosis. Of course, decision making regarding systemic treatment is also guided by the primary tumour characteristics.

The advent of the sentinel node procedure will increase the proportion of patients with small, previously undetected metastatic disease. Their prognosis will be better than that of the patients with micrometastases in this series, assuming that there is a linear correlation between size of nodal metastases and survival. And although the difference with node-negative patients may still be clinically significant, much larger series are needed to confirm this. Until the results of these ongoing studies are clear, we must rely on the available evidence. This teaches us to be liberal in treating women with micrometastatic breast cancer adjuvantly because, as this study shows, in the past we have underestimated the importance of axillary micrometastasis. 


\section{REFERENCES}

1. Flemming ID, Cooper JS, Henson DE, et al. In: A.J.C.C. Cancer staging manual. 5th ed. Philadelphia: Lippincott-Raven; 1997:174.

2. Gray RJ, Cox CE, Reintgen DS. Importance of missed axillary micrometastases in breast cancer patients. Breast J 2001;7:303-7.

3. Dowlatshahi K, Fan M, Snider HC, Habib FA. Lymph node micrometastases from breast carcinoma. Reviewing the dilemma. Cancer 1997;80:1188-97.

4. Tjan-Heijen VCG, Bult P, de Widt-Levert LM, Ruers TJ, Beex LVAM. Micro-metastases in axillary lymph nodes: an increasing classification and treatment dilemma in breast cancer due to the introduction of the sentinel lymph node procedure. Breast Cancer Res Treat 2001;70:81-8.

5. Singletary SE, Allred C, Ashley $\mathrm{P}$, et al. Revision of the American Joint Committee on cancer staging system for breast cancer. J Clin Oncol 2002;20:3628-36.

6. Fisher ER, Palekar A, Rochette H, Redmond C, Fisher B. Pathologic findings from the National Surgical Adjuvant Breast Project (Protocol No. 4). V. Significance of axillary nodal micro- and macrometastases. Cancer 1978;42:2032-8.

7. Early Breast Cancer Trialists' Collaborative Group. Polychemotherapy for early breast cancer: an overview of the randomized trials. Lancet 1998;352:930-42. 



\section{The significance of one positive axillary node}

GP Kuijt, LV van de Poll-Franse, RMH Roumen, MWPM van Beek, AC Voogd European Journal of Surgery Oncology 2006;32:139-142

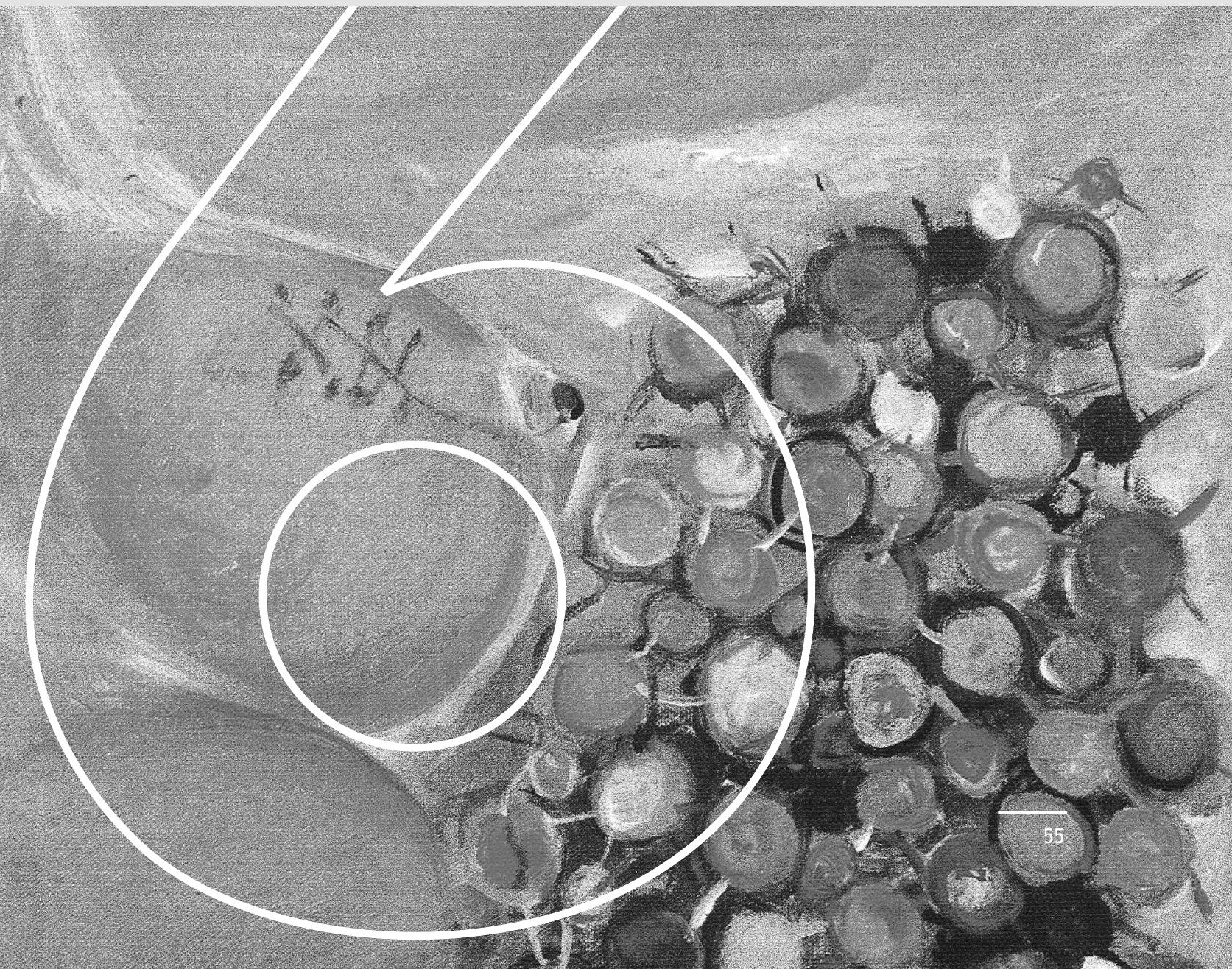




\section{Abstract}

Aims

The aim of this study was to identify a subgroup of patients with breast cancer that can safely avoid axillary dissection.

\section{Methods}

Using data collected by the Eindhoven Cancer Registry, we compared the clinicopathological features of 489 patients with only one positive lymph node to those of 817 patients with more than one positive lymph node in the axilla. All patients underwent complete axillary dissection, not preceded by a sentinel node biopsy.

Results

Tumour size greater than $1 \mathrm{~cm}$, harvesting more than 15 axillary lymph nodes at histopathological examination, metastasis size larger than $2 \mathrm{~mm}$, extranodal extension, and nodal involvement of the axillary apex are independently associated with the occurrence of more than one metastatic axillary lymph node.

\section{Conclusion}

No subgroup could be identified in which axillary dissection can always be omitted. However, tumour size $<1 \mathrm{~cm}$, finding a micrometastasis rather than a macrometastasis, and especially not finding extranodal extension were independently associated with finding only one positive axillary lymph node. 


\section{Introduction}

Depending on the technique used at histopathological examination and the size of the metastasis, $21-100 \%$ of breast cancer patients undergoing a completion axillary dissection after a sentinel lymph node biopsy have no additional lymph node metastasis other than that initially found in the sentinel node ${ }^{1,2}$. In retrospect, these patients might have been spared further axillary dissection and its associated morbidity. Thus, it is important to try to define prognostic factors that can identify those breast cancer patients whose only axillary metastasis is the one found in the sentinel node.

In population based data collected by the Eindhoven Cancer Registry there is a group of breast cancer patients with only one positive axillary lymph node after axillary lymph node dissection. Assuming perfect performance of the sentinel lymph node biopsy as a diagnostic test to detect a positive lymph node, this one positive lymph node would be the sentinel node. This group of patients is analogous to the group of patients whose sentinel node is the only positive node after a completion axillary dissection. In the present study, we compare the clinico-pathological features of patients with only one positive lymph node to those of patients with more than one positive lymph node in order to identify prognostic factors associated with further axillary metastatic involvement. The aim is to define a subgroup of patients who can safely avoid a completion axillary dissection after finding a positive sentinel node.

\section{Patients and methods}

\section{Patient selection}

Patient data were retrieved from the population-based Eindhoven Cancer Registry, which currently serves a population of more than two million inhabitants in the Southeastern Netherlands ( $14 \%$ of the Dutch population). Data were collected by the cancer registry from copies of the pathology reports made by 10 pathologists in three different laboratories and the medical records of eight community hospitals and one department of radiotherapy. These laboratories and treatment facilities all adhere to the same treatment guidelines.

In the period 1984-2000, there were 9627 patients diagnosed as having invasive breast cancer. Of these patients, 3143 (33\%) had one or more lymph nodes containing metastasis found during pathological workup using a haematoxylin and eosin stain of one or two sections of the nodes. We excluded 476 patients where the pathologist reported less than six lymph nodes in the surgical axillary specimen because we consider this an indicator of an incomplete axillary dissection. Lymph node status was 
missing for an additional nine patients who were, therefore, also excluded. Our current sentinel node protocol calls for the exclusion of patients with palpable or pathologic axillary lymph nodes, as well as those with a primary tumour larger than $5 \mathrm{~cm}$. To make our study model comparable to the current sentinel node situation, we excluded 946 patients with palpable axillary lymph nodes, and 282 patients with tumours larger than $5 \mathrm{~cm}$. We also excluded 124 patients who had undergone a sentinel node procedure to avoid confounding due to differences in pathological workup. This left 1306 patients with a complete axillary dissection to be studied, of which 489 patients had only one positive lymph node analogous to the group in which the sentinel node is the sole metastatic lymph node. This group was compared to 817 patients with more than one positive lymph node which is analogous to the group for which further axillary dissection would also have been indicated if a sentinel node procedure had been performed. Of these 817 patients, 440 had two or three positive nodes and 377 had four or more positive nodes.

\section{Statistical analysis}

Data were analysed in SAS (version 8.02 SAS Institute Inc., Cary, North Carolina, USA). P-values less than 0.05 were considered statistically significant. The chi-square test was used to detect differences in patient and tumour characteristics between the patients with one and those with more than one positive lymph node. To study the predictive value of the different parameters, uni- and multivariate logistic regression analyses were performed including the following covariates: patient age, period of diagnosis, tumour site, histological type, tumour size, tumour grade, lymphovascular invasion, oestrogen receptor status, progesterone receptor status, number of lymph nodes examined, number of positive lymph nodes, size of metastasis ( $\leq$ or $>$ than $2 \mathrm{~mm}$ ), extranodal extension, and axillary apex involvement. Variables that proved statistically significant in the univariate analysis were included in the multivariate analysis. Age was also included in the multivariate analysis as a covariate.

\section{Results}

When comparing breast cancer patients with one and more than one positive lymph node in their axillary clearance specimen, the following significant differences were found: patients with one positive lymph node had smaller tumours, had a smaller number of lymph nodes examined, were more likely to have micrometastasic disease $(\leq 2 \mathrm{~mm}$ ) and less likely to have extranodal extension or metastatic disease in the axillary apex. No significant differences were found with respect to age, period of diagnosis, location of the primary tumour, or its histological type. The interpretation of the outcome concerning tumour grade, lymphovascular invasion, and oestrogen progesterone receptor status was limited due to the number of missing values for 
these variables. However, analysis of the available data did not reach statistical significance.

Univariate and multivariate analyses (Table 6.1) demonstrated that larger tumours $(\mathrm{OR}>1.9$ when tumour size $>1 \mathrm{~cm}, \mathrm{Cl}$ 1.1-3.2), higher number of lymph nodes examined $(\mathrm{OR}=2$ when $>15$ lymph nodes are found, $\mathrm{Cl}$ 1.3-3.1), extranodal tumour extension ( $\mathrm{OR}=3.3, \mathrm{Cl} 2.5-4.4$ ), and nodal involvement of the axillary apex (OR=9.1, $\mathrm{Cl}$ 5.1-16.3) are independently associated with more than one metastatic lymph node in the axilla. Finding a micrometastasis in a lymph node is associated with a lower axillary load (OR 0.2 for finding $>1$ positive lymph node, $\mathrm{Cl} 0.1-0.5$ ).

Table 6.1 Patient and tumour characteristics according to number of positive lymph nodes $(n=1306)$ and results from uni- and multivariate regression analyses.

\begin{tabular}{|c|c|c|c|c|}
\hline Characteristic & $\begin{array}{l}\text { One positive } \\
\text { lymph node } \\
\quad(n=489)\end{array}$ & $\begin{array}{l}\text { More than one } \\
\text { positive lymph node } \\
\text { ( } n=817)\end{array}$ & $\begin{array}{l}\text { Univariate, OR } \\
\qquad(95 \% \mathrm{Cl})\end{array}$ & $\begin{array}{l}\text { Multivariate }{ }^{a} \\
\text { OR }(95 \% \mathrm{Cl})\end{array}$ \\
\hline \multicolumn{5}{|c|}{ Age group (years) } \\
\hline$<50$ & 156 & 288 & 1,0 & 1.0 \\
\hline $50-69$ & 249 & 371 & $0.8(0.6-1.0)$ & $0.8(0.6-1.0)$ \\
\hline $70+$ & 84 & 158 & $1.0(0.7-1.4)$ & $0.9(0.6-1.3)$ \\
\hline \multicolumn{5}{|c|}{ Tumour size $(\mathrm{cm})^{\mathrm{b}}$} \\
\hline $0.1-1.0$ & 51 & 188 & 1.0 & 1.0 \\
\hline $1.1-2.0$ & 194 & 252 & $2.2(1.4-3.4)$ & $1.9(1.1-3.2)$ \\
\hline $2.1-3.0$ & 170 & 321 & $2.3(1.5-3.7)$ & $1.9(1.1-3.2)$ \\
\hline$>3.0$ & 69 & 56 & $3.1(1.8-5.1)$ & $2.4(1.3-4.2)$ \\
\hline \multicolumn{5}{|c|}{ Number of lymph nodes examined } \\
\hline $6-9$ & 170 & 270 & 1.0 & 1.0 \\
\hline $10-12$ & 183 & 267 & $0.9(0.7-1.2)$ & $1.0(0.7-1.3)$ \\
\hline $13-15$ & 90 & 145 & $1.0(0.7-1.4)$ & $1.0(0.7-1.5)$ \\
\hline$>15$ & 46 & 135 & $1.8(1.3-2.7)$ & $2.0(1.3-3.1)$ \\
\hline \multicolumn{5}{|c|}{ Micrometastasis } \\
\hline No & 439 & 805 & 1.0 & 1.0 \\
\hline Yes & 50 & 12 & $0.1(0.1-0.2)$ & $0.2(0.1-0.5)$ \\
\hline \multicolumn{5}{|c|}{ Extranodal tumour extension $^{c}$} \\
\hline No & 384 & 358 & 1.0 & 1.0 \\
\hline Yes & 103 & 457 & $4.8(3,7-6.2)$ & $3.3(2.5-4.4)$ \\
\hline \multicolumn{5}{|c|}{ Nodal involvement in apex of axilla ${ }^{d}$} \\
\hline No & 466 & 574 & 1.0 & 1.0 \\
\hline Yes & 13 & 230 & $14.4(8.1-25.4)$ & $9.1(5.1-16.3)$ \\
\hline
\end{tabular}

a Including age, size, number of nodes examined, micrometastases, extranodal extension and nodal involvement in the apex of the axilla; ${ }^{b}$ Tumour size was missing for 14 patients; ${ }^{c}$ Information on extranodal tumour extension was missing for four patients; ${ }^{d}$ Information on nodal involvement in apex of axilla was missing for 23 patients. 


\section{Discussion}

Since the introduction of the sentinel lymph node (SN) biopsy, multiple studies have tried to define a group of SN positive patients in whom a completion axillary lymph node dissection can safety be omitted. Degnim et al. ${ }^{2}$. conducted a meta-analysis of 11 studies and concluded that the presence of any one of five characteristics (SN metastasis size $>2 \mathrm{~mm}$, the presence of extranodal extension in the $\mathrm{SN}$, tumour size $>2 \mathrm{~cm}$, more than one positive $\mathrm{SN}$, or lymphovascular invasion in the primary tumour) increased the likelihood of finding a non-SN metastasis by a factor greater than two. More recently, Van Zee et al validated a nomogram predicting the likelihood of additional lymph node metastasis based on nine criteria ${ }^{3}$. The present study approaches this question using population based data from the Eindhoven Cancer Registry.

Finding that primary tumour size greater than $1 \mathrm{~cm}$ nearly doubles the likelihood of finding more than one metastatic lymph node in the axilla is in accordance with past en present literature ${ }^{2-5}$.

Finding that the axilla contains only a micrometastasis $(\leq 2 \mathrm{~mm})$ is, in the present study, strongly associated with finding only one positive lymph node. It is increasingly clear that the clinically relevant cut-off point in metastasis size lies under the traditional $2 \mathrm{~mm}$ mark. Until recently, the prognosis of patients with micrometastasis was considered equivalent to that of patients with no axillary metastasis ${ }^{6}$. In a previous study, we found that in a cohort of 10,111 patients with nearly 25 years of follow-up, the survival of patients with a micrometastasis was intermediate to that of patients with no metastasis and those with a macrometastasis ${ }^{7}$. To accommodate evolving clinical insight, the American Joint Committee on Cancer (AJCC) has further defined small metastasis. Micrometastases are larger than $0.2 \mathrm{~mm}$ but no larger than $2.0 \mathrm{~mm}$ in diameter. Isolated tumour cells, seen as single cells or cell deposits, are less than $0.2 \mathrm{~mm}$; their prognosis is comparable to node negative disease. The AJCC still consider H\&E staining viewed with conventional light microscopy to be the gold standard and recommend that all metastatic lesions found using immunohistochemical techniques be confirmed by H\&E staining. Additionally, a descriptor (i) is recommended to designate immunohistochemical and (mol) for molecular in those cases where these more sensitive techniques find evidence of metastatic disease ${ }^{8}$. The relevance of finding such a submicrometastatic deposit will have to be crystallized by future outcome data.

Finding extranodal extension in a lymph node is strongly and independently associated with finding more than one positive lymph node. Extranodal extension was defined by pathologists as any extracapsular growth of tumour cells. Its clinical importance was first reported by Fisher et al., finding a significant correlation 
between extranodal extension and the involvement of more than three axillary nodes ${ }^{9}$. This was confirmed by other studies, especially in relation to the indication for radiation therapy ${ }^{10-16}$. Stitzenberg et al., analysing the occurrence of non-sentinel node (NSN) involvement given a positive SN, found that $78 \%$ of patients with extranodal extension in the SN had metastasis in NSN while only $29 \%$ of the patients without extranodal had NSN involvement ${ }^{17}$. In the lymph node, metastatic tumour cells first appear in the marginal sinus ${ }^{18}$. Their invasiveness determines their ability to penetrate the medullary sinuses, the medulla, and eventually the cortex, resulting in parenchymal replacement. Extranodal extension is when this process has reached the point of breaking through the capsule into the peri-nodal tissue. In light of this, it seems intuitive that if a metastatic breast cancer is aggressive enough to defeat lymph node defence mechanisms and cause extranodal extension, then it is likely to be aggressive enough to be found in more than one axillary lymph node. Therefore, extranodal extension is a very relevant prognostic factor.

Although apex node involvement was found to be very significant, its relevance in the current sentinel node era is limited because surgical experience is that the $\mathrm{SN}$ is usually located just lateral to the pectoral muscle low in the axilla. A recent study describing lymphatic drainage patterns in breast cancer patients found $11.3 \%$ of breast tumours also drain to the infra-clavicular region (which is where the apex of the axilla lies anatomically), and that $1.9 \%$ drain exclusively infra-clavicularly ${ }^{19}$. This is similar to the data presented here, where the apex of the axilla was the location of the only metastatic lymph node in $2.7 \%$ (13/479) of the patients with only one positive lymph node. In general, the axilla apex only fills with metastases after lower echelon nodes are already metastaticaly involved. This high axillary burden is likely to be discovered in routine pre-operative analysis and so form a contraindication to a SN biopsy. Therefore, although apex involvement is statistically significant, it is only rarely clinically relevant in the $\mathrm{SN}$ situation.

In conclusion, when comparing breast cancer patients with one and more than one metastatic lymph node in an axillary specimen, no subgroup could be identified in which axillary dissection can always be omitted. However, tumour size $<1 \mathrm{~cm}$, finding a micrometastasis rather than a macrometastasis, and especially not finding extranodal extension were independently associated with finding only one positive axillary lymph node. 


\section{References}

1. Cserni G, Gregori D, Merletti F, Sapino A, Mano MP, Ponti A, Sandrucci S, Baltás B, Bussolati G. Metaanalysis of non-sentinel node metastases associated with micrometastatic sentinel nodes in breast cancer. Br J Surg 2004;91:1245-52.

2. Degnim AC, Griffith KA, Sabel MS, Hayes DF, Cimmino VM, Diehl KM, Lucas PC, Snyder ML, Chang AE, Newman LA. Clinicopathologic features of metastasis in nonsentinel lymph nodes of breast carcinoma patients: a meta-analysis. Cancer 2003:98:2307-15.

3. Van Zee KJ, Manasseh DM, Bevilacqua JL, Boolbol SK, Fey JV, Tan LK, Borgen PI, Cody HS 3rd, Kattan MW. A nomogram for predicting the likelihood of additional nodal metastases in breast cancer patients with a positive sentinel node biopsy. Ann Surg Oncol. 2003;10:1140-51.

4. Carter CL. Allen C, Henson DE. Relation of tumor size, lymph node status, and survival in 24,740 breast cancer cases. Cancer 1989;63:181-7.

5. Viale G, Zurrida S, Maiorano E, Mazzarol G, Pruneri G, Paganelli G, Maisonneuve P, Veronesi U. Predicting the status of axillary sentinel lymph nodes in 4351 patients with invasive breast carcinoma treated in a single institution. Cancer 2005;103:492-500.

6. Flemming JD, Cooper JS, Henson DE. A.J.C.C. cancer staging manual. 5th ed. Lippincott-Raven: Philadelphia. 1997:174.

7. Kuijt GP, Voogd AC, van de Poll-Franse LV, Scheijmans UEE, van Beek MWPM, Roumen RMH. The prognostic significance of axillary lymph node micrometastases in breast cancer patients. Eur J Surg Oncol 2005;31:500-5.

8. Singletary SE, Allred C, Ashley P, Basseu LW, Beny D, Bland KI, et al. Revision of the American Joint Committee on Cancer staging system for breast cancer. J Clin Oncol 2002;20:3628-36.

9. Fisher ER, Gregorio RM, Redmond C, Kim WS, Fisher B. Pathologie findings from the national surgical adjuvant breast project (Protocol no. 4). Part III. The significance of extranodal extension of axillary metastases. Am J Clin Pathol 1976;65:439-44.

10. Donegan WL, Stine SB, Samter TG. Implications of extracapsular nodal metastases for treatment and prognosis of breast cancer. Cancer 1993;72:778-82.

11. Leonard C, Corkill M, Tempkin J, Zhen B, Waitz D, Norton L. et al. Are axillary recurrence and overall survival affected by axillary extranodal tumor extension in breast cancer? Implications for radiation therapy. J Clin Oncol 1995;13:47-53.

12. Pierce $U$, Oberman HA, Strawderman MH, Lichter AS. Microscopic extracapsular extension in the axilla: is this an indication for axillary radiotherapy? Int J Radiat Oncol Biol Phys 1995:33:253-9.

13. Fisher BJ, Perera FE, Cooke AL, Opeitum A, Dar AR, Venkatesan VM, et al. Extracapsular axillary node extension in patients receiving adjuvant systemic therapy: an indication for radiotherapy? Int J Radiat Oncol Biol Phys 1997;38:551-9.

14. Vicini FA, Horwitz EM, Lacema MD, Brown DM, White J, Dmuchowski CF. et al. The role of regional nodal irradiation in the management of patients with early-stage breast cancer treated with breastconserving therapy. Int J Radiat Oncol Biol Phys 1997;39:1069-76.

15. Mignano JE, Zahurak ML, Chakravarthy A, Piantadosi S, Dooley WC, Gage L. Significance of axillary lymph node extranodal soft tissue extension and indications for postmastectomy irradiation. Cancer 1999;86:1258-62.

16. Hetelekidis S, Scbnitt SJ, Silver B, Manola J, Bomstein BA, Nixon AJ, et al. The significance of extracapsular extension of axillary lymph node metastases in early-stage breast cancer. Int J Radiat Oncol Biol Phys 2000;46:31-4.

17. Stitzenberg KB, Meyer AA, Stem SL, Cance WG, Calvo BF, Klauber-DeMore N, et al. Extracapsular extension of the sentinel lymph node metastasis: a predictor of nonsentinel node tumor burden. Ann Surg 2003;237:607-12.

18. Joachim HL, Ratech H. Joachim's lymph node pathology.3rd ed; 2002:539 [see also p. 558].

19. Estourgie SH, Nieweg OE, Valdés Olmos RA. Rutgers ETTh, Kroon BBR. Lymphatic drainage pattern from the breast. Ann Surg 2004:239:232-7. 


\section{Value of Memorial Sloan-Kettering Cancer Center nomogram in clinical decision making for sentinel lymph node-positive breast cancer}

I van den Hoven, GP Kuijt, AC Voogd, MWPM van Beek, RMH Roumen British Journal of Surgery 2010;97:1653-1658

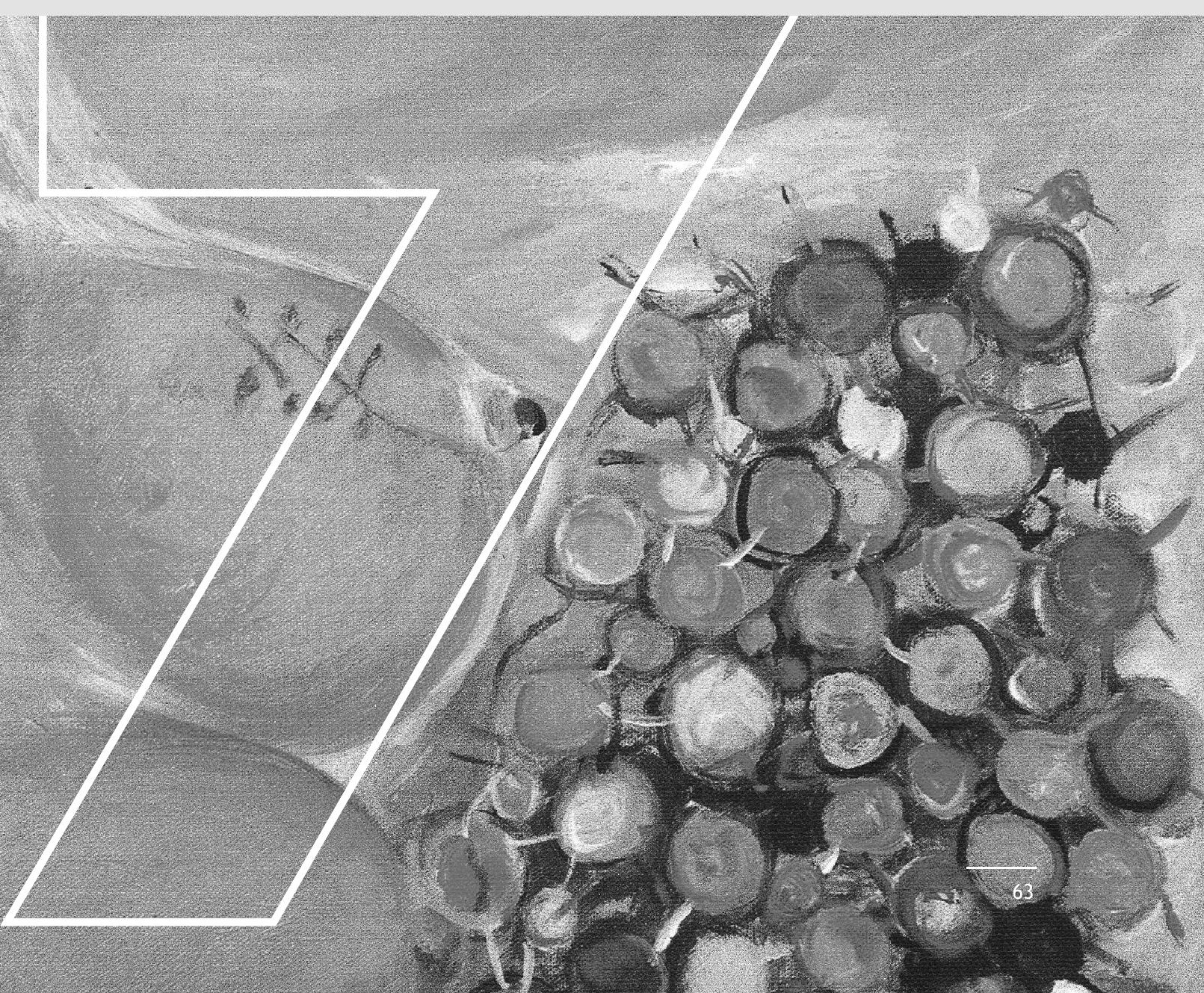




\section{Abstract}

\section{Background}

The aim of this study was to determine the value of the Memorial Sloan-Kettering Cancer Center (MSKCC) nomogram for individual decision making in a Dutch cohort of women with breast cancer with a positive sentinel lymph node (SLN) but at low risk of additional nodal metastases.

\section{Methods}

Data were collected on 168 patients with a positive SLN who underwent completion axillary lymph node dissection. The predicted probability of non-SLN metastases was calculated for each patient, using the MSKCC nomogram. Specificity and false-negative rates were calculated for subgroups with a predicted risk of no more than 5, 10 or $15 \%$. A receiver operating characteristic (ROC) curve was constructed and the area under the curve (AUC) calculated.

\section{Results}

The discrimination of the MSKCC nomogram, measured by the AUC, was 0.68 . For low predicted probability cut-off values of no more than 5,10 and $15 \%$, the false-negative rates were 20, 14 and $19 \%$, and the specificities were 4, 27 and $32 \%$, respectively. The low-risk category ( $5 \%$ or less) consisted of only $3.0 \%$ of the study population.

\section{Conclusion}

The performance of the MSKCC nomogram was insufficient to make it a useful tool for individual decision making in this cohort of women with SLN-positive breast cancer. 


\section{Introduction}

Axillary lymph node status is the most important prognostic indicator for women with breast cancer ${ }^{1}$. Sentinel lymph node biopsy (SLNB) has become the standard method of assessment of regional lymph node involvement in breast cancer. There is general agreement now that there is no need to perform a further axillary lymph node dissection (ALND) if the sentinel lymph node (SLN) is negative on histopathology. When the SLN is positive, an additional completion ALND is recommended for further staging of the axilla and to maintain local tumour control ${ }^{2}$. Whether completion ALND is necessary for every patient with detected SLN metastases remains questionable. Up to $70 \%$ of women with a positive SLN have no additional non-SLN metastases ${ }^{3}$. This means that a substantial number of women undergo ALND without obvious therapeutic benefit or additional staging information ${ }^{4}$, but with potential morbidity. Therefore, it is desirable to identify patients with a positive SLN who are at very low risk of having additional non-SLN metastases and for whom it may be justified not to carry out completion ALND.

The Memorial Sloan-Kettering Cancer Center (MSKCC) was the first to develop a nomogram to predict the likelihood of additional (non-sentinel) nodal metastases in patients with a previous positive SLNB. This nomogram predicts individual risk on the basis of a multivariable logistic regression model containing eight variables ${ }^{5}$. The aim of the present study was to determine whether the MSKCC nomogram was useful for individual decision making in a Dutch cohort of women with breast cancer.

\section{Methods}

The study included all patients with primary breast cancer who had a successful SLNB between January 2000 and December 2008 at the Máxima Medical Centre in Veldhoven and fulfilled the following conditions: a clinically negative axilla; no previous systemic treatment; radiotherapy of the breast or ipsilateral axillary surgery; diagnosed with histopathologically proven SLN metastases and subsequently underwent completion ALND. Data collected for each patient included age, and histopathological data about the primary tumour, SLNs and lymph nodes removed during ALND. Specific data concerning the variables used in the MSKCC nomogram were also collected and included: tumour type, pathological size in centimetres, nuclear grade, presence of lymphovascular invasion in the tumour, multifocality, oestrogen receptor status of the tumour, method of detection of SLN metastases, and the number of positive and negative SLNs. 
Table 7.1 Reasons for excluding patients from the study.

\begin{tabular}{lc}
\hline & No. of patients \\
\hline No completion ALND & 32 \\
Micrometastases or isolated tumour cells in SLN & 15 \\
Solitary positive parasternal SLN & 3 \\
Co-morbidity & 14 \\
Previous systemic treatment & 3 \\
Repeat SLN biopsy & 8 \\
Non-categorizable morphology & 5 \\
Missing data & 3 \\
Metastases in afferent vessel of SLN & 1 \\
Total & 52 \\
\hline
\end{tabular}

ALND, axillary lymph node dissection; SLN, sentinel lymph node.

\section{Sentinel lymph node identification and surgery}

The SLNB procedure was performed using a combined colorimetric and radioisotope technique using patent blue and $99 \mathrm{~m}$ Tc-labelled colloidal albumin (Solco R/Nanocoll $\circledast$; Sorin Biomedica Diagnostics, Vercelli, Italy) as described previously ${ }^{6}$. All SLNs harvested during surgery were sent for pathological assessment. Intraoperative frozen-section analysis was not undertaken routinely for operational reasons.

\section{Histopathological assessment}

Small SLNs (less than $0.3 \mathrm{~cm}$ ) were embedded completely in paraffin without bisection. Larger lymph nodes $(0.3-0.6 \mathrm{~cm})$ were bisected, and nodes larger than $0.6 \mathrm{~cm}$ were sliced into $0.2 \mathrm{~cm}$ sections and embedded in paraffin. One $4 \mu \mathrm{m}$ slice was taken from each paraffin block and stained with haematoxylin and eosin (routine haematoxylin and eosin).

If a metastasis was found with routine haematoxylin and eosin microscopy, further serial sectioning and immunohistochemistry (IHC) was not performed. Otherwise, each part was step sectioned at three levels at $250 \mu \mathrm{m}$ intervals. At each level one slice was stained with haematoxylin and eosin and another was stained immunohistochemically using Lu5 or AE1/AE3. The method of detection of SLN metastases was recorded in the pathology reports as either routine haematoxylin and eosin or SLN procedure (serial haematoxylin and eosin/IHC). Therefore, it was not possible to distinguish between metastases found by IHC and those identified by serial haematoxylin and eosin analysis so they were evaluated as a single group. When more than one SLN was sent for pathological assessment and the first showed metastases on routine haematoxylin and eosin analysis, no further serial sectioning and IHC was carried out on the other SLNs. All lymph nodes identified at completion ALND were bisected and examined using haematoxylin and eosin. Missing pathological data were obtained by review of the original slides by a specialist breast pathologist. 


\section{Risk assessment and survey}

To calculate the individual risk of additional non-SLN metastases for each patient, the MSKCC nomogram was applied (http://www.mskcc.org/mskcc/html/15 938.cfm).

Where there was a mixed ductal/lobular carcinoma, the individual risk was calculated on the basis of the tumour morphology associated with the poorest outcome.

\section{Nomogram evaluation}

Clinicopathological characteristics of the study population were compared with the prospective MSKCC data set and tested for significance using a $\chi 2$ test. To evaluate the overall discrimination of the MSKCC nomogram, a receiver operating characteristic (ROC) curve was constructed and the area under the curve (AUC) calculated.

For the assessment of accuracy in low-probability subgroups, the population was divided into three groups according to cut-off values for a predicted probability of non-SLN involvement of 5, 10 and $15 \%$ at most. The predicted probabilities were then compared with the actual non-SLN status, and the specificity and false-negative rate were calculated for each group, along with 95\% confidence intervals $(\mathrm{Cl})$. All statistical analyses were performed with SPSS ${ }^{\circledR}$ version 16.0 (SPSS, Chicago, Illinois, USA). $\mathrm{P}<0.050$ was considered statistically significant.

\section{Results}

Of 865 patients with a successful SLNB between January 2000 and December 2008, 220 had metastatic sentinel nodes. Of these, 52 were excluded because they did not fulfil the inclusion criteria, had tumour morphology other than lobular, ductal or mixed, or histopathological data were missing (Table 7.1). The final study population consisted of 168 patients.

The descriptive characteristics of this population and the incidence of non-SLN metastases according to clinicopathological characteristics are listed in Table 7.2. When these characteristics were compared with the MSKCC data from the prospective (validated) group, a significant difference was found for all variables except age and pathological tumour size (Table 7.3). Most patients in the present cohort (84.5\%) had only one positive SLN. A mean of 11.8 (median 11.0) nodes were harvested at ALND and the incidence of additional non-SLN metastases was $34.5 \%$.

The overall discriminatory ability of the MSKCC nomogram, as measured by the AUC, was 0.68 (95\% $\mathrm{Cl} 0.60$ to 0.76 ) (Figure 7.1 ), compared with 0.77 in the original MSKCC study ${ }^{5}$. 
Table 7.2 Descriptive characteristics of the patients and the incidence of non-sentinel lymph node metastases according to clinicopathological characteristics.

\begin{tabular}{|c|c|c|}
\hline & No. of patients & Non-SLN metastasis \\
\hline \multicolumn{3}{|l|}{ Age (years) } \\
\hline$\leq 50$ & 62 (36.9) & $22(35)$ \\
\hline$>50$ & $106(63.1)$ & $36(34.0)$ \\
\hline \multicolumn{3}{|c|}{ Pathological tumour size $(\mathrm{cm})$} \\
\hline$\leq 0.5$ & $4(2.4)$ & $2(50)$ \\
\hline $0.6-1.0$ & $11(6.5)$ & $1(9)$ \\
\hline $1.1-2.0$ & $84(50.0)$ & $26(31)$ \\
\hline $2.1-3.0$ & $51(30.4)$ & $21(41)$ \\
\hline $3.1-5.0$ & $14(8.3)$ & $4(29)$ \\
\hline$>5$ & $4(2.4)$ & $4(100)$ \\
\hline \multicolumn{3}{|c|}{ Tumour type and nuclear grade } \\
\hline Ductal I & $29(17.3)$ & $8(28)$ \\
\hline Ductal II & $74(44.0)$ & $27(36)$ \\
\hline Ductal III & 30 (17.9) & $11(37)$ \\
\hline Lobular & $27(16.1)$ & $11(41)$ \\
\hline Mixed & $8(4.8)$ & $1(13)$ \\
\hline \multicolumn{3}{|c|}{ Lymphovascular invasion } \\
\hline Yes & $26(15.5)$ & $10(38)$ \\
\hline No & $142(84.5)$ & $48(33.8)$ \\
\hline \multicolumn{3}{|l|}{ Multifocal } \\
\hline Yes & $26(15.5)$ & $12(46)$ \\
\hline No & $142(84.5)$ & $46(32.4)$ \\
\hline \multicolumn{3}{|c|}{ Oestrogen receptor status } \\
\hline Negative & 19 (11.3) & $7(37)$ \\
\hline Positive & $149(88.7)$ & $51(34.2)$ \\
\hline \multicolumn{3}{|c|}{ Method of detection } \\
\hline Routine & $109(64.9)$ & $46(42.2)$ \\
\hline Serial H\&E/IHC & $56(33.3)$ & $12(21)$ \\
\hline Frozen section & $3(1.8)$ & $0(0)$ \\
\hline \multicolumn{3}{|c|}{ No. of positive SLNs } \\
\hline 1 & $142(84.5)$ & $43(30.3)$ \\
\hline 2 & $22(13.1)$ & $11(50)$ \\
\hline 3 & $2(1.2)$ & $2(100)$ \\
\hline 4 & $1(0.6)$ & $1(100)$ \\
\hline 5 & $0(0)$ & $0(0)$ \\
\hline 6 & $1(0.6)$ & $1(100)$ \\
\hline \multicolumn{3}{|c|}{ No. of negative SLNs } \\
\hline 0 & $97(57.7)$ & $36(37)$ \\
\hline 1 & $52(31.0)$ & $17(33)$ \\
\hline 2 & $14(8.3)$ & $2(14)$ \\
\hline 3 & $3(1.8)$ & $2(67)$ \\
\hline 4 & $2(1.2)$ & $1(50)$ \\
\hline
\end{tabular}

Values in parentheses are percentages. SLN, sentinel lymph node; H\&E, haematoxylin and eosin; IHC, immunohistochemistry. 
Table 7.3 Comparison of the present data and Memorial Sloan-Kettering Cancer Center prospective data.

\begin{tabular}{|c|c|c|c|}
\hline & Present cohort & $\begin{array}{c}\text { MSKCC } \\
\text { Prospective population }\end{array}$ & $\mathrm{P}^{*}$ \\
\hline Age (years) & & & 0.255 \\
\hline$\leq 50$ & $62(36.9)$ & $157(42.1)$ & \\
\hline$>50$ & $106(63.1)$ & $216(57.9)$ & \\
\hline Pathological tumour size $(\mathrm{cm})$ & & & 0.158 \\
\hline$\leq 0.5$ & $4(2.4)$ & $13(3.5)$ & \\
\hline $0.6-1.0$ & $11(6.5)$ & $49(13.1)$ & \\
\hline $1.1-2.0$ & $84(50.0)$ & $166(44.5)$ & \\
\hline $2.1-3.0$ & $51(30.4)$ & $93(24.9)$ & \\
\hline $3.1-5.0$ & $14(8.3)$ & $41(11.0)$ & \\
\hline$>5.0$ & $4(2.4)$ & $11(2.9)$ & \\
\hline Tumour type and nuclear grade & & & $<0.001$ \\
\hline Ductal I & $29(17.3)$ & $11(2.9)$ & \\
\hline Ductal II & $74(44.0)$ & $175(46.9)$ & \\
\hline Ductal III & 30 (17.9) & $129(34.6)$ & \\
\hline Lobular & $27(16.1)$ & $58(15.5)$ & \\
\hline Mixed & $8(4.8)$ & $0(0)$ & \\
\hline Lymphovascular invasion & & & $<0.001$ \\
\hline Yes & $26(15.5)$ & $219(58.7)$ & \\
\hline No & $142(84.5)$ & $154(41.3)$ & \\
\hline Multifocal & & & $<0.001$ \\
\hline Yes & $26(15.5)$ & $241(64.6)$ & \\
\hline No & $142(84.5)$ & $132(35.4)$ & \\
\hline Oestrogen receptor status & & & 0.003 \\
\hline Negative & $19(11.3)$ & $83(22.3)$ & \\
\hline Positive & $149(88.7)$ & $290(77.7)$ & \\
\hline Method of detection & & & $<0.001$ \\
\hline Routine H\&E & 109 (64.9) & $23(6.2)$ & \\
\hline Serial H\&E/IHC & $56(33.3)$ & - & \\
\hline Serial H\&E & - & $40(10.7)$ & \\
\hline IHC only & - & $18(4.8)$ & \\
\hline Frozen section & $3(1.8)$ & $273(73.2)$ & \\
\hline Frozen section not done & $165(98.2)$ & $19(5.1)$ & \\
\hline No. of positive SLNs & & & 0.009 \\
\hline 1 & $142(84.5)$ & $265(71.0)$ & \\
\hline 2 & $22(13.1)$ & $75(20.1)$ & \\
\hline 3 & $2(1.2)$ & $21(5.6)$ & \\
\hline 4 & $1(0.6)$ & $8(2.1)$ & \\
\hline 5 & $0(0)$ & $3(0.8)$ & \\
\hline 6 & $1(0.6)$ & $0(0)$ & \\
\hline 7 & $0(0)$ & $0(0)$ & \\
\hline$\geq 8$ & $0(0)$ & $1(0.3)$ & \\
\hline No. of negative SLNs & & & $<0.001$ \\
\hline 0 & $97(57.7)$ & $132(35.4)$ & \\
\hline 1 & $52(31.0)$ & 79 (21.2) & \\
\hline 2 & $14(8.3)$ & $72(19.3)$ & \\
\hline 3 & $3(1.8)$ & $41(11.0)$ & \\
\hline 4 & $2(1.2)$ & 22 (5.9) & \\
\hline 5 & $0(0)$ & 7 (1.9) & \\
\hline 6 & $0(0)$ & $10(2.7)$ & \\
\hline 7 & $0(0)$ & $2(0.5)$ & \\
\hline 8 & $0(0)$ & $8(2.1)$ & \\
\hline
\end{tabular}

Values in parentheses are percentages. MSKCC, Memorial Sloan-Kettering Cancer Center; H\&E, haematoxylin and eosin; IHC, immunohistochemistry; SLN, sentinel lymph node. ${ }^{*} \chi_{2}$ test. 


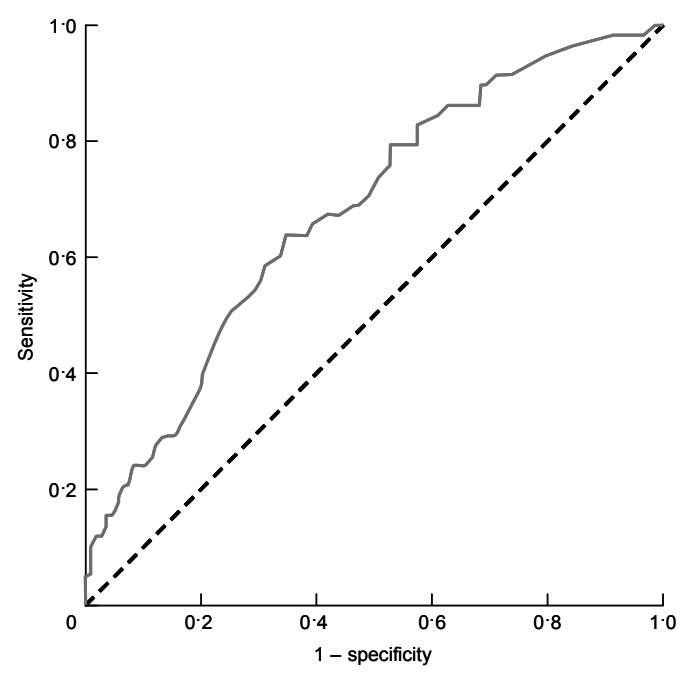

Figure 7.1 Receiver operating characteristic (ROC) curve for the Memorial Sloan-Kettering Cancer Center nomogram applied to data from the present cohort.

Focusing on the subgroups with a low risk of non-SLN metastases according to the MSKCC nomogram, the absolute number of patients who might avoid a completion ALND was small (Table 7.4). For each subgroup the predicted probability was compared with the actual non-SLN status, and the specificity and false-negative rates were calculated (Table 7.4).

Table 7.4 Memorial Sloan-Kettering Cancer Center model applied to patient subgroups with at most 5, 10 or $15 \%$ predicted probability of an involved non-sentinel lymph node.

\begin{tabular}{lcccc}
\hline $\begin{array}{l}\text { Predicted probability of } \\
\text { non-SLN metastases (\%) }\end{array}$ & No. of patients* & True negative ${ }^{\dagger}$ & False negative ${ }^{\dagger}$ & Specificity (\%) \\
\hline$\leq 5$ & $5(3.0)$ & $4(80 ; 30,99)$ & $1(20 ; 11,70)$ & $4(0,7)$ \\
$\leq 10$ & $35(20.8)$ & $30(86 ; 69,95)$ & $5(14 ; 5,31)$ & $27(19,36)$ \\
$\leq 15$ & $43(25.6)$ & $35(81 ; 66,91)$ & $8(19 ; 9,34)$ & $32(23,41)$ \\
\hline
\end{tabular}

Values in parentheses are ${ }^{*}$ percentages based on all 168 patients, $\dagger$ percentages with $95 \%$ confidence intervals and $\$ 95 \%$ confidence intervals. SLN, sentinel lymph node.

\section{Discussion}

Since the introduction of SLNB, many authors have tried to define a subgroup of SLNpositive patients for whom a completion ALND can safely be omitted. Several nomograms and other predictive tools have been developed to help in this decision. 
The MSKCC nomogram seems to be the most promising and has been validated by numerous centres with an AUC varying between 0.58 and $0.84^{3,7-18}$.

Patients with a low predicted probability of additional non-SLN metastases are the group of interest, as they might decline completion ALND. For this group, the true risk of additional non-SLN metastases should be comparable to the false-negative rate of the SLN procedure: lower than $10 \%$ and preferably under $5 \%{ }^{19}$. It is obvious that this discussion is not relevant for patients with an intermediate to high risk of non-SLN metastases.

Many surgeons would consider omitting completion ALND at a predicted probability $5 \%$ or less, although older age and co-morbidity could lead to a higher threshold for completion ALND.

In this study the discriminating power of the MSKCC nomogram was low, with an AUC of 0.68 . More importantly, the group of patients at low risk ( $5 \%$ or less) of non-SLN metastases was very small (3.0\%). This low predicted proportion should be contrasted with the high chance of a negative non-SLN axilla in this cohort $(65.5 \%)$. The falsenegative rate was higher than expected but comparable to that reported by Cserni $(11-16 \%)^{20}$. Therefore, application of the MSKCC nomogram in this cohort was neither clinically relevant nor reliable for the most important subset of patients.

In the original MSKCC population, 140 patients were excluded because a completion ALND was not performed ${ }^{5}$. A later analysis showed that most of these patients belonged to the group with a low predicted probability, with nomogram scores of no more than $10 \%{ }^{21}$. This potential selection bias could be one of the reasons why the prediction for the low-probability group was inaccurate; half of the excluded patients had micrometastatic disease or isolated tumour cells in the SLN (Table 6.1). A study by Alran and colleagues ${ }^{4}$ showed that the AUC for patients with micrometastases was 0.54 ( $95 \% \mathrm{Cl} 0.42$ to 0.65 ), suggesting that in this subgroup the nomogram is no better than tossing a coin ${ }^{4}$.

Another possible reason why the MSKCC nomogram was found to be less reliable in this cohort is that the general population characteristics differed significantly from those of the MSKCC population.

Some practical difficulties were encountered when trying to calculate the individual risk for each patient using the MSKCC nomogram. First, nuclear grade is one of the three components (nuclear grade, proliferation index and tube formation) on which histological grade is based. Nuclear grade is less commonly recorded in pathology reports, which may lead to confusion and less reliable calculation ${ }^{4,7,9}$. Second, five patients had other than ductal or lobular morphology such as tubular, mucinous or carcinoid carcinomas, whereas eight patients had a mixed lobular/ductal carcinoma. 
The nomogram has no instruction on how to handle this. Furthermore the ratio of positive to negative sentinel nodes is an important variable. As described in the methods, only routine haematoxylin and eosin analysis was used for the other SLNs when the first sentinel node showed metastases on routine haematoxylin and eosin staining. This is a widely accepted procedure in the Netherlands. If step sectioning and IHC had been performed routinely, there would probably have been more positive $\mathrm{SLNs}^{22}$ and thus higher MSKCC-predicted probabilities. This does mean that the lowprobability group would have become even smaller. Finally, as mentioned in other studies, it is most likely that in different practical (pathology) settings, the size of the SLN metastases rather than the method of detection is a more reliable and consistent variable. The dependence of the MSKCC nomogram on local practices limits its general applicability $7,8,9,12,14,15,18$.

The clinical question that physicians and patients are faced with when a positive SLN is discovered at final pathology must be answered with the most evidence based knowledge available. A nomogram seems to give a better estimate than the clinical opinion of doctors ${ }^{16}$. The performance of the MSKCC nomogram was not good enough to make it a useful tool in individual decision making for the present cohort of patients with SLN-positive breast cancer, but a low predicted risk of non-SLN metastases. Obviously better nomograms are needed, possibly with regional or national bias to account for local population characteristics. 


\section{REFERENCES}

1. Fisher B, Bauer M, Wickerham DL, Redmond CK, Fisher ER, Cruz AB et al. Relation of number of positive axillary nodes to the prognosis of patients with primary breast cancer. An NSABP update. Cancer 1983;52:1551-1557.

2. Richtlijn mammacarcinoom, Nationaal Borstkanker Overleg Nederland (NABON), 2008; http://www.oncoline.nl [accessed 21 June 2010].

3. Coutant C, Olivier C, Lambaudie E, Fondrinier E, Marchal F, Guillemin F et al. Comparison of models to predict nonsentinel lymph node status in breast cancer patients with metastatic sentinel lymph nodes: a prospective multicenter study. J Clin Oncol 2009;27:2800-2808.

4. Alran S, De Rycke Y, Fourchotte V, Charitansky H, Laki F, Falcou MC et al. Validation and limitations of use of a breast cancer nomogram predicting the likelihood of non-sentinel node involvement after positive sentinel node biopsy. Ann Surg Oncol 2007;14:2195-2201.

5. Van Zee KJ, Manasseh DM, Bevilacqua JL, Boolbol SK, Fey JV, Tan LK et al. A nomogram for predicting the likelihood of additional nodal metastases in breast cancer patients with a positive sentinel node biopsy. Ann Surg Oncol 2003;10:1140-1145.

6. Roumen RM, Geuskens LM, Valkenburg JG. In search of the true sentinel node by different injection techniques in breast cancer patients. Eur J Surg Oncol 1999;25:347-351.

7. Degnim AC, Reynolds C, Pantvaidya G, Zakaria S, Hoskin T, Barnes S et al. Nonsentinel node metastases in breast cancer patients: assessment of an existing and a new predictive nomogram. Am J Surg 2005;190:543-550.

8. Klar M, Jochmann A, Stumpf M, Foeldi M, Gitsch G, Stickeler E et al. The MSKCC nomogram for predicting the likelihood of non-sentinel node involvement in a German breast cancer population. Breast Cancer Res Treat 2008;112:523-531.

9. Kocsis $L$, Svébis $M$, Boross $G$, Sinkó $M$, Maráz R, Rajtár $M$ et al. Use and limitations of a nomogram predicting the likelihood of non-sentinel node involvement after a positive sentinel node biopsy in breast cancer patients. Am Surg 2004;70:1019-1024.

10. Kohrt HE, Olshen RA, Bermas HR, Goodson WH, Woud DJ, Henry S et al. New models and online calculator for predicting non-sentinel lymph node status in sentinel lymph node positive breast cancer patients. BMC Cancer 2008;8:66.

11. Lambert LA, Ayers GD, Hwang RF, Hunt KK, Ross MI, Kuerer HM et al. Validation of a breast cancer nomogram for predicting nonsentinel lymph node metastases after a positive sentinel node biopsy. Ann Surg Oncol 2006;13:310-320.

12. Pal A, Provenzano E, Duffy SW, Pinder S, Purushotham AD. A model for predicting non-sentinel lymph node metastatic disease when the sentinel lymph node is positive. Br J Surg 2008;95:302-309.

13. Ponzone R, Maggiorotto F, Mariani L, Jacomuzzi ME, Magistris A, Mininanni $P$ et al. Comparison of two models for the prediction of nonsentinel node metastases in breast cancer. Am J Surg 2007; 193:686-692.

14. Smidt ML, Kuster DM, van der Wilt GJ, Thunnissen FB, van Zee KJ, Strobbe LJ. Can the Memorial Sloan-Kettering Cancer Center nomogram predict the likelihood of nonsentinel lymph node metastases in breast cancer patients in the Netherlands? Ann Surg Oncol 2005;12:1066-1072.

15. Soni NK, Carmalt HL, Gillett DJ, Spillane AJ. Evaluation of a breast cancer nomogram for prediction of non-sentinel lymph node positivity. Eur J Surg Oncol 2005;31:958-964.

16. Specht MC, Kattan MW, Gonen M, Fey J, van Zee KJ. Predicting nonsentinel node status after positive sentinel lymph biopsy for breast cancer: clinicians versus nomogram. Ann Surg Oncol 2005; 12: 654-659.

17. Zgajnar J, Perhavec A, Hocevar M, Podkrajsek M, Hertl K, Frkovic-Grazio S et al. Low performance of the MSKCC nomogram in preoperatively ultrasonically negative axillary lymph node in breast cancer patients. J Surg Oncol 2007;96:547-553.

18. Van la Parra RF, Ernst MF, Bevilacqua JL, Mol SJ, van Zee KJ, Broekman JM et al. Validation of a nomogram to predict the risk of nonsentinel lymph node metastases in breast cancer patients with a positive sentinel node biopsy: validation of the MSKCC breast nomogram. Ann Surg Oncol 2009; 16:1128-1135. 
19. Schwartz GF, Giuliano AE, Veronesi U. Consensus Conference Committee. Proceedings of the consensus conference on the role of sentinel lymph node biopsy in carcinoma of the breast, April 19-22, 2001, Philadelphia, Pennsylvania. Cancer 2002;94:2542-2551.

20. Cserni G. Comparison of different validation studies on the use of the Memorial Sloan-Kettering Cancer Center nomogram predicting nonsentinel node involvement in sentinel node-positive breast cancer patients. Am J Surg 2007;194:699-700.

21. Park J, Fey JV, Naik AM, Borgen PI, van Zee KJ, Cody HS III. A declining rate of completion axillary dissection in sentinel lymph node-positive breast cancer patients is associated with the use of a multivariate nomogram. Ann Surg 2007;245:462-468.

22. Dowlatshahi K, Fan M, Snider HC, Habib FA. Lymph node micrometastases from breast carcinoma: reviewing the dilemma. Cancer 1997;80:1188-1197. 


\section{A head to head comparison of nine tools predicting non-sentinel lymph node status in sentinel node positive breast cancer women}

GP Kuijt, I vd Hoven, RMH Roumen, EW Steyerberg, Y Vergouwe Submitted

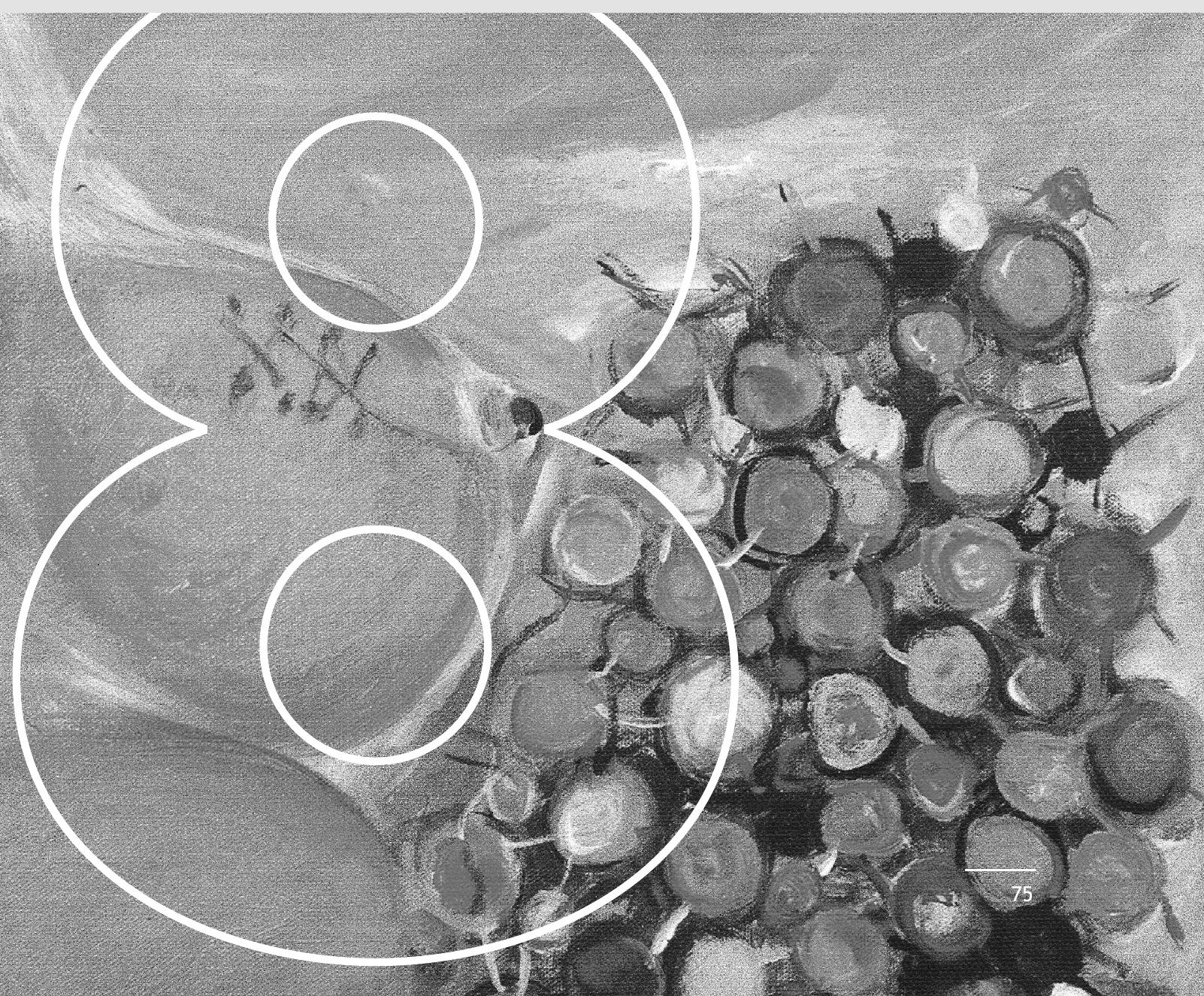




\section{Abstract}

\section{Purpose}

The purpose of this study was to evaluate the performance of currently available tools predicting non-sentinel lymph node status in women with sentinel node positive breast cancer and to see if they can be safely used in everyday clinical practice.

\section{Methods}

We analysed data from 857 women with primary breast cancer who successfully underwent a SLNB at Máxima Medical Center in the Netherlands between 2000-2008. Tools evaluated were: the nomograms from Memorial Sloan Kettering Cancer Center, Stanford, Mayo, Cambridge, Gur, and MOU, and the scores from Saidi, Tenon, and MDA. Model performance was assessed using calibration (validation plot with calibration slope and intercept), discrimination (area under the receiver operating characteristic curve, AUC) and Nagelkerke's explained variation. Moreover, the subgroup with a predicted risk under $10 \%$ was separately analysed.

\section{Results}

The MSKCC nomogram showed best overall performance with best discrimination (AUC 0.69), second best calibration, and highest explained variation (31\%). The $10 \%$ low risk threshold led to defining only $22 \%$ (38/176) of the women as being low risk while in fact $66 \%(116 / 176)$ were non-SLN negative. The false negative rate was $13 \%$ (5/38).

\section{Conclusions}

The existing models predicting non-SLN metastasis in SLNB positive breast cancer patients are not yet ready for implementation in general practice. Further research efforts should improve model performance in selecting low risk patients or, and likely the more promising option, in exploring the possibility of having a role in support of a paradigm shift to a "treat none unless" approach. 


\section{Introduction}

Up to $70 \%$ of women with breast cancer and a positive sentinel lymph node biopsy (SLNB) do not have further non-sentinel lymph node (non-SLN) metastases ${ }^{1}$. This means that completion axillary lymph node dissection (ALND) is frequently unnecessarily performed.

Multiple factors have been associated with non-SLN metastasis such as tumour size, tumour grade, and SLNB metastasis size. Various reputable breast cancer units have combined predictive factors into tools that calculate the likelihood of non-SLN metastasis for individual patients ${ }^{2-10}$. These tools can potentially be used to select patients with a low risk of having non-SLN metastases. If the risk is low enough, ALND may be avoided. An important question is whether these tools can consistently select low risk patients and whether these tools are safe to use in daily practice.

In this paper, we report a head to head comparison of nine tools predicting the risk of non-SLN metastasis using a single centre cohort of breast cancer patients who underwent SLNB and ALND. The subgroup with a predicted risk under $10 \%$ was separately analysed.

\section{Patients and methods}

All women treated for primary breast cancer at Máxima Medical Centre (MMC) between 2000-2008 who underwent a successful SLNB were eligible for this study ${ }^{11}$. The MMC is a 609 bed non-academic teaching hospital near Eindhoven in the SouthEastern Netherlands.

Sentinel lymph nodes were identified using combined patent blue and 99mTc-labelled colloidal albumin. All blue, hot, or enlarged lymph nodes were harvested and sent in for pathological analysis. Intraoperative frozen-section analysis was not undertaken for logistical reasons. ALNDs were performed in a separate procedure after pathological examination of the SLNB.

Pathological analysis of the SLNB started with a bi-sectioned haematoxylin and eosin (H\&E) staining. If no metastasis was found, further serial sectioning at $250-\mu \mathrm{m}$ intervals and immune-histochemical (IHC) staining was performed. The method of metastasis detection was reported as found either with routine H\&E staining or by SLNB procedure, meaning both serial sectioning as well as IHC staining. When more than one lymph node was included in the SLNB specimen and the first H\&E staining showed metastasis, then no further serial sectioning or IHC staining was performed. All ALND lymph nodes were bi-sectioned and examined using H\&E staining only. 
Missing pathological data were obtained by review of the original slides by a specialist breast pathologist ${ }^{12}$. In eight patients missing data was imputated.

\section{Prediction tools}

We evaluated six nomograms and three scoring systems that predict the risk of nonSLN metastasis in patients with positive SLNB: the nomograms from Memorial Sloan Kettering Cancer Centre, Stanford, Mayo, Cambridge, Gur, and MOU, and the scores from Saidi, Tenon, and MDA $^{2-10}$. Each prediction tool uses a different set of common clinico-pathologic variables. The majority include tumour size, lymph vascular invasion, and the size of the SLNB metastasis (Table 8.1). The nomograms provide predicted risks on a continuous scale, apart from the Mou nomogram that has 6 risk categories. The scores provide 2 (Saidi), 6 (MDA) or 12 (Tenon) grades of predicted risks. Each tool was applied to each individual in order to calculate the individual risk of non-SLN metastases. We had complete data for all women analysed.

\section{Statistical model evaluation}

Calibration, discrimination, and explained variation were assessed for the nine prediction tools and presented in a validation plot. Calibration is the agreement between observed and predicted outcomes. Thus, the predicted risk of non-SLN metastasis as calculated by the prediction tool is compared to the observed frequencies of non-SLN metastasis and graphed in a validation plot. A line was drawn through all points. The ideal calibration line has a slope of 1.0, meaning that the line runs upward at a 45-degree angle. A calibration line intercept different from 0.0 can be an indication that predictions are systematically too high or too low.

Model discrimination refers to the ability of a model to correctly distinguish a patient who has non-SLN metastasis from a patient who does not. Essentially this indicates whether the relative ranking of individual predictions is in the correct order. Discrimination is quantified as the area under the receiver operating characteristic (ROC) curve, which plots true positives vertically versus false positives horizontally.

Overall performance was assessed using Nagelkerke's explained variation $\left(R^{2}\right) \cdot R^{2}$ is an overall quality tool that includes both measures of calibration and discrimination and so quantifies the amount of information in a model. 
Nine tools predicting non-sentinel lymph node status

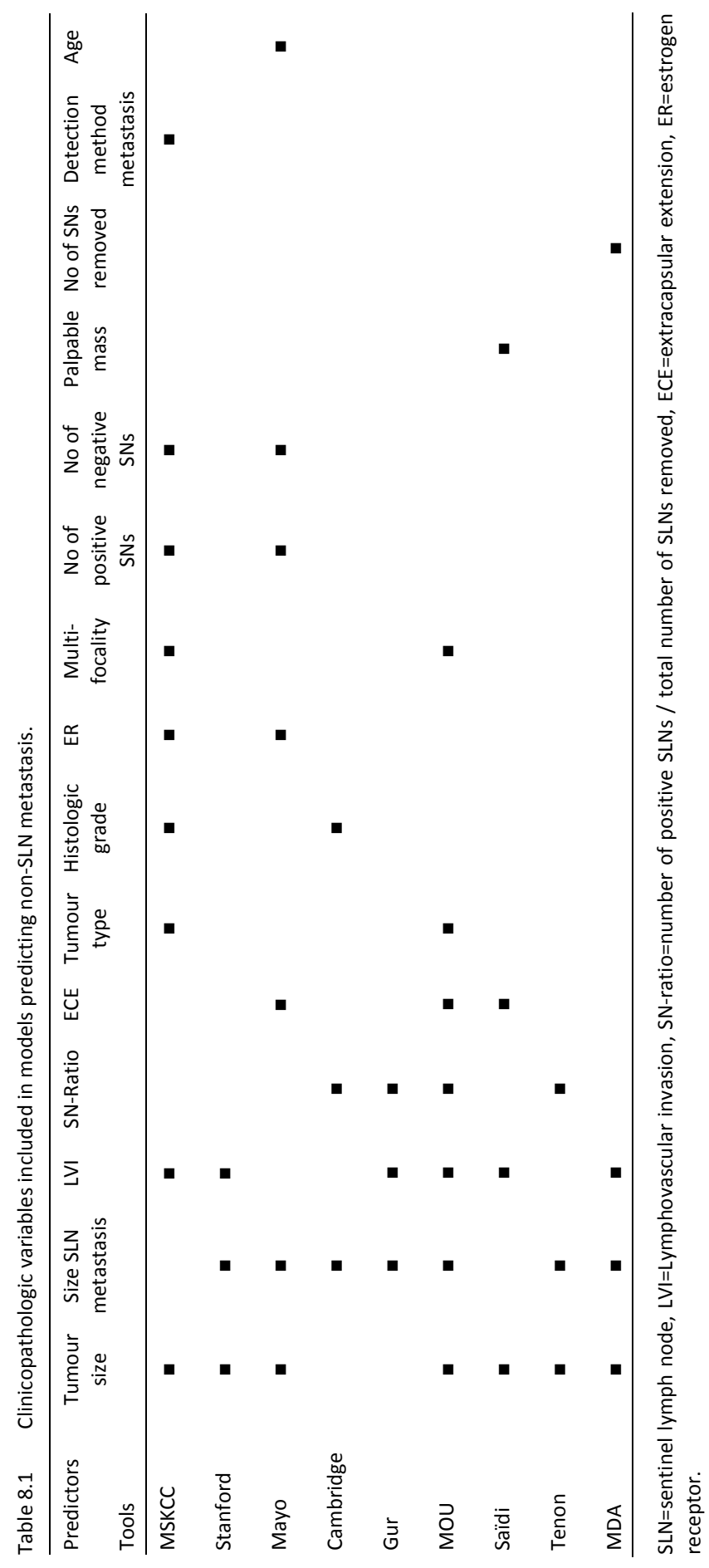




\section{Clinical usefulness}

We defined low risk to be a less than $10 \%$ risk of non-SLN metastasis, similar to others $^{1,13}$. Women with a predicted risk lower than $10 \%$ were classified as not having non-SLN metastasis and in whom an ALND thus could safely be avoided. We assessed how many women were identified as being low risk (true negatives) by each tool and how many of these low risk women actually had non-SLN metastasis (false negative rate).

Analyses were performed with $\mathrm{R}$ (version 2.8.1; $\mathrm{R}$ foundation for Statistical Computing, Vienna, Austria).

\section{Results}

There were 220 women with SLNB metastases among the 857 patients with primary breast cancer who successfully underwent a SLNB between 2000-2008 at the Máxima Medical Centre. After excluding 44 patients who for various reasons did not undergo ALND, 176 patients with a positive SLNB and ALND were available for analysis.

Non-SLN metastases were found in 60/176 (34\%) women and 116/176 (66\%) women had no further non-SLN metastasis. Most of the women had palpable tumours (145/176), had tumours smaller than $3 \mathrm{~cm}$ (155/176), and were treated with breast conserving therapy (147/176). One sixth (29/176) had multifocal tumour growth with tumour size defined as the single largest dimension. Nearly 85\% (149/176) of the women had only a single positive sentinel lymph node. Almost two thirds (113/176) had a macrometastasis, defined as a metastasis greater or equal than $2 \mathrm{~mm}$ in size. Only 3\% (6/176) had metastasis smaller than $0.2 \mathrm{~mm}$ or isolated tumour cells. This low number can be explained by the fact that a ALND is generally not indicated when the SLNB contains only submicrometastasis. In these patients, ALND was done because of other clinico-pathologic characteristics or because of patient preference. The median number of lymph nodes harvested at ALND was 11, indicating that the ALND was qualitatively well done (Table 8.2). 
Table 8.2 Patient population characteristics $n=176$.

\begin{tabular}{|c|c|c|}
\hline & $\mathrm{n}$ & $\%$ \\
\hline \multicolumn{3}{|l|}{ Age } \\
\hline$\leq 50$ & 67 & 38 \\
\hline$>50$ & 109 & 62 \\
\hline Median (range) & $54(34-89)$ & \\
\hline \multicolumn{3}{|l|}{ Palpable tumour } \\
\hline Yes & 145 & 82 \\
\hline No & 31 & 18 \\
\hline \multicolumn{3}{|l|}{ Type of surgery } \\
\hline Breast conserving & 147 & 84 \\
\hline Mastectomy & 29 & 16 \\
\hline \multicolumn{3}{|l|}{ Pathological tumour size $(\mathrm{cm})$} \\
\hline$\leq 0.5$ & 5 & 3 \\
\hline $0.6-1.0$ & 11 & 6 \\
\hline $1.1-2.0$ & 86 & 49 \\
\hline $2.1-3.0$ & 53 & 30 \\
\hline $3.1-5.0$ & 17 & 10 \\
\hline$>5.0$ & 4 & 2 \\
\hline \multicolumn{3}{|l|}{ Tumour type } \\
\hline Invasive ductal carcinoma & 136 & 77 \\
\hline Invasive lobular carcinoma & 27 & 15 \\
\hline Mixed + other & 13 & 7 \\
\hline \multicolumn{3}{|l|}{ Lymphovascular invasion } \\
\hline Yes & 28 & 16 \\
\hline No & 148 & 84 \\
\hline \multicolumn{3}{|l|}{ Tumour grade } \\
\hline Grade 1 & 58 & 33 \\
\hline Grade 2 & 84 & 48 \\
\hline Grade 3 & 28 & 16 \\
\hline Unknown & 6 & 3 \\
\hline \multicolumn{3}{|l|}{ Multifocal } \\
\hline Yes & 29 & 16 \\
\hline No & 147 & 84 \\
\hline \multicolumn{3}{|l|}{ Estrogen-receptor status } \\
\hline Negative & 20 & 11 \\
\hline Positive & 155 & 88 \\
\hline Unknown & 1 & 1 \\
\hline \multicolumn{3}{|l|}{ Progesterone-receptor status } \\
\hline Negative & 37 & 21 \\
\hline Positive & 138 & 78 \\
\hline Unknown & 1 & 1 \\
\hline \multicolumn{3}{|l|}{ Her2Neu status } \\
\hline Negative & 79 & 45 \\
\hline Positive & 11 & 6 \\
\hline Unknown & 86 & 49 \\
\hline \multicolumn{3}{|l|}{ No. of positive SLN } \\
\hline 1 & 149 & 85 \\
\hline 2 & 23 & 13 \\
\hline 3 & 2 & 1 \\
\hline 4 & 1 & 1 \\
\hline 5 & 0 & 0 \\
\hline 6 & 1 & 1 \\
\hline
\end{tabular}


Table 8.2 (continued)

\begin{tabular}{lcc}
\hline & $\mathrm{n}$ & $\%$ \\
\hline Ratio of metastatic SNs to total SNs & & 58 \\
Median ratio (range) & $1.00 .20-1.00)$ & 34 \\
1 & 102 & 9 \\
$0.5-1$ & 59 & 3 \\
$<0.5$ & 15 & 31 \\
Classification of SN metastases & & 64 \\
Submicrometastasis & 55 & 1 \\
Micrometastasis & 113 & 15 \\
Macro metastasis & 2 & 84 \\
Unknown & & 1 \\
Extracapsular extension & 26 & \\
Yes & 148 & 65 \\
No & 2 & 35 \\
Unknown & & 34 \\
Method of detection & 115 & 66 \\
Routine & 61 & \\
Serial H\&E/IHC & 60 & \\
ALND & 116 & \\
Positive & Median $11(2-27)$ & \\
Negative & & \\
Median nr of lymph nodes harvested (range) & & \\
\hline
\end{tabular}

The validation plot of the MSKCC nomogram makes the best general impression (Figure 8.1). The calibration line is closest to the ideal line, and the deciles of grouped observations are well distributed along the line. Slope was 0.70 with a line intercept of 0.14 . The Mayo nomogram has the best slope $(0,74)$ and intercept $(-0.08)$ but the deciles fall further from the line with no decile in the low risk range. The Cambridge plot has a slope of 0.67 but the deciles are more scattered. On the other end, the MDA score and Stanford nomogram have the lowest slopes (0.19 and 0.25) while the Saidi score is an outlier with a slope of -0.14 . The Gur and Mou nomograms have midrange slopes $(0.44$ and 0.49 ) with most of the Gur deciles in the low risk area.

Discrimination, estimated as area under the curve (AUC) of the receiver operating characteristic curve, varied from 0.69 for the MSKCC nomogram to 0.61 for the MDA score (Figure 8.1). The Saidi score was again an outlier (AUC 0.53). The Stanford nomogram has second best discrimination (AUC 0.66) and the Mayo and Mou nomograms are tied for third (AUC 0.65).

Overall performance, represented by Nagelkerke's explained variation $\left(R^{2}\right)$, varied substantially between the predictive tools with values between $31 \%$ for the MSKCC nomogram and $14 \%$ for the Gur model. The Saidi score is once again an outlier at $-7 \%$. 
MSKCC

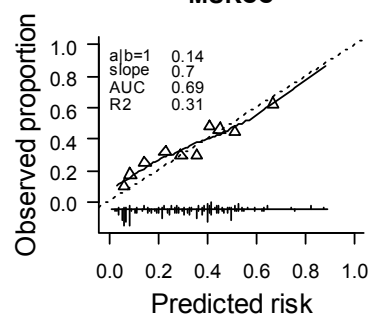

Cambridge

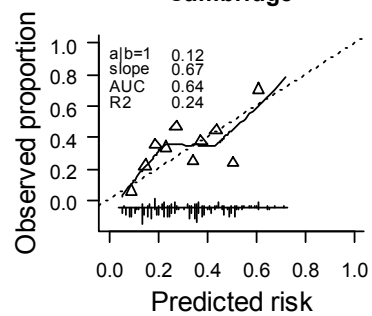

Saidi

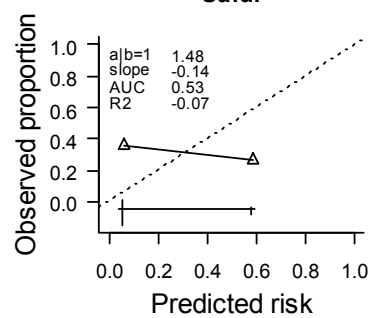

Stanford

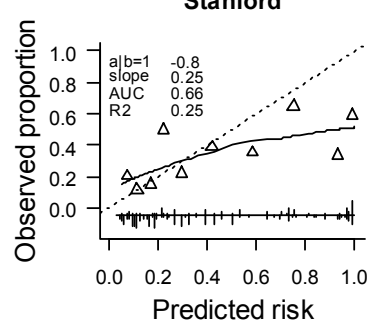

Gur

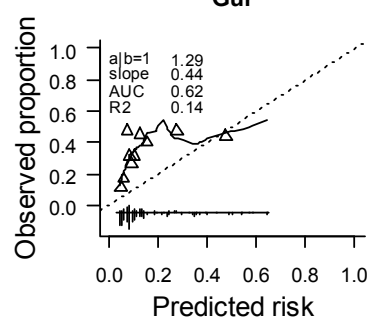

Tenon

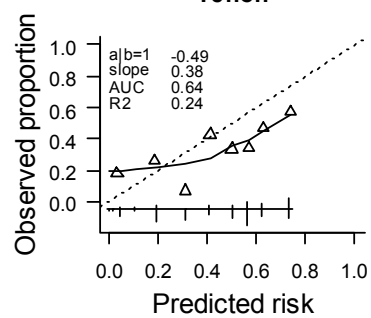

Mayo

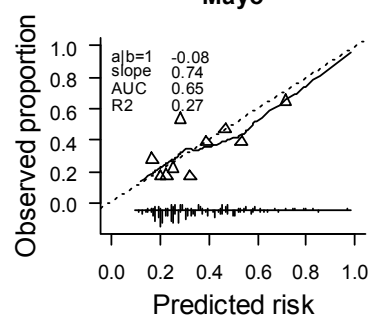

Mou

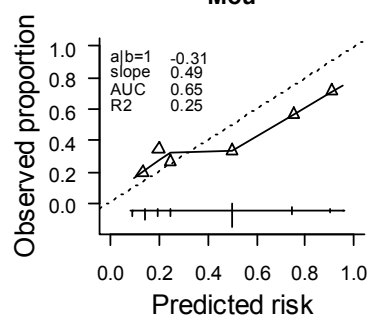

MDA

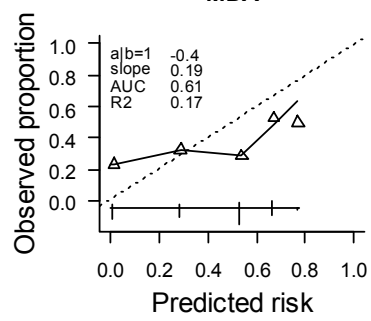

Figure 8.1 Validation plot of tools predicting non-SLN status in patients with SLNB metastasis. The $a / b=1$ is the $x$-intercept when the line angle is set at 1 (dotted line). Both $a / b=1$ and slope are measures of calibration. AUC is the area under the receiver operating characteristic curve, a measure of discrimination. Explained variation (R2) contains elements of both calibration and discrimination and is an overall quality measure. The horizontal line at the bottom of the graph shows the density distribution of the predicted values. Spikes above this line indicate women with non-SLN metastasis; spikes below the line indicate women without non-SLN metastasis.

At a $10 \%$ low risk threshold, the Cambridge and MOU nomograms had the lowest false negative rate ( $8 \% ; 1 / 13$ women) but only labelled $12 / 116(10 \%)$ of the women as being low risk (Table 8.3). Thus only a few ALNDs would have been avoided. The MSKCC nomogram has the next lowest false negative rate. Here 38/116 (33\%) women were classified as low risk with 33/38 (87\%) correctly classified and 5/38 (13\%) incorrectly classified. The Gur model classified 95/116 (82\%) women as low risk but had a false negative rate of $26 \%$ (25/95). Finally, the Mayo model found none of the women to be low risk. 
Table 8.3 Number of patients in whom ALND would have been avoided in the hypothetical situation that the predictive models had been used.

\begin{tabular}{lccc}
\hline Prediction tool & $\begin{array}{c}\text { No. of SLNB positive } \\
\text { patients predicted to be } \\
\text { non-SLN negative. }\end{array}$ & $\begin{array}{c}\text { No. of patients correctly } \\
\text { classified as non-SLN } \\
\text { negative. }\end{array}$ & $\begin{array}{c}\text { No. of patients in which } \\
\text { non-SLN metastasis would } \\
\text { have been missed. }\end{array}$ \\
\hline MSKCC & $38 / 176(22 \%)$ & $33 / 116(28 \%)$ & $5 / 38(13 \%)$ \\
Stanford & $22 / 176(13 \%)$ & $18 / 116(16 \%)$ & $4 / 22(18 \%)$ \\
Mayo & $0 / 176(0 \%)$ & $0 / 116(0 \%)$ & $0(0 \%)$ \\
Cambridge & $13 / 176(7 \%)$ & $12 / 116(10 \%)$ & $1 / 13(8 \%)$ \\
Gur & $95 / 176(54 \%)$ & $75 / 116(65 \%)$ & $25 / 95(26 \%)$ \\
MOU & $13 / 176(7 \%)$ & $12 / 116(10 \%)$ & $1 / 13(8 \%)$ \\
Saïdi & $34 / 176(19 \%)$ & $25 / 116(22 \%)$ & $9 / 34(26 \%)$ \\
Tenon & $49 / 176(28 \%)$ & $38 / 116(33 \%)$ & $11 / 49(22 \%)$ \\
MDA & $43 / 176(24 \%)$ & $33 / 116(28 \%)$ & $10 / 43(23 \%)$ \\
\hline
\end{tabular}

Total population $n=176,60$ with and 116 without non-SLN metastasis, risk threshold electively set at $10 \%$.

\section{Discussion}

In this comparison of nine tools predicting the risk of non-SLN metastasis in SLNB positive breast cancer women, the MSKCC nomogram had the best discrimination, satisfactory calibration, and best overall performance. Close runners up were the Cambridge model and the Mayo model, although the latter is not usable for our purposes because predicted risks were all above the $10 \%$ threshold. The purpose of these predictive models is to support the selection of individual women with a low risk of non-SLN metastasis who can safely avoid ALND. Ideally, such a system identifies all patients with axillary metastasis (high sensitivity) and classifies also patients without a metastasis correctly (high specificity).

Several studies, including a recent meta-analysis, have validated tools predicting nonSLN metastases ${ }^{1,3-5,14-23}$. Our results of a single centre are in line with these earlier publications. The current study distinguishes itself in its comprehensive assessment of the major currently available prediction tools with multiple model performance measures, i.e. calibration (calibration plots), discrimination (area under the receiver operating characteristic curve $[A \cup C]$ ) and explained variation (Nagelkerke's $R^{2}$ ). Further a subgroup of low risk women was studied.

The AUC is the most common and often only measure reported evaluating predictive tool performance, see, for example, the recent meta-analysis by Zhu et al. ${ }^{23}$. This quantification of discrimination, i.e. whether the relative ranking of individual predictions is in the correct order, does not necessarily reflect the accuracy of a predictive tool and does not correlate well to clinical practice ${ }^{1,24}$. When is the AUC high enough to be of reliable use? The MSKCC tool showed in our data the highest 
discriminative ability with an AUC of 0.69 . This means that the odds are roughly two to one that the MSKCC nomogram will correctly predict which of two random SLNB positive women will have non-SLN metastasis.

Calibration is another important aspect of model performance, but much less frequently reported in predictive tool evaluation than discrimination ${ }^{1}$. Calibration reflects the agreement of observed versus predicted outcomes, and is thus also relevant ${ }^{1}$. In our population, the MSKCC and Mayo models had the best calibration. The validation plot (Figure 8.1) for the Mayo model shows that most of the predictions are in the range $20-40 \%$. The predictions of the MSKCC tool are spread more evenly along the line, from risks close to $0 \%$ to about $70 \%$ risk of non-SLN metastases. The wider spread in predicted risk is reflected in a higher AUC.

Prediction models provide results at a continuous scale with a risk of non-SLN metastasis ranging from $0 \%$ to $100 \%$. However, the predictions aim to guide answering a binary question: the patient either has non-SLN metastasis or not. Therefore, the continuous results have to be dichotomized at a chosen threshold. This is central to decision making and is intimately related to the balance between the harm and the benefit of performing a procedure, in this case an ALND after a positive SLNB. In the present study, the threshold was set at an arbitrary value of $10 \%$, based on an intuitively chosen cut off point by experts. Well-informed patients, however, could make their own choice in this matter and then a continuous form of probability would be desirable.

The main goal in using these systems is to harm our patients as little as possible. "Harm" is meant here, as the overall effect of the negative consequences of a particular decision ${ }^{24}$. For patients with a positive SLNB, harm can be done by wrongfully not treating a patient who actually has tumour left in the axilla, or by an unnecessary axillary dissection with its associated morbidity when in fact no rest tumour is present.

The evaluation of harm also depends on the paradigm used. At present this is to "treat all axillae with a positive SLNB with ALND, except". In our study, where the MSKCC system has the best performance, only $33 \%(38 / 116)$ of the possible exceptions were found, with false negative classifications in $13 \%$ (5/38). The Gur nomogram on the other hand, found $82 \%$ (95/116) of the exceptions, however with a very high proportion of false negatives (25/95). We may conclude therefore, that neither of these systems is fit to be used in reliably selecting low risk SLNB positive patients that can safely avoid ALND.

Recently, a paradigm shift was proposed following the results of the $Z 0011$ trial $^{26}$. In this trial, patients with T1-2NOMO breast cancer were treated by SLNB and breast 
conserving therapy. They were randomized into either axillary dissection or no further treatment of the axilla. All patients had whole breast irradiation and were given adjuvant systemic treatment. In the group with ALND, $27 \%$ of the patients had additional metastases in the axillary lymph nodes removed. With a follow up of 6.3 years, the SLNB only group had only a $0.9 \%$ regional lymph node recurrence rate versus a $0.5 \%$ recurrence rate in the ALND group. These findings suggest that not all non-SLN metastases develop into clinically relevant disease. Even though this study excluded all patients with matted nodes, gross extra-nodal disease in the SLNB, as well as patients with three or more involved sentinel lymph nodes, it does seriously challenge the present paradigm of "treat all except" and suggests that it should shift into "treat none unless". This may well mean that prediction models should focus on finding the group of patients with a high probability of having 3 or more positive axillary lymph nodes. Specific attention should then be paid to the group that does not receive radiation, as is mostly the case after ablative surgery.

In conclusion, the performance of nine prediction tools for non-SLN metastasis in SLNB positive breast cancer women varies substantially when applied in a single centre. Only the MSKCC tool may be useful given the reasonable discriminative ability and wider spread in risks, including reliable low risk estimates. Further research efforts should improve prediction model performance in selecting low risk patients or, and likely the more promising option, in exploring the possibility of having a role in support of a paradigm shift to a "treat none unless" approach. 


\section{References}

1. Coutant C, Olivier C, Lambaudie E, Fondrinier E, Marchal F, Guillemin F, et al. Comparison of models to predict nonsentinel lymph node status in breast cancer patients with metastatic sentinel lymph nodes: a prospective multicenter study. J Clin Oncol. 2009;27:2800-2808.

2. Van Zee KJ, Manasseh D-ME, Bevilacqua JLB, Boolbol SK, Fey JV, Tan LK, et al. A nomogram for predicting the likelihood of additional nodal metastases in breast cancer patients with a positive sentinel node biopsy. Ann Surg Oncol. 2003;10:1140-1151.

3. Kohrt HE, Olshen RA, Bermas HR, Goodson WH, Wood DJ, Henry S, et al. New models and online calculator for predicting non-sentinel lymph node status in sentinel lymph node positive breast cancer patients. BMC Cancer. 2008;8:66.

4. Degnim AC, Reynolds C, Pantvaidya G, Zakaria S, Hoskin T, Barnes S, et al. Nonsentinel node metastasis in breast cancer patients: assessment of an existing and a new predictive nomogram. Am J Surg. 2005;190:543-550.

5. Pal A, Provenzano E, Duffy SW, Pinder SE, Purushotham AD. A model for predicting non-sentinel lymph node metastatic disease when the sentinel lymph node is positive. Br J Surg. 2008;95:302-309.

6. Gur AS, Unal B, Ozbek U, Ozmen V, Aydogan F, Gokgoz S, et al. Validation of breast cancer nomograms for predicting the non-sentinel lymph node metastases after a positive sentinel lymph node biopsy in a multi-center study. Eur J Surg Oncol. 2010;36:30-35.

7. Coufal O, Pavlík T, Fabian P, Bori R, Boross G, Sejben I, et al. Predicting non-sentinel lymph node status after positive sentinel biopsy in breast cancer: what model performs the best in a Czech population? Pathol Oncol Res. 2009;15:733-740.

8. Saidi RF, Dudrick PS, Remine SG, Mittal VK. Nonsentinel lymph node status after positive sentinel lymph node biopsy in early breast cancer. Am Surg. 2004;70:101-105.

9. Barranger E, Coutant C, Flahault A, Delpech Y, Darai E, Uzan S. An axilla scoring system to predict nonsentinel lymph node status in breast cancer patients with sentinel lymph node involvement. Breast Cancer Res Treat. 2005;91:113-119.

10. Hwang RF, Krishnamurthy S, Hunt KK, Mirza N, Ames FC, Feig B, et al. Clinicopathologic factors predicting involvement of nonsentinel axillary nodes in women with breast cancer. Ann Surg Oncol. 2003;10:248-254.

11. Máxima Medisch Centrum [Internet]. Wikipedia. [accessed on 12 May 2013]. Link: http://nl.wikipedia.org/w/index.php?title=M\%C3\%A1xima_Medisch_Centrum\&oldid=31513419. 2003.

12. Van den Hoven I, Kuijt GP, Voogd AC, van Beek MWPM, Roumen RMH. Value of Memorial SloanKettering Cancer Center nomogram in clinical decision making for sentinel lymph node-positive breast cancer. Br J Surg. 2010;97:1653-1658.

13. Berrang TS, Lesperance M, Truong PT, Walter C, Hayashi AH, Olivotto IA. Which prediction models best identify additional axillary disease after a positive sentinel node biopsy for breast cancer? Breast Cancer Res Treat. 2012;133:695-702.

14. Klar M, Jochmann A, Foeldi M, Stumpf M, Gitsch G, Stickeler E, et al. The MSKCC nomogram for prediction the likelihood of non-sentinel node involvement in a German breast cancer population. Breast Cancer Res Treat. 2008;112:523-531.

15. Kocsis L, Svébis $M$, Boross G, Sinkó M, Maráz R, Rajtár M, et al. Use and limitations of a nomogram predicting the likelihood of non-sentinel node involvement after a positive sentinel node biopsy in breast cancer patients. Am Surg. 2004;70:1019-1024.

16. Lambert LA, Ayers GD, Hwang RF, Hunt KK, Ross MI, Kuerer HM, et al. Validation of a breast cancer nomogram for predicting nonsentinel lymph node metastases after a positive sentinel node biopsy. Ann Surg Oncol. 2006;13:310-320.

17. Ponzone R, Maggiorotto F, Mariani L, Jacomuzzi ME, Magistris A, Mininanni $P$, et al. Comparison of two models for the prediction of nonsentinel node metastases in breast cancer. Am J Surg. 2007;193:686-692.

18. Smidt ML, Kuster DM, van der Wilt GJ, Thunnissen FB, Van Zee KJ, Strobbe LJA. Can the Memoria Sloan-Kettering Cancer Center nomogram predict the likelihood of nonsentinel lymph node metastases in breast cancer patients in the Netherlands? Ann Surg Oncol. 2005;12:1066-1072.

19. Soni NK, Carmalt HL, Gillett DJ, Spillane AJ. Evaluation of a breast cancer nomogram for prediction of non-sentinel lymph node positivity. Eur J Surg Oncol. 2005;31:958-964. 
20. Specht MC, Kattan MW, Gonen M, Fey J, Van Zee KJ. Predicting nonsentinel node status after positive sentinel lymph biopsy for breast cancer: clinicians versus nomogram. Ann Surg Oncol. 2005;12: 654-659.

21. Zgajnar J, Perhavec A, Hocevar M, Podkrajsek M, Hertl K, Frkovic-Grazio S, et al. Low performance of the MSKCC nomogram in preoperatively ultrasonically negative axillary lymph node in breast cancer patients. J Surg Oncol. 2007;96:547-553.

22. Van la Parra RFD, Ernst MF, Bevilacqua JLB, Mol SJJ, Van Zee KJ, Broekman JM, et al. Validation of a nomogram to predict the risk of nonsentinel lymph node metastases in breast cancer patients with a positive sentinel node biopsy: validation of the MSKCC breast nomogram. Ann Surg Oncol. 2009;16:1128-1135.

23. Zhu L, Jin L, Li S, Chen K, Jia W, Shan $Q$, et al. Which nomogram is best for predicting non-sentinel lymph node metastasis in breast cancer patients? A meta-analysis. Breast Cancer Res Treat. 2013;137:783-795.

24. Vickers AJ, Cronin AM. Traditional statistical methods for evaluating prediction models are uninformative as to clinical value: towards a decision analytic framework. Semin Oncol. 2010;37: 31-38.

25. Steyerberg EW, Vickers AJ, Cook NR, Gerds T, Gonen M, Obuchowski N, et al. Assessing the performance of prediction models: a framework for traditional and novel measures. Epidemiology. 2010;21:128-38.

26. Giuliano AE, Hunt KK, Ballman KV, Beitsch PD, Whitworth PW, Blumencranz PW, et al. Axillary dissection vs no axillary dissection in women with invasive breast cancer and sentinel node metastasis: a randomized clinical trial. JAMA. 2011;305:569-75. 


\section{Summary, general discussion and future perspectives}

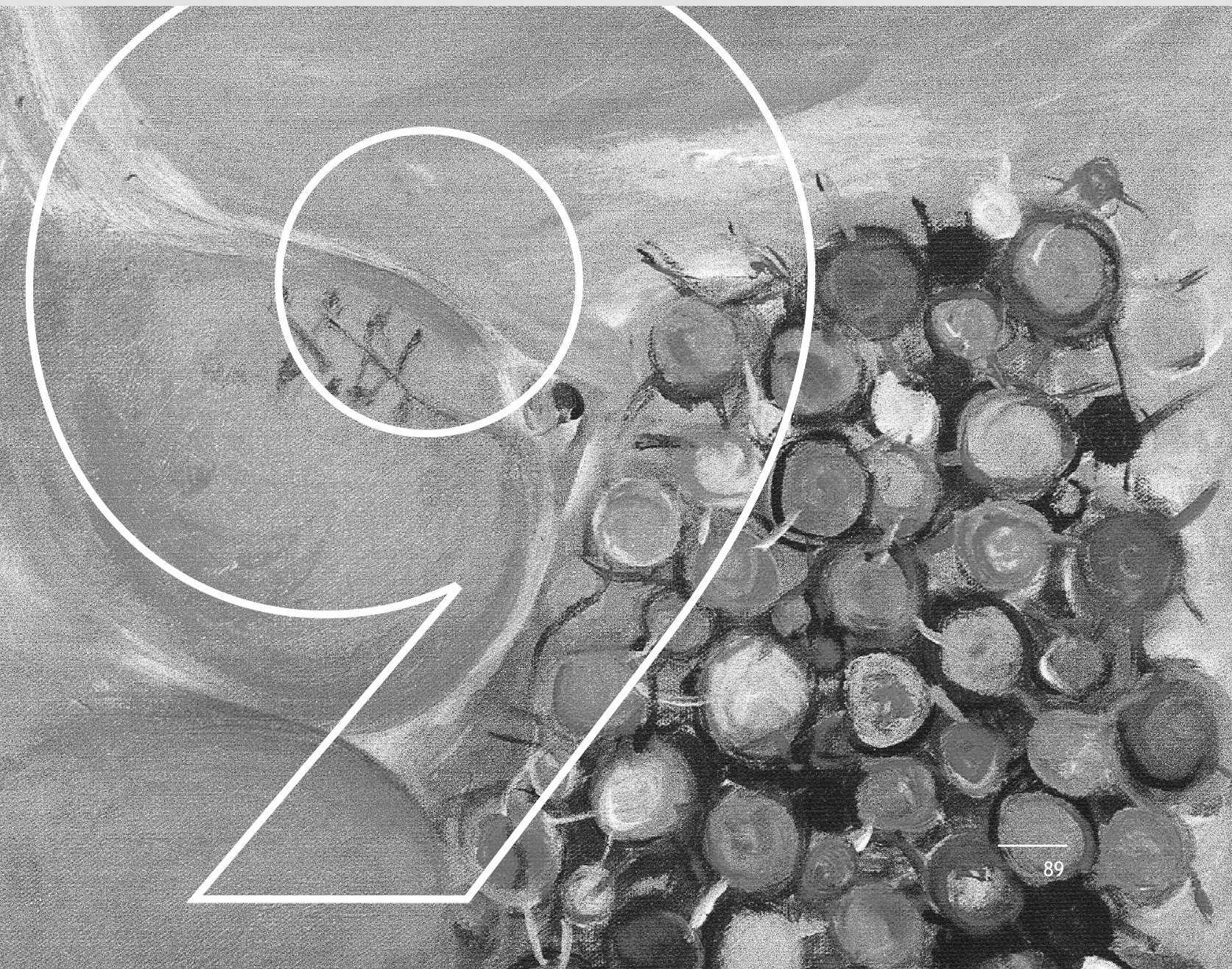


Chapter 9 


\section{Summary, general discussion and future perspectives}

Over the last 50 years, the surgical treatment of breast cancer has become increasingly organ sparing. Not only is the breast conserved whenever possible, but with the introduction of the sentinel node concept, the surgical treatment of the axillary lymph nodes has also become less invasive. This paradigm shift, from standard axillary lymph node dissection for every person with primary breast cancer to the general acceptance of the sentinel node concept, requires evaluation regarding its safety. This thesis presents studies that evaluate this shift from standard axillary lymph node dissection to the sentinel node concept to the widespread use of sentinel node biopsy. The studies presented in the first three chapters evaluate the safety of performing a sentinel node biopsy as the sole procedure in women without sentinel lymph node metastases. The other four chapters contain studies that search for patient groups with sentinel lymph node metastases in which axillary lymph node dissection can be safely avoided.

A general introduction and outline of the thesis is presented in Chapter 1. With the introduction of a new diagnostic procedure, it is of course important to evaluate its safety. Especially of concern when the sentinel node concept was developed was the idea that unrecognized tumour deposits might be left behind in the axilla, possibly resulting in a higher risk of regional relapse of the disease and not being able to identify all patients for whom adjuvant systemic treatment or radiation therapy are needed. Ultimately, such drawbacks might also affect the chances of cure. Therefore, we chose to perform several studies to evaluate patient outcomes to determine if the sentinel node procedure is a safe alternative for the standard axillary lymph node dissection.

Chapter 2 presents the early results of the first 100 sentinel node negative breast cancer patients treated at the Máxima Medical Centre in Veldhoven without axillary lymph node dissection. We also evaluated the morbidity of the sentinel lymph node biopsy procedure by asking our patients to fill in a questionnaire one year after surgery. Median follow up was 24 months during which only one patient developed an axillary recurrence. Regarding the morbidity related to the sentinel node procedure, 12 patients had residual complaints such as scar tenderness, shoulder or arm disability, or new pain after the operation. Two of these 12 women reported having changed their hobbies, sports or daily activities because of the sentinel lymph node biopsy procedure. None of the patients had developed lymphedema or needed post-operative physiotherapy. From the results of this study we concluded that the sentinel lymph node biopsy without further axillary lymph node dissection in patients with sentinel node negative disease promised to be safe and that it could be considered to be the new standard of care for early stage primary breast cancer patients. 
Data collected by the Eindhoven Cancer Registry gave us the opportunity to compare prognosis of breast cancer patients having a negative sentinel node with no further axillary treatment $(n=880)$ to those with negative axillary nodes who had undergone traditional axillary lymph node dissection $(n=1681)$. This study is presented in Chapter 3. As expected, follow-up was shorter in the sentinel node group, with a median of 3.6 years, as compared to a median follow up of 7.7 years in the lymph node dissection group. Five-year overall survival rates were $89 \%$ for the sentinel node patients and $85 \%$ for the lymph node dissection patients. After adjustment for age, tumour size, tumour location, tumour histology, tumour grade, mitotic activity index, hormone receptor status, and local and systemic treatment in multivariate Cox regression analysis, the hazard ratio for overall mortality of patients undergoing lymph node dissection versus those undergoing sentinel node biopsy was 1.23 (95\% confidence interval 0.93-1.64). This shows that early survival after a sentinel node biopsy as a sole procedure is equivalent to the early survival after an extensive lymph node dissection procedure in patients with node-negative breast cancer.

With the passing of time, we became aware that more axillary recurrences had occurred in the first 100 early breast cancer patients with a negative sentinel node, reported in chapter 2 . This gave us reason to return to the patient files of this patient group after a median follow up of 6.5 years, the results of which are reported in Chapter 4. Of the 99 patients for whom follow up was available, 18 had a repeat episode of breast cancer. Five of these patients had developed an ipsilateral axillary recurrence between 14 and 90 months after their sentinel lymph node biopsy procedure. This showed that the risk of axillary recurrence after a sentinel node only procedure is higher than originally reported and that it was a misconception to think that axillary recurrences will only occur within the first few years after diagnosis.

In Chapter $\mathbf{5}$ we changed our focus of study to breast cancer patients with positive axillary lymph nodes. In the early sentinel lymph node biopsy era, it was hypothesized that patients with small sized, so called micrometastases might have a more favourable prognosis than those with macrometastases. This was studied using Eindhoven Cancer Registry data. Between 1975 and 1997, 10,111 patients had been diagnosed as having primary breast cancer and who all had undergone conventional axillary lymph node dissection. Three subgroups were compared with respect to overall survival: patients without axillary metastasis (pNO group), patients with only axillary micrometastasis ( $\leq 2 \mathrm{~mm}$, the pN1a group according to TNM classification of 2002 ), and patients with a macrometastsis ( $>2 \mathrm{~mm}$, the pN1 group according to TNM classification of 2002). Being pN1a instead of pNO increased the relative risk of dying by $32 \%$ annually. After accounting for adjuvant systemic treatment, this relative risk increased to 51\%. Similarly, being pN1 instead of pNO increased the risk of dying by $34 \%$ annually, and, after exclusion of the patients using adjuvant systemic treatment, the relative risk increased to $91 \%$. This showed that, based on 25 years of clinical 
practice in general hospitals, having an axillary lymph node metastasis has a significant impact on the chance of dying in any given year during follow-up, and that this unfavourable influence was independent of age or tumour size. Looking at the prognosis, having a lymph node with a "small" micrometastasis was more comparable to having a node with a "large" macrometastasis than it was to having no axillary metastases at all. In interpreting these results, it is important to realize that this study was based on patients treated in the pre sentinel node era and that pathological staining was done with haematoxylin and eosin (H\&E) only, and not with immunohistochemical techniques. As a consequence, small micrometastases could have been missed. From this study we can thus conclude that finding a micrometastasis with $H \& E$ staining is of clinical significance for the patient, and that it will result in a prognosis that is largely similar to the prognosis of a patient with a macrometastasis in one lymph node. However, also in more recent studies, which did include patients in whom micrometastases had been diagnosed by immunohistochemical techniques following sentinel node biopsy, an unfavourable impact of micrometastatic disease on prognosis was observed $^{1,2}$.

Chapter 6 presents a study of patients undergoing axillary lymph node dissection in which we compared the clinico-pathological characteristics between the patients with only one positive lymph node and those with more than one positive lymph node. Again, Eindhoven Cancer Registry data was used to answer this question, and 489 patients with only one positive lymph node and 817 patients with more than one positive axillary lymph node were selected. All patients had undergone complete axillary dissection in the period 1984-2000, not preceded by a sentinel node biopsy. In the univariate and multivariate analysis larger tumour size, more than 15 lymph nodes harvested, the existence of extranodal extension of axillary metastasis, and tumour involvement of the apex of the axilla where found to be positively correlated with having more than one positive axillary lymph node. Interestingly, in light of the study presented in chapter 5 on the prognosis of a micrometastasis, this study found that having a micrometastasis decreased the likelihood of having more than one positive axillary lymph node (odds ratio 0.2 ). Thus, while micrometastasis has a negative influence on survival it seems that finding a micrometastasis makes it more likely that only one axillary lymph node is involved. Findings relevant for the sentinel node era are that tumour size, finding a lymph node with macrometastatic disease and having extranodal extension are positively correlated to having more than one positive axillary lymph node. As axillary clearance is required to know this parameter, the number of lymph nodes harvested cannot be used to identify patients with a positive axillary lymph node in whom axillary lymph node dissection might be safely avoided. The same goes for tumour involvement of the apex of the axilla: the sentinel node is rarely found in the apex, but if it is, then axillary clearance should surely follow, considering the high risk (odds ratio 9.1) of having more than one positive lymph node. In summary, this study shows that tumour size, size of the axillary metastasis, 
and the existence of extranodal extension should all be taken into account if we want to find patients with a positive sentinel node in whom axillary lymph node dissection can be safely avoided.

In 2003, Dr. Kimberly van der Zee and colleagues developed the Memorial SloanKettering Cancer Centre (MSKCC) nomogram, the first predictive system that was able to quantify the risk of additional non-sentinel lymph node metastases for an individual breast cancer patient with a positive sentinel lymph node biopsy. In Chapter 7, we present the performance of the MSKCC nomogram in our own cohort of patients with a positive sentinel node biopsy who subsequently underwent axillary lymph node dissection. There were 168 patients available for analysis, all diagnosed and treated at the Máxima Medical Centre in the Netherlands. The predicted probability of nonsentinel lymph node metastases was calculated for each patient using the online MSKCC risk calculator. The false negative rates of having non-sentinel lymph node metastases at 5, 10, and $15 \%$ risk thresholds was found to be 20,14 , and $19 \%$ respectively. In other words, one in five to seven patients was incorrectly classified as having no additional metastases irrespective of choosing a lower or higher cut off threshold. The specificities at the 5, 10, and $15 \%$ thresholds were 4,27 , and $32 \%$ respectively. Finally, a receiver operating characteristic curve was constructed and the area under the curve was found to be 0.68 . This means that the MSKCC nomogram is only able to correctly discriminate two out of three patients with additional nonsentinel node metastases. Our conclusion is that, based on the performance in this cohort, the MSKCC nomogram is not very useful to make individual treatment decision for our patients with sentinel lymph node positive breast cancer.

Besides the MSKCC nomogram, many other nomograms and scoring systems have become available to predict in which patients with a positive sentinel lymph node, axillary dissection might be safely avoided. Chapter $\mathbf{8}$ is a head to head comparison of nine tools predicting non-sentinel lymph node metastasis in sentinel lymph node biopsy positive breast cancer patients. The systems tested were: the MSKCC nomogram, the Stanford nomogram, the Mayo nomogram, the Cambridge nomogram, the Gur nomogram, the MOU nomogram; and three scoring systems: the Saidi, the Tenon, and the MD Anderson scores. There were 176 primary breast cancer patients available for testing and a predicted probability of having non-sentinel lymph node metastases of $10 \%$ was used. This means that a risk of $10 \%$ or less was considered to be low enough to withhold a complete axillary lymph node dissection. Best calibrated, that is how close predicted outcomes were to the actual outcomes, was the Mayo model, with a line slope on the validation plot of 0.74 compared to the MSKCC nomogram that had a line slope of 0.70 . A perfectly calibrated validation plot has a line slope equal to one. The Mayo model however, was not able to identify any patient with a risk lower than $20 \%$ of having non-sentinel lymph node metastases. Least well calibrated were the Stanford and MD Anderson models. The MSKCC 
nomogram also had the best discrimination, meaning it had the highest likelihood to accurately differentiate between individuals who have non-sentinel lymph node metastasis and those who have not, with an area under the Receiver Operating Characteristic curve of 0.69 . Finally, the MSKCC identified only 38 low risk patients (22\%) with a false negative percentage of $13.2 \%$, where $10 \%$ was to be expected due to the chosen threshold value. We concluded that the MSKCC nomogram performs better than the other available predictive systems, but that none perform well enough to be implemented in general daily practice.

\section{General discussion and future perspectives}

Historically, the surgical treatment of breast cancer involved the breast as well as the ipsilateral axilla. During the last decades, the treatment of both anatomical regions has undergone a paradigm shift. Treatment of the primary breast tumour has evolved from radical mastectomy to breast conserving treatments, while treatment of the axilla has evolved from standard axillary lymph node dissection to routine sentinel lymph node procedures in patients with a clinical negative axilla, confirmed by ultrasound, as a strategy causing clearly less morbidity ${ }^{3-5}$.

Axillary lymph node surgery in breast cancer serves dual purposes. The first is to determine prognosis, because axillary lymph node status is included in decision making for adjuvant systemic therapy and radiation therapy. Secondly, there is the aspect of regional disease control. Breast cancer treatment goals are to maximize patient survival and disease free interval, with as little burden to the patient as possible. The question now and going forward is whether axillary surgery can further be reduced in breast cancer treatment without compromising long term outcome.

Currently, in patients with a clinically negative axilla the use of a sentinel lymph node procedure has been accepted as the gold standard, at least in patients with cT1-2 tumours, without multicentricity and no (recent) axillary surgery. For patients with CT3 tumours the sentinel lymph node procedure may be used, although the yield is relatively low because of the higher nodal involvement rate. Nowadays, axillary ultrasound is routinely used to confirm a clinically node-negative status. In case of positive or doubtful ultrasound findings, cytology or needle biopsy is performed to identify patients with node metastases who should undergo axillary lymph node dissection ${ }^{6}$.

The Z0011 trial is the first and, so far, only trial in which sentinel lymph node positive breast cancer patients were randomized between completion axillary lymph node dissection and a wait-and-see policy ${ }^{7}$. This study demonstrated that after a median follow-up of more than 6 years, the regional recurrence rate was less than $1 \%$ and not 
different between treatment arms. It was concluded that in patients with a low axillary tumour burden, axillary lymph node dissection may no longer be justified. However, the results of the Z0011 trial cannot necessarily be generalized to all sentinel lymph node positive patients, as these concerned selected patients with clinical T1-2 breast cancer, who were all treated with adjuvant systemic therapy and with lumpectomy and tangential-field whole breast radiation therapy that may have involved at least a part of the axilla. It is currently unclear whether omission of completion axillary treatment is safe in patients with more than two positive sentinel lymph nodes, in patients with sentinel node positive disease who undergo mastectomy without radiation therapy, or in patients who undergo partial or modern three-dimensional (3D) radiotherapy after lumpectomy, or in those who do not receive adjuvant systemic therapy.

National statistics on breast cancer treatment in the Netherlands show that our patient population is different from the population in the Z0011 study. In the NABON Breast Cancer Audit (NBCA), it is reported that on average $60 \%$ of patients diagnosed in the years 2011 and 2012 underwent breast-conserving treatment. When breastconserving treatment was applied, then nearly all (98\%) did receive adjuvant radiation therapy, but mostly with modern radiotherapy techniques, including 3D planning. In the Z0011 study, 97\% of patients received adjuvant systemic therapy, most of them also including chemotherapy, whereas in the Netherlands of patients younger than 70 years of age with node-positive breast cancer only $73 \%$ received adjuvant chemotherapy, and of patients older than 70 years only $3 \%$ did in fact receive adjuvant chemotherapy. In patients with ER positive disease who were considered candidates for adjuvant systemic therapy according to the national NABON guidelines, $91 \%$ received adjuvant endocrine therapy. In the overviews of the Early Breast Cancer Trial Co-operative Group, it was shown that adjuvant systemic therapy has a clear impact on locoregional disease control ${ }^{8}$.

Whether axillary irradiation can replace axillary lymph node dissection was the subject of the AMAROS (After Mapping of the Axilla: Radiotherapy Or Surgery?) study, in which patients with sentinel node metastases were randomized between axillary irradiation or lymph node dissection ${ }^{9}$. At a median follow up of 6.1 years, they found no difference in axillary recurrence between the two groups $(0.54 \%$ after axillary lymph node dissection and $1.03 \%$ after radiation). Also, there were no significant differences in overall survival or disease free survival. Of note, a part of these patients had four or more positive lymph nodes that apparently did not have a detrimental outcome from radiotherapy only. Quality of life issues between the two treatment arms were also similar with more lymph oedema in the axillary lymph node dissection group ( $28 \%$ versus $14 \%$ after 5 years), but more shoulder mobility issues in the radiation therapy group. Criticism after presentations at large meetings concerned questions on the size of axillary surgery (often including level III) and on the field of 
radiotherapy (also including level III, supraclavicular field). So, questions that yet have to be addressed are the safety of less extensive radiotherapy on regional recurrence rate and on the occurrence of post radiation fibrosis in the long term.

It was recently proposed to revise the national treatment (NABON) guidelines with respect to axillary treatment, taking the Z0011 study, the AMAROS trial, and observational series such as those included in this thesis into account. The proposal is to withhold completion axillary lymph node dissection in patients with sentinel node micrometastases and with no other unfavourable risk factors and treated with adjuvant systemic therapy (irrespective of breast surgery type). Furthermore, patients with sentinel node micrometastases and additional risk factors or in patients with macro metastases in one to two sentinel nodes without risk factors, who are undergoing breast conserving therapy and adjuvant systemic therapy, may be treated with axillary lymph node dissection or alternatively with level I/II axillary radiotherapy. This amendment is currently being discussed. The proposal is still quite restrictive, because of uncertainties about the protective effect of tangential radiotherapy fields and systemic therapy on axillary recurrence rates in the Z0011 trial. But the trend towards less (axillary) surgery and more systemic treatment and more axillary radiotherapy has been set and is likely to continue.

In the decision-making process towards the patient, the risk of relapse - due to withholding treatment - should be translated in the risk of death. In an EBCTCG metaanalysis on breast radiotherapy it was reported that overall, about one breast cancer death could be avoided by year 15 for every four loco-regional recurrences avoided by year $10^{8}$. If we assume the same holds true for axillary recurrences, and if we would estimate that after 10 years of follow-up in patients with relative favourable primary tumour characteristics and limited sentinel involvement and no further axillary treatment an additional $1 \%$ regional relapse is anticipated, an additional $0.25 \%$ death would occur by year 15 . Or, in other words, in this example the number needed to undergo further axillary treatment is about 400 to prevent one death. That implies that we are currently moving to less surgery to reduce shoulder and arm morbidity, but thereby accepting a small increase in number of deaths.

To support these trends towards less extensive surgery of the axilla and to allow personalized care, we will need prediction models with larger discriminative power than the ones that are currently available. Of all patients with macrometastases in the sentinel node, only $55 \%$ will have metastases in one or more of the remaining (nonsentinel) lymph nodes. This implies that $45 \%$ of all patients with sentinel node macro metastases do not benefit from completion axillary lymph node dissection, but nonetheless suffer from its potential side effects. Moreover, a completion axillary lymph node dissection might also not be necessary for those patients showing a pathologic complete remission to neo-adjuvant systemic therapy. In a recent 
retrospective study in the South-East of the Netherlands, it was shown that $20-42 \%$ of patients, who were treated with neo-adjuvant chemotherapy and with proven axillary involvement at diagnosis, obtained a pathologic complete remission in the axilla ${ }^{10}$. With current available nomograms it is, however, still hard to predict who will have a complete pathological response on systemic therapy and who not.

One way to go to reduce the number of patient needing completion axillary lymph node dissection might be to increase the use of chemotherapy in the neo-adjuvant setting, once the indication for systemic therapy has been set at primary breast cancer diagnosis. Although the reliability of the sentinel node procedure is slightly better when it takes place before neo-adjuvant chemotherapy, there appears to be a potential role for its use after neo-adjuvant chemotherapy ${ }^{11,12}$. This might result in a higher number of sentinel node negative procedures. Increasing the use of neoadjuvant chemotherapy, in combination with delaying the sentinel node procedure until after the end of chemotherapy, may be of benefit for patients with a clinically negative axilla as well as for those with a clinically positive axilla. A potential disadvantage of performing a sentinel lymph node procedure after neo-adjuvant chemotherapy is a lower detection rate and higher false-negative rate, but this may be acceptable in the light of preventing unnecessary axillary lymph node dissection in those with a complete pathological response in the axilla ${ }^{12}$.

With increasing insight into molecular pathways and with increasingly effective systemic therapies, it is expected that more and more patients will no longer need axillary treatment in the future. And with improved predictive systems, we expect that the trend of more personalized care will continue. Further, we may be able to identify patients with clinically negative axillary lymph nodes undergoing breast conserving therapy, who do not benefit from a sentinel lymph node procedure in terms of improved regional recurrence rate through indication for systemic therapy or further regional therapy. In these, the sentinel node procedure may safely be omitted. A prospective randomized trial on this question will start in the Netherlands soon ( $M$. Smidt, personal communication).

In conclusion, the trend towards less invasive surgery in the treatment of early breast cancer patients will likely continue. The next step may be a paradigm shift from the current treatment strategy for the axilla of treating all women with a positive sentinel lymph node by axillary lymph node dissection, except... to a strategy of treating none unless they have other poor prognostic indicators. The latter will be especially likely if the patient will already be receiving adjuvant radiation therapy and/or adjuvant systemic treatment. While more research needs to be done, the trend toward less invasive surgical treatment of the axilla will benefit breast cancer patients everywhere. 


\section{References}

1. De Boer M, van Deurzen CHM, van Dijck JAAM, Borm GF, van Diest PJ, Adang EMM, et al. Micrometastases or isolated tumor cells and the outcome of breast cancer. $\mathrm{N} \mathrm{Engl} \mathrm{J} \mathrm{Med.}$ 2009;361:653-63.

2. Cox CE, Kiluk JV, Riker Al, Cox JM, Allred N, Ramos DC, et al. Significance of sentinel lymph node micrometastases in human breast cancer. J Am Coll Surg. 2008;206:261-8.

3. Zavagno G, De Salvo GL, Scalco G, Bozza F, Barutta L, Del Bianco P, et al. A Randomized clinical trial on sentinel lymph node biopsy versus axillary lymph node dissection in breast cancer: results of the Sentinella/GIVOM trial. Ann Surg. 2008;247:207-13.

4. Schijven MP, Vingerhoets AJJM, Rutten HJT, Nieuwenhuijzen GAP, Roumen RMH, van Bussel ME, e.a. Comparison of morbidity between axillary lymph node dissection and sentinel node biopsy. Eur J Surg Oncol. 2003;29:341-50.

5. Purushotham AD, Upponi S, Klevesath MB, Bobrow L, Millar K, Myles JP, et al. Morbidity after sentinel lymph node biopsy in primary breast cancer: results from a randomized controlled trial. J Clin Oncol. 2005;23:4312-21.

6. Houssami N, Ciatto S, Turner RM, Cody HS 3rd, Macaskill P. Preoperative ultrasound-guided needle biopsy of axillary nodes in invasive breast cancer: meta-analysis of its accuracy and utility in staging the axilla. Ann Surg. 2011;254:243-51.

7. Giuliano AE, Hunt KK, Ballman KV, Beitsch PD, Whitworth PW, Blumencranz PW, et al. Axillary dissection vs no axillary dissection in women with invasive breast cancer and sentinel node metastasis: a randomized clinical trial. JAMA 2011;305:569-75.

8. Early Breast Cancer Trialists' Collaborative Group (EBCTCG), Darby S, McGale P, Correa C, Taylor C, Arriagada $\mathrm{R}$, et al. Effect of radiotherapy after breast-conserving surgery on 10-year recurrence and 15-year breast cancer death: meta-analysis of individual patient data for 10,801 women in 17 randomised trials. Lancet. 2011;378:1707-16.

9. Rutgers EJ, Donker M, Straver ME, Meijnen P, Velde CJHVD, Mansel RE, et al. Radiotherapy or surgery of the axilla after a positive sentinel node in breast cancer patients: Final analysis of the EORTC AMAROS trial (10981/22023). J Clin Oncol [Internet]. 2013 [cited 9 December 2013];31(suppl; abstr LBA1001). Accessed from: http://meetinglibrary.asco.org/content/109779-132.

10. Schipper RJ, Moossdorff M, Nelemans PJ, Nieuwenhuijzen GA, de Vries B, Strobbe LJ, et al. A Model to Predict Pathologic Complete Response of Axillary Lymph Nodes to Neoadjuvant Chemo (Immuno) Therapy in Patients With Clinically Node-Positive Breast Cancer. Clin Breast Cancer. 2014 Jan 3. Epub ahead of print.

11. Van Deurzen CHM, Vriens BEPJ, Tjan-Heijnen VCG, van der Wall E, Albregts M, van Hilligersberg R, et al. Accuracy of sentinel node biopsy after neoadjuvant chemotherapy in breast cancer patients: a systematic review. Eur J Cancer. 2009;45:3124-30.

12. Kuehn T, Bauerfeind I, Fehm T, Fleige B, Hausschild M, Helms G, et al. Sentinel-lymph-node biopsy in patients with breast cancer before and after neoadjuvant chemotherapy (SENTINA): a prospective, multicentre cohort study. Lancet Oncol. 2013;14:609-18. 



\section{Samenvatting}

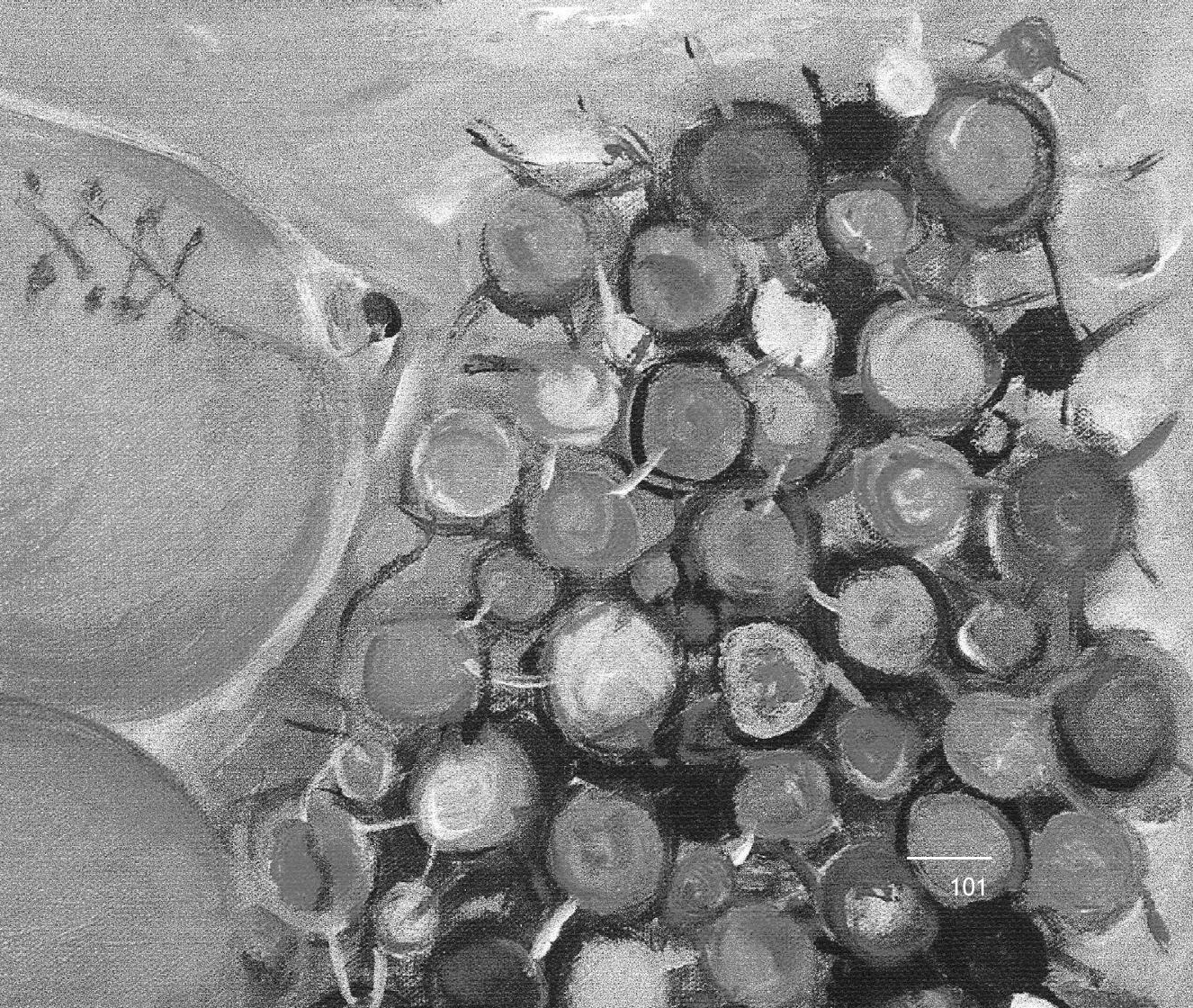




\section{Samenvatting}

De chirurgische behandeling van borstkanker is in de aflopen drie decennia in toenemende mate orgaansparend geworden. Niet alleen wordt de borst zelf vaker gespaard, maar met de komst van de schildwachtklierprocedure is ook de chirurgische behandeling van de oksel minder invasief geworden. $\mathrm{Er}$ is een verschuiving opgetreden van het routinematige verrichten van een okselklierdissectie bij iedere patiënt naar het achterwege laten van deze ingreep bij patiënten met een negatieve schildwachtklier. In dit proefschrift worden studies gepresenteerd over deze verschuiving van standaard een okselklierdissectie naar standaard een schildwachtklier procedure bij het merendeel van de vrouwen met primair borstkanker. De eerste drie studies gaan over de veiligheid van de schildwachtklierbiopsie zonder aanvullende okselklierdissectie bij vrouwen zonder uitzaaiingen in de schildwachtklier. De daarop volgende vier studies richten zich op het vinden van groepen patiënten met uitzaaiingen in de schildwachtklier bij wie een okselklierdissectie mogelijk achterwege gelaten kan worden.

Een algemene introductie en een beschrijving van de opbouw van het proefschrift en de doelstellingen van de verschillende studies worden gepresenteerd in Hoofdstuk 1. De introductie van een nieuwe diagnostische procedure vereist vanzelfsprekend dat de veiligheid ervan wordt geëvalueerd. Met de komst van de schildwachtklierprocedure waren er zorgen dat uitzaaiingen over het hoofd gezien zouden worden en achter konden blijven in de oksel. Deze vrouwen zouden daardoor een hogere kans op een okselrecidief kunnen hebben en daardoor mogelijk onterecht geen adjuvante systeemtherapie of radiotherapie krijgen. Uiteindelijk zou hierdoor eveneens de kans op genezing kleiner kunnen zijn. Om na te gaan of deze zorg terecht is, is een aantal studies gedaan waarin is geëvalueerd of de schildwachtklier procedure een veilig alternatief is voor de routinematige okselklierdissectie van voorheen. De resultaten hiervan worden gepresenteerd in de hoofdstukken 2 tot en met 4.

Hoofdstuk 2 presenteert de uitkomsten van de eerste 100 vrouwen met een negatieve schildwachtklier in het Máxima Medisch Centrum in Veldhoven bij wie geen aanvullend okselklierdissectie is verricht. Daarnaast is er ook gekeken naar de morbiditeit van de schildwachtklierprocedure door middel van een vragenlijst die de vrouwen één jaar na deze ingreep ontvingen. Na een mediane follow up van 24 maanden was bij één patiënt een okselklierrecidief ontstaan. Daarnaast waren er 12 patiënten die een jaar na de schildwachtklierprocedure nog aan de procedure gerelateerde klachten hadden, zoals een gevoelig litteken, functieverlies van schouder of arm, of pijn die na de ingreep ontstaan was. Twee van deze 12 vrouwen hadden hun hobby's, sport of dagelijkse activiteiten moeten aanpassen vanwege de schildwachtklierprocedure. Echter, geen van de vrouwen had lymfoedeem ontwikkeld of gebruik gemaakt van fysiotherapie. Uit deze resultaten concludeerden wij dat een 
negatieve schildwachtklierprocedure zonder aanvullend okselklierdissectie veilig is en minder bijwerkingen geeft dan een okselklierdissectie. Naar onze mening diende de schildwachtklierprocedure de nieuwe standaard te zijn voor het stageren van de oksel bij patiënten met een primair mammacarcinoom.

Het Integraal Kankercentrum (IKZ) te Eindhoven, sinds 1 januari 2014 gefuseerd met het Integraal Kankercentrum Nederland, beschikt over een langlopende kankerregistratie waarin uitgebreide informatie van een groot aantal patiënten is vastgelegd. Dit gaf ons de kans om de prognose van een groep vrouwen met borstkanker met een negatieve schildwachtklierprocedure te vergelijken met een historische controlegroep van vrouwen met een negatieve okselklierstatus na een volledige okselklierdissectie. Deze studie wordt gepresenteerd in Hoofdstuk 3. Omdat de patiënten met een schildwachtklierprocedure in een recentere periode waren behandeld dan de patiënten met een okselklierdissectie was de duur van hun follow-up korter (3,6 jaar versus 7,7 jaar). De 5-jaars overleving was $89 \%$ in de groep met een schildwachtklierprocedure en $85 \%$ in de groep met een okselklierdissectie. Na correctie voor leeftijd, tumorgrootte, tumorlokalisatie, tumorhistologie, tumorgradatie, mitotische activiteit index, hormoonreceptor status en lokale en systemische behandeling in een multivariate Cox regressie analyse bleek het risico op overlijden statistisch niet significant te verschillen tussen de patiënten met een okselklierdissectie en de patiënten met een schildwachtklierprocedure (hazard ratio 1,23; 95\% betrouwbaarheidsinterval 0,93-1,64). Dit resultaat duidt erop dat het achterwege laten van het okselkliertoilet bij patiënten met een negatieve schildwachtklierprocedure niet ten koste gaat van de prognose.

Door de ruimere toepassing van de schilwachtklierprocedure werden chirurgen ook vaker geconfronteerd met patiënten met een okselklierrecidief. Dit was reden om naar de lange termijn resultaten te kijken bij de eerste 100 schildwachtkliernegatieve vrouwen zonder aanvullende okselklierdissectie die ook in Hoofdstuk 2 werden beschreven. De mediane follow-up van deze groep bedroeg inmiddels 6,5 jaar. De resultaten staan beschreven in Hoofdstuk 4. De follow-up was volledig voor 99 van de 100 patiënten. Van hen hadden er 18 opnieuw met borstkanker te maken gekregen. Bij vijf van deze 18 patiënten was sprake van een okselklierrecidief in de behandelde oksel, 14 tot 90 maanden na de schildwachtklierprocedure. Dit laat zien dat het risico op okselklierrecidief bij de schildwachtklierprocedure hoger is dan oorspronkelijk werd gedacht en dat het voorbarig was geweest om op basis van de korte termijn resultaten te veronderstellen dat recidivering alleen in de eerste paar jaar na de behandeling van de oksel plaatsvindt.

In Hoofdstuk 5 wordt de focus van het onderzoek verlegd van de vrouwen zonder uitzaaiingen naar vrouwen met uitzaaiingen in één of meer schildwachtklieren. Deze kleine uitzaaiingen worden aangeduid als micrometastasen. Door de introductie van 
de schildwachtklierprocedure nam het aantal patiënten met micrometastasen toe. Vermoed werd dat de prognose van deze patiënten beter was dan die van patiënten met grotere, zogenaamde macrometastasen in de lymfeklieren. Met deze vraag keerden we terug naar de kankerregistratie van het IKZ waar tussen 1975 en 1999 10.111 patiënten waren geregistreerd met de diagnose primaire borstkanker en die allemaal een okselklierdissectie hadden ondergaan. De overleving van de volgende drie subgroepen werd vergelijken: de groep zonder okselkliermetastasering, de groep met alleen micrometastasen (diameter $\leq 2 \mathrm{~mm}$ ) en de groep met macrometastasen (diameter $>2 \mathrm{~mm}$ ). De groep met micrometastasen had een $32 \%$ hogere kans op overlijden per jaar ten opzichte van de groep zonder okselkliermetastasen en een $52 \%$ hogere kans wanneer uitsluitend gekeken werd naar de patiënten zonder systemische behandeling. Deze risicoverhogingen waren vergelijkbaar met de verhogingen in de groep met macrometastasen die een $34 \%$ hogere kans had op overlijden in vergelijking met de groep zonder okselkliermetastasen en een $91 \%$ hogere kans als de groep met adjuvante systemische therapie buiten beschouwing werd gelaten. We mogen dus concluderen, gebaseerd op 25 jaar praktijkuitkomsten, dat zowel microals macrometastasen de kans op overlijden verhogen. Deze ongunstige invloed op de prognose bleek niet verklaard te worden door verschillen in leeftijd of tumorgrootte. Uitsluitend afgaand op de prognose zou je kunnen zeggen dat het hebben van micrometastasen meer lijkt op het hebben van macrometastasen dan op het afwezig zijn van uitzaaiingen in de lymfeklieren. Deze studie betrof echter uitsluitend vrouwen die een okselklierdissectie hebben ondergaan en geen schildwachtklierprocedure. De kleuring van de lymfeklieren door de patholoog werd bij deze vrouwen uitgevoerd met hematoxyline en eosine en er werd nog geen gebruik gemaakt van moderne technieken zoals immunohistochemische kleuringen. Desalniettemin kunnen we uit deze studie concluderen dat het vinden van een micrometastase met een hematoxyline en eosine kleuring belangrijk is en dat de prognostische betekenis hiervan vergelijkbaar is met het vinden een macrometastase. Enkele recentere studies, waarin wel gebruik gemaakt werd van immunohistochemische kleuring, laten trouwens ook zien dat de prognose van vrouwen met een micrometastase slechter is.

Hoofdstuk 6 van het proefschrift is een studie waarbij de klinische en pathologische eigenschappen van patiënten met één positieve lymfeklier in de oksel vergeleken worden met patiënten die meer dan één positieve klier hebben. Het idee achter deze studie is dat de groep vrouwen met maar één positieve okselklier vergelijkbaar moet zijn met de groep vrouwen met een positieve schildwachtklierprocedure zonder verdere okselkliermetastasering. Ook hier is gebruik gemaakt van IKZ-data waarbij 489 patiënten met maar één positieve okselklier vergeleken zijn met 817 vrouwen met meer dan één positieve okselklier. Alle patiënten ondergingen een okselklierdissectie in de periode 1984-2000. Na het uitvoeren van een univariate en een multivariate analyse werd gevonden dat tumorgrootte, het vinden van meer dan 15 lymfklieren in het okselklierpreparaat, het aanwezig zijn van extranodale groei en een metastase in 
de okseltop allen geassocieerd zijn met het hebben van meer dan één positieve okselklier. Een interessante bevinding, zeker in het licht van de resultaten in Hoofdstuk 5 met betrekking tot prognostische betekenis van micrometastasen, was dat bij detectie van micrometastasen de odds ratio voor het hebben van meer positieve lymfeklieren in de oksel slechts 0,2 was. Hieruit zou geconcludeerd kunnen worden dat het vinden van een micrometastase een negatieve invloed heeft op overleving, maar dat in zo'n geval de kans groot is dat dit de enige lymfeklier is met uitzaaiingen. Bevindingen uit Hoofdstuk 6 die relevant zijn voor het schildwachtkliertijdperk zijn het feit dat de tumorgrootte en het vinden van extranodale groei gecorreleerd zijn met het hebben van meer dan één positieve okselklier. De constatering dat het verwijderen van meer dan 15 lymfeklieren uit de oksel de kans op het hebben van meer dan één positieve lymfeklier vergroot is niet relevant in het kader van de schildwachtklierprocedure. Hetzelfde geldt voor metastasering in de okseltop. De schildwachtklier zit klassiek net lateraal van de rand van de musculus pectoralis major en wordt slechts zeer zelden aangetroffen in de okseltop. Mocht hij hier toch aangetroffen worden en is deze positief, dan zou men vanwege de hoge odds ratio van 9,1 moeten concluderen dat een okselklierdissectie noodzakelijk is. Samenvattend laat deze studie zien dat de tumorgrootte, de afmeting van de metastase in de okselklier en het bestaan van extranodale groei voorspellend zijn voor de kans op het hebben van meer dan één positieve okselklier. Waarschijnlijk zijn deze factoren ook van belang voor het voorspellen van de uitgebreidheid van de uitzaaiingen in de oksel bij patiënten met een positieve schildwachtklierprocedure en het vraagstuk voor wie van hen een aanvullende okselklierdissectie noodzakelijk is.

In 2003 hebben Dr. Kimberley van Zee en haar collegae in het Memorial Sloan Kettering Cancer Center (MSKCC) een instrument ontwikkeld dat gebruik maakt van bekende risicofactoren om bij patiënten met een positieve schildwachtklierprocedure de kans te berekenen op het hebben van nog meer aangetaste lymfeklieren in de oksel. In Hoofdstuk 7 presenteren wij de resultaten van een studie waarbij wij dit MSKCC nomogram toepassen op onze eigen patiënten. Er waren 168 patiënten beschikbaar met een positieve schildwachtklier, allen gediagnosticeerd en behandeld in het Máxima Medisch Centrum in Veldhoven. Het risico op het hebben van nog meer positieve lymfeklieren werd voor elke patiënt berekend met behulp van de online beschikbare MSKCC risico calculator. Er werd gekeken naar het percentage foutnegatieve voorspellingen van het MSKCC nomogram bij verschillende risico-grenzen. Bij een voorspeld risico op het hebben van uitzaaingen buiten de schilwachtklier van $5 \%, 10 \%$ en $15 \%$ bedroeg de kans op een fout-negatieve uitslag respectievelijk $20 \%, 14 \%$ en $19 \%$. Met andere woorden: onafhankelijk van de grens die werd gehanteerd om de laagrisicogroep te definiëren werd één op de vijf á zeven patiënten niet juist geclassificeerd. De specificiteit van het MSKCC nomogram bij de voorspelde risico's van $5 \%, 10 \%$ en $15 \%$ bedroeg respectievelijk $4 \%$, $27 \%$ en $32 \%$. Een receiver operating characteristic curve toonde een oppervlakte onder de curve van 0,68 . Dit 
betekent dat het MSKCC nomogram binnen onze populatie met ruwweg twee derde zekerheid kon vaststellen of een vrouw met voorspeld hoog risico op het hebben van uitzaaiingen elders in de oksel ook daadwerkelijk een hoog risico heeft. Op basis van deze resultaten concluderen we dat het MSKCC nomogram niet goed bruikbaar is op onze poli voor de besluitvorming over de noodzaak voor een aanvullend okselkliertoilet bij individuele patiënten met een positieve schildwachtklierbiopsie.

In navolging van MSKCC nomogram hebben diverse andere onderzoeksgroepen ook een eigen nomogram of systeem ontwikkeld waarmee bij patiënten met een positieve schildwachtklierbiopsie een schatting gemaakt kan worden van de kans op het hebben van verdere okselklieruitzaaiingen. Hoofdstuk 8 beschrijft de resultaten van een studie waarin we de prestaties van negen gepubliceerde systemen met elkaar vergelijken. Dit zijn: het MSKCC nomogram, het Stanford nomogram, het Mayo nomogram, het Cambridge nomogram, het Gur nomogrom en het MOU nomogram. Daarnaast zijn drie score-systemen meegenomen in deze analyse, te weten: de Saidi score, de Tenon score en de MD Anderson score. Voor onze analyse waren 176 patiënten beschikbaar met een primair mammacarcinoom en een positieve schildwachtklierbiopsie. Een laag risico grens van $10 \%$ op het hebben van verdere okselklieruitzaaiingen werd aangehouden. Bij een risico onder de $10 \%$ is het redelijk om een aanvullende okselklierdissectie achterwege te laten, terwijl bij een risico boven de $10 \%$ een okselklierdissectie wel noodzakelijk wordt geacht. Het Mayo nomogram bleek het best gekalibreerd, gevolgd door het MSKCC nomogram. Kalibratie geeft aan hoe goed de voorspelde uitkomsten overeenkomen met de werkelijke uitkomsten. Een ideale kalibratie heeft een 1 op 1 relatie tussen voorspelling en uitkomst. Hoewel het Mayo nomogram ten aanzien van kalibratie het best presteerde bleek het in onze praktijk niet bruikbaar omdat er geen enkele patiënt was bij wie de kans op het hebben van verdere okselklieruitzaaiingen volgens dit nomogram lager was dan 20\%. Het slechts gekalibreerd waren het Stanford nomogram en de MD Anderson score. Het MSKCC nomogram bezat het grootste discriminerende vermogen. Discriminatie is een maat voor de kans dat een voorspellend systeem juist differentieert tussen een patiënt met een hoog risico en een patiënt met een laag risico op aanvullende okselkliermetastasering. Discriminatie wordt gekwantificeerd met de oppervlakte onder de receiver operating characteristic curve (AUC). Het MSKCC nomogram had een AUC van 0,69. Uiteindelijk classificeerde het MSKCC nomogram 38 patiënten als "laag risico", met een fout-negatief percentage van $13,2 \%$. De conclusie luidde dat de MSKCC nomogram de beste eigenschappen bezit van de beschikbare voorspellende systemen maar dat de prestaties nog niet goed genoeg zijn om gebruikt te kunnen worden in de dagelijkse praktijk. 


\section{Algemene bespreking en aanbevelingen}

De chirurgische behandeling van borstkanker bestaat uit behandeling van de borst alsmede de behandeling van de gelijkzijdig gelegen oksel. Gedurende de laatste decennia heeft zowel de behandeling van de borst als van de oksel een aantal grote veranderingen ondergaan. Bij het verwijderen van de primaire tumor is een verschuiving opgetreden van de radicale mastectomie naar borstsparende technieken, terwijl in de behandeling van de axilla de standaard routinematige okselklierdissectie bij een groot deel van de patiënten is vervangen door de schildwachtklierprocedure. Deze ontwikkelingen hebben geleid tot minder klachten in arm en schouder.

Het doel van het chirurgisch ingrijpen in de oksel is tweeledig. Allereerst dient het om een uitspraak te kunnen doen over de prognose en zo te bepalen of een aanleiding is voor het geven van systemische therapie of radiotherapie. Daarnaast dient het chirurgisch ingrijpen in de oksel om de ziekte regionaal onder controle te houden. Algemene doelen van de behandeling zijn het maximaliseren van overlevingkans en, als genezing niet mogelijk is, de progressie van de ziekte zo lang mogelijk uit te stellen. Dit doel wil men bereiken met zo weinig mogelijk aan de behandeling gerelateerde klachten voor de patiënt. De vraag nu en voor de toekomst is of de chirurgie van de oksel nog verder gereduceerd kan worden zonder dat dit ten koste gaat van de genezingskans van de patiënten met borstkanker. Momenteel is de schildwachtklierprocedure de gouden standaard bij de behandeling van patiënten met tumoren van vijf centimeter of kleiner (cT1-2) zonder multicentriciteit en zonder recente chirurgische ingreep in het okselgebied. Bij grotere tumoren mag ook een schildwachtklierprocedure verricht worden, hoewel de opkomst van de schildwachtklier met behulp van de radio-actieve tracer lager is dan bij kleinere tumoren. Ook is het in Nederland inmiddels gebruikelijk om een echografisch onderzoek van de oksel te verrichten om pre-operatief te bevestigen dat er sprake is van een negatieve oksel. Als op de echografisch beelden verdachte afwijkingen worden gevonden kan een echogeleide cytologische punctie van die afwijkingen worden verricht, waarbij na een positieve uitslag direct overgegaan kan worden tot een okselklierdissectie.

Een belangrijke recente ontwikkeling op het gebied van de behandeling van patiënten met een positieve schildwachtklierbiopsie zijn de resultaten van de Amerikaanse Z0011 trial. In deze studie werden borstsparend behandelde patiënten met een positieve schildwachtklier gerandomiseerd tussen een aanvullende okselklierdissectie en een afwachtend beleid. De resultaten waren opmerkelijk. Na een mediane follow up van meer dan 6 jaar bedroeg de kans op een okselrecidief slechts $1 \%$ en deze kans verschilde niet tussen beide behandelgroepen. De resultaten van de $Z 0011$ trial geven aan dat het misschien niet langer nodig is om een aanvullende okselklierdissectie uit te voeren bij schildwachtklierpositieve patiënten met een verder gunstig profiel. Een gunstig profiel wordt dan gedefinieerd als patiënten met een cT1-2 tumor die ook 
adjuvante systemische therapie krijgen en die behandeld zijn met borstsparende ingreep aangevuld met radiotherapie van de borst, waarbij in ieder geval de onderkant van de oksel in het bestralingsveld ligt. Op basis van de resultaten van de Z0011 trial kan niet geconcludeerd worden of een okselklierdissectie ook achterwege gelaten kan worden bij patiënten met twee of meer positieve schildwachtklieren, patiënten die een mastectomie hebben ondergaan zonder aanvullend radiotherapie of patiënten die na borstsparende behandeling bestraald zijn met moderne technieken, zoals partiële of 3-dimensionele radiotherapie. Ook is op basis van de Z0011 resultaten niet vast te stellen wat de invloed is geweest van de adjuvante systemische behandeling op de regionale controle.

De Nederlandse populatie borstkankerpatiënten met een positieve schildwachtklierbiopsie verschilt van de patiënten die zijn behandeld in de Z0011 studie. De NABON Breast Cancer Audit laat zien dat in Nederland gemiddeld $60 \%$ van de borstkankerpatiënten tussen 2011-12 een borstsparende behandeling heeft ondergaan, waarna vervolgens bij $98 \%$ van deze patiënten aanvullende radiotherapie is toegepast. In de Z0011 studie kreeg 97\% van alle patiënten adjuvante systemische therapie, meestal bestaand uit chemotherapie. Dit is ook anders dan bij ons in Nederland, waar maar $73 \%$ van de vrouwen met een positieve schildwachtklier jonger dan 70 jaar adjuvante chemotherapie hebben gekregen en waar slechts $3 \%$ van de patiënten ouder dan 70 jaar adjuvante chemotherapie heeft gekregen. Van de vrouwen met hormoonreceptorpositieve ziekte heeft 91\% adjuvante endocriene therapie gekregen. Dit is belangrijk omdat de Early Breast Cancer Trial Co-operative groep laat zien dat adjuvante systeemtherapie een duidelijke invloed heeft op locoregionale controle.

Of de behandeling van de oksel bij borstkanker zou kunnen bestaan uit radiotherapie in de plaats van chirurgie is onderzocht in de AMAROS trial (After Mapping of the Axilla: Radiotherapy or Surgery). In deze studie werden patiënten met een positieve schildwachtklier biopsie gerandomiseerd tussen bestraling van de oksel of aanvullende okselklierdissectie. Na een mediane follow up van 6,1 jaar was er geen verschil in de kans op een okselklierrecidief tussen beide groepen: 0,54\% na okselklierdissectie en $1,03 \%$ na radiotherapie van de oksel. Ook was er geen sprake van een verschil in de totale overleving en de ziektevrije overleving. Interessant hierbij is dat een deel van deze patiënten vier of meer positieve lymfklieren had maar dat dit in ieder geval tijdens de duur van deze studie niet resulteerde in een slechtere prognose in de radiotherapie-groep. De kwaliteit van leven verschilde ook niet tussen de twee behandelgroepen. De kans op lymfoedeem was groter in de groep met een okselklierdissectie ( $28 \%$ versus $14 \%$ ), maar schouderklachten traden frequenter op in de radiotherapiegroep. Zoals iedere studie, roept ook de AMAROS trial weer nieuwe vragen op. Bijvoorbeeld hoe uitgebreid de okselklierdissectie dient te zijn en wat de optimale bestralingsvelden en -dosis zijn. Vervolgstudies dienen uit te wijzen of een 
goede loko-regionale controle ook te realiseren is met een lagere stralingsdosis en of hierdoor de kans op fibrose in de oksel op de lange termijn kleiner is.

In Nederland bestaat discussie over de optimale benadering van de oksel en hoe de resultaten van de 20011 studie, de AMAROS studie en ook de observationele studies zoals beschreven in dit proefschrift vertaald dienen te worden naar behandeladviezen. Het voorstel op dit moment is om bij patiënten met micrometastasen in de schildwachtklier een aanvullend okselkliertoilet achterweg te laten wanneer er tevens sprake is van gunstige prognostische factoren en adjuvant systemische behandeling. Bij patiënten met micrometastasen en ongunstige prognostische factoren, zoals een slechte differentiatiegraad van het tumorweefsel of een grote tumor, wordt geadviseerd dat deze patiënten mogen kiezen tussen aanvullende okselklierdissectie dan wel radiotherapie van de oksel. Hetzelfde geldt voor patiënten met een macrometastase in één of twee schildwachtklieren zonder ongunstige prognostisch factoren, die borstsparende therapie ondergaan en adjuvante systemische behandeling ontvangen.

Om bij de individuele patiënt te bepalen of een minder uitgebreide chirurgische behandeling van de oksel verantwoord is moet vastgesteld worden in welke mate de potentieel hogere kans op een okselklierrecidief zicht vertaalt in een hoger risico op overlijden. De meta-analyse van de Early Breast Cancer Trialists Collaborative Group (EBCTCG) laat zien dat met het voorkomen van vier loko-regionale recieven in de eerste 10 jaar na de behandeling één sterftegeval voorkomen kan worden binnen een follow-up periode van 15 jaar. Wanneer aangenomen wordt dat dezelfde verhouding geldt voor okselklierrecidieven kan op basis van de resultaten van de Z0011 studie bepaald worden wat de invloed is op de overleving van het achterwege laten van een aanvullend okselkliertoilet bij patiënten met tumor van 5 centimeter of kleiner en een beperkte uitbreiding van de ziekte in de oksel. Wanneer hierdoor de kans op een okselklierrecidief binnen 10 jaar met $1 \%$ toeneemt zou dit resulteren in een toename van de sterfte met $0,25 \%$ na 15 jaar. In andere woorden: er zullen ongeveer 400 patiënten een aanvullende okselklierdissectie dienen te ondergaan om één sterftegeval te voorkomen. Het klinkt dus redelijk om door te gaan op de ingeslagen weg naar minder okselchirurgie en minder behandelingsgerelateerde morbiditeit en daarmee deze kleine toename in de kans op overlijden te accepteren.

Om de trend naar een minder invasieve behandeling van de oksel en een beter op de individuele patiënt toegesneden behandelplan te kunnen voortzetten, zal het nodig zijn om de beschikbare systemen te verbeteren waarmee de mate van uitbreiding van de ziekte in de oksel voorspeld kan worden. Van de patiënten met een macrometastasen in de schildwachtklier heeft maar 55\% klieren elders in de oksel die positief zijn. Dit impliceert dat minstens $45 \%$ van alle patiënten met een positieve schildwachtklierbiopsie geen voordeel heeft van een aanvullende okselklierdissectie 
maar wel het risico lopen om de bijwerkingen ervan te ondervinden. Daarnaast is het mogelijk dat een aanvullende okselklierdissectie niet nodig is bij patiënten die goed reageren op neoadjuvante chemotherapie. Dit is chemotherapie die wordt toegediend voorafgaand aan de operatie. Uit een recente retrospectieve studie in Zuid Nederland werd vastgesteld dat bij ongeveer een derde van de patiënten die behandeld zijn met neoadjuvante chemotherapie, en bij wie er voorafgaand aan die behandeling sprake was van positieve okselklieren, een complete pathologische remissie van de tumor was opgetreden (persoonlijke mededeling R.J. Schipper, Maastricht Universitair Medisch Centrum). De toename in het gebruik van neoadjuvante chemotherapie zal dus mogelijk ook resulteren in minder okselchirurgie bij vrouwen met borstkanker. Hierbij dient vermeld te worden dat het met de huidige nomogrammen nog niet goed mogelijk is om te voorspellen wie een complete remissie gaat hebben op systeemtherapie en wie niet. Bekend is dat de betrouwbaarheid van de schildwachtklierprocedure iets beter is als deze verricht wordt voordat de neo-adjuvante chemotherapie wordt gegeven. Maar het kan ook overwogen worden om de schilwachtklierprocedure na de afronding van de neoadjuvante chemotherapie uit te voeren. Dit zou bij patiënten met een complete remissie immers resulteren in meer negatieve uitslagen van de schilwachtklierprocedure. Het vaker toedienen van neo-adjuvante chemotherapie in combinatie met het uitstellen van de schildwachtklierprocedure zou zowel voor patiënten met een klinisch negatieve oksel als voor patiënten met een klinisch positieve oksel voordelen kunnen hebben. Een nadeel van een schildwachtklierprocedure na de neo-adjuvante chemotherapie is een lager opsporingspercentage en een hogere kans op foutnegatieve uitslagen. Deze nadelen moeten worden afgewogen tegen het aantal patiënten bij wie een onnodig okselklierdissectie kan worden voorkomen doordat sprake is van een volledig remissie van de tumor door de neo-adjuvante chemotherapie.

Met het groeiende inzicht in de moleculaire mechanismen die leiden tot borstkanker en de daarmee samenhangende verbeteringen in de systemische behandeling van de ziekte, ligt het in de lijn der verwachting dat een chirurgische behandeling van de oksel in de toekomst voor steeds minder patiënten noodzakelijk is. Ook verbeteringen in nomogrammen om de uitgebreidheid van de ziekte in de oksel te kunnen voorspellen gaan waarschijnlijk leiden tot een selectiever gebruik van het okselkliertoilet en dus beter maatwerk in de behandeling van borstkankerpatiënten. Daarnaast wordt het wellicht mogelijk om patiënten met een klinisch negatieve oksel te identificeren bij wie het vanuit het oogpunt van loko-regionale controle van de ziekte veilig is om zelfs de schildwachtklierprocedure achterwege te laten en bij wie de keuze voor adjuvante systemische behandeling bepaald kan worden op basis van de kenmerken van de primaire tumor. Een prospectief gerandomiseerd onderzoek, dat binnenkort in Nederland van start gaat, moet hierover uitsluitsel gaan geven. 
Op basis van bovengenoemde nieuwe inzichten en de nog op stapel staande onderzoeken kan geconcludeerd worden dat de verschuiving naar een minder invasieve chirurgische behandeling van de oksel bij patiënten met borstkanker zal doorzetten. De eerstvolgende voor de hand liggende stap na de publicatie van de resultaten van de Z0011 trial is dat bij geen enkele patiënt met een uitzaaiing in de schilwachtklier automatisch een okselklierdissectie wordt uitgevoerd, tenzij er sprake is van factoren die wijzen op zeer uitgebreide tumorgroei in de oksel. Dit zou al een radicaal andere benadering zijn dan het tot voor kort geldende beleid om bij alle patiënten met een positieve schildwachtklier een aanvullende okselklierdissectie te verrichten. Van deze nog selectievere toepassing van de okselklierdissectie gaan in Nederland de komende jaren duizenden patiënten baat hebben, omdat hun kans op lymfoedeem en andere klachten in de arm en schouder zal afnemen. 


\section{Valorisation}

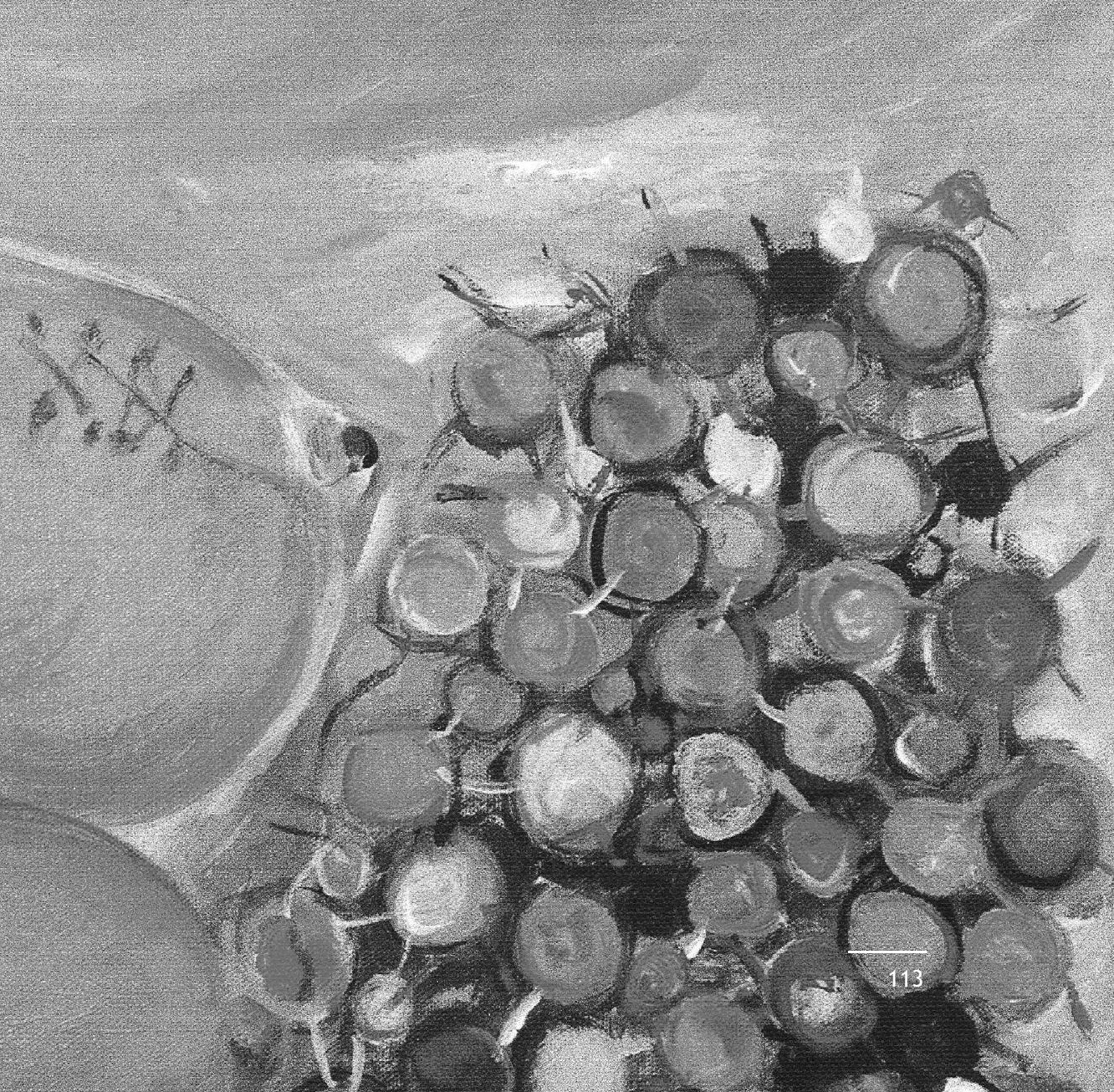




\section{Valorisation}

Knowledge valorisation refers to the process of translating research into products valuable for society. Society funds much of research generated, also true for some of the studies in this thesis, and society have the right to ask what value they gain from this. While research resulting in new knowledge can be valuable just for the sake of the knowledge gained, this section explores the societal and economic relevance of having performed these studies. To be precise, knowledge valorisation refers to the "process of creating value from knowledge, by making knowledge suitable and/or available for societal or economic use and by making knowledge suitable for translation into competitive products, services, processes and new commercial activities $^{\prime 1}$. The societal value of the studies presented in this thesis lie in the validation of improved treatment strategies resulting in less morbid treatment of the axilla and thus in less suffering for breast cancer patients and in a decrease of the number of axillary dissections performed. There are no commercial activities or competitive products born out of the research presented in this thesis.

The economic and societal burden of breast cancer is substantial. The worldwide incidence of breast cancer is 1.5 million. One in eight women in the Western world will develop breast cancer in her lifetime. Nearly all these women will have an operation and most will be additionally treated either before or after their operation with adjuvant hormone therapy, chemotherapy or radiation therapy. Each of these therapies results in substantial costs for society. Every improvement that allows for less treatment without compromising outcome is warranted.

This thesis presents studies that evaluate the shift in breast cancer treatment from a standard axillary lymph node dissection to the sentinel lymph node biopsy. The first three chapters cover studies on the safety of doing a sentinel lymph node biopsy without a follow up axillary lymph node dissection in women without sentinel lymph node metastases. These were done at a time when treatment guidelines recommended always performing an axillary lymph node dissection for primary breast cancer. There were, therefore, legitimate concerns about the safety of such a radical change in treatment strategy. While the sentinel node concept had been shown to be feasible, little was known about the outcome of care. Chapters 2 and 4 report the early and late results of the first 100 breast cancer women treated at the Máxima Medical Centre in Veldhoven who had a negative sentinel lymph node biopsy without further axillary lymph node dissection. Another way to look at this safety question is to compare sentinel lymph node biopsy negative women to historical axillary lymph node dissection negative women. This we did in chapter 3. 
What does this mean for the society that paid for this? In 2011, there were 13,987 women who were diagnosed with breast cancer in the Netherlands ${ }^{2}$. In other words, breast cancer incidence in the Netherlands is around 14,000 cases. About $70 \%(9,800)$ of these women undergo a sentinel lymph node biopsy; and of this $70 \%$ about $65 \%$ (6,370 women) will have no metastasis in their sentinel nodes and thus avoid further axillary lymph node dissection ${ }^{3}$. This change in treatment strategy, from a standard axillary lymph node dissection in all women with primary breast cancer to only a sentinel lymph node biopsy in biopsy negative women, has nearly halved the number of axillary lymph node dissections performed in the Netherlands. More than 6,000 women are thus spared the complications of having undergone an axillary lymph node dissection, such as pain, oedema, fatigue, etc. The three studies that make up the first part of this thesis contributed to the body of knowledge that supports this change in treatment strategy, and thus in support of this decrease in number of axillary lymph node dissections.

The second part of this thesis contains studies that try to identify sentinel lymph node positive breast cancer women who may also safely avoid completion axillary lymph node dissection. As mentioned above, $70 \%$ of the 14,000 annual breast cancer cases are treated with a sentinel lymph node biopsy. Of this $70 \%$ (9,800 women), $35 \%$ $(3,430$ women) will have metastasis in the sentinel node and undergo a completion axillary lymph node dissection. Up to $70 \%$ of sentinel node positive women have no further axillary metastases ${ }^{4}$. Thus up to 2,401 women ( $70 \%$ of the $35 \%$ above) will have undergone an axillary lymph node dissection without clear benefit from having undergone this procedure. The studies reported in the second half of this thesis contribute to the growing body of knowledge surrounding the search for sentinel node positive women who may safely avoid axillary lymph node dissection even though their sentinel node contains metastasis.

Besides the suffering, performing an axillary lymph node dissection also has a monetary value. The price billed to an insurance company for an axillary lymph dissection performed at the Máxima Medical Centre in 2014 is $€ 653,18$ euro ${ }^{5}$. Thus performing up to 2,401 negative axillary lymph node dissections after a positive sentinel lymph node biopsy results in more than $€ 1.5$ million annually in potentially unnecessary health care expenditure. While $€ 1.5$ million will not significantly change the national hospital health budget of the Netherlands, which is nearly €25 billion, every little bit helps ${ }^{6}$.

Overall, there are still 7,630 women per year in the Netherlands who undergo an axillary lymph node dissection, while at least 2,401 of them will have no benefit from having undergone the procedure. This brings us to the discussion we present in the future perspectives. What should we do going forward? One of the main discussions is the one surrounding predictive modelling, like those analyzed in chapter 9 of this 
thesis where we test nine models predicting non-sentinel node metastasis in sentinel lymph node positive breast cancer women. As modelling gets better, it will likely contribute towards more individualized care resulting in less unbeneficial procedures.

A major issue currently limiting predictive modelling is its acceptance among practitioners. It's interesting to note that when we quantify uncertainty, like we do in the models, especially surgeons become uncomfortable with the uncertainties. For example, Adjuvant online is a commonly used model to predict the added value of adjuvant systemic therapy. Its' reliability, however, is no higher than that of the models presented in chapter 9 . Mook et al. ${ }^{7}$ found a concordance index for Adjuvant online of 0.71 , hardly better than the MSKCC nomogram predicts non-sentinel node metastasis in sentinel node positive women (chapter 9 of this thesis). Medical practitioners feel comfortable using Adjuvant online to help determine the need for adjuvant systemic treatment, while surgeon don't feel comfortable using the MSKCC nomogram to support decision-making regarding an axillary lymph node dissection. Therefore work needs to be done both in improving model performance and in gaining predictive model acceptance among surgical practitioners.

In conclusion, the main value for society in having done the studies presented in this thesis lies in taking small steps towards less invasive axillary surgery in women with breast cancer without compromising patient outcome. Their value is in the validation of improved treatment protocols resulting in less morbid treatment of the axilla and thus in less suffering for breast cancer patients. Chapters 2-4 show that not performing a completion axillary lymph node dissection in sentinel node negative women is safe, supporting the paradigm shift from treating all women with breast cancer with an axillary lymph node dissection to only treating women with a positive sentinel node with an axillary lymph node dissection. Chapters 5-8 report studies performed in search of subgroups of sentinel node positive breast cancer patients who might safely avoid axillary lymph dissection. While no such group was identified, several steps were made. This ongoing journey will result in improved individualized care and ultimately in less axillary lymph node dissections being performed. The time seems near that we will go from a routine 'treat all women with sentinel node positive breast cancer with axillary lymph node dissection' to the treatment strategy of 'treat no sentinel node positive breast cancer woman with axillary lymph node dissection unless there is an exceptional reason to do so'. Such a change will be of value to society because it will result in less medical costs and less morbidity in the lives of individual women who suffer from breast cancer. 


\section{References}

1. Regulations governing the attainment of doctoral degrees. Maastricht University 2013:51.

2. http://www.nationaalkompas.nl/gezondheid-en-ziekte/ziekten-enaandoeningen/kanker/borstkanker/omvang/ [accessed 18 July, 2014].

3. Ho VK, van der Heiden-van der Loo M, Rutgers EJ, van Diest PJ, Hobbelink MG, Tjan-Heijnen VC, et al. Implementation of sentinel node biopsy in breast cancer patients in the Netherlands. Eur J Cancer 2008;44:683-91.

4. Charles Coutant, Camille Olivier, Eric Lambaudie, Eric Fondrinier, Frederic Marchal, Francois Guillemin, et al. Comparison of Models to Predict Nonsentinel Lymph Node Status in Breast Cancer Patients With Metastatic Sentinel Lymph Nodes: A Prospective Multicenter Study. J Clin Oncol 2009; 27:2800-8.

5. Personal communication Mirjam Hakkens, business controller Zorggroep Snijdend, Máxima Medical Centre.

6. http://statline.cbs.nl/StatWeb/publication/?DM=SLNL\&PA=71914ned\&D1=023\&D2=a\&HDR=G1\&STB=T\&VW=T. [Accessed on 12 August, 2014].

7. Mook S, Schmidt MK, Rutgers EJ, van de Velde AO, Visser O, Rutgers SM, et al. Calibration and discriminatory accuracy of prognosis calculation for breast cancer with the online Adjuvant! program: a hospital-based retrospective cohort study. Lancet Oncol 2009;10:1070-6. 


\section{Dankwoord}

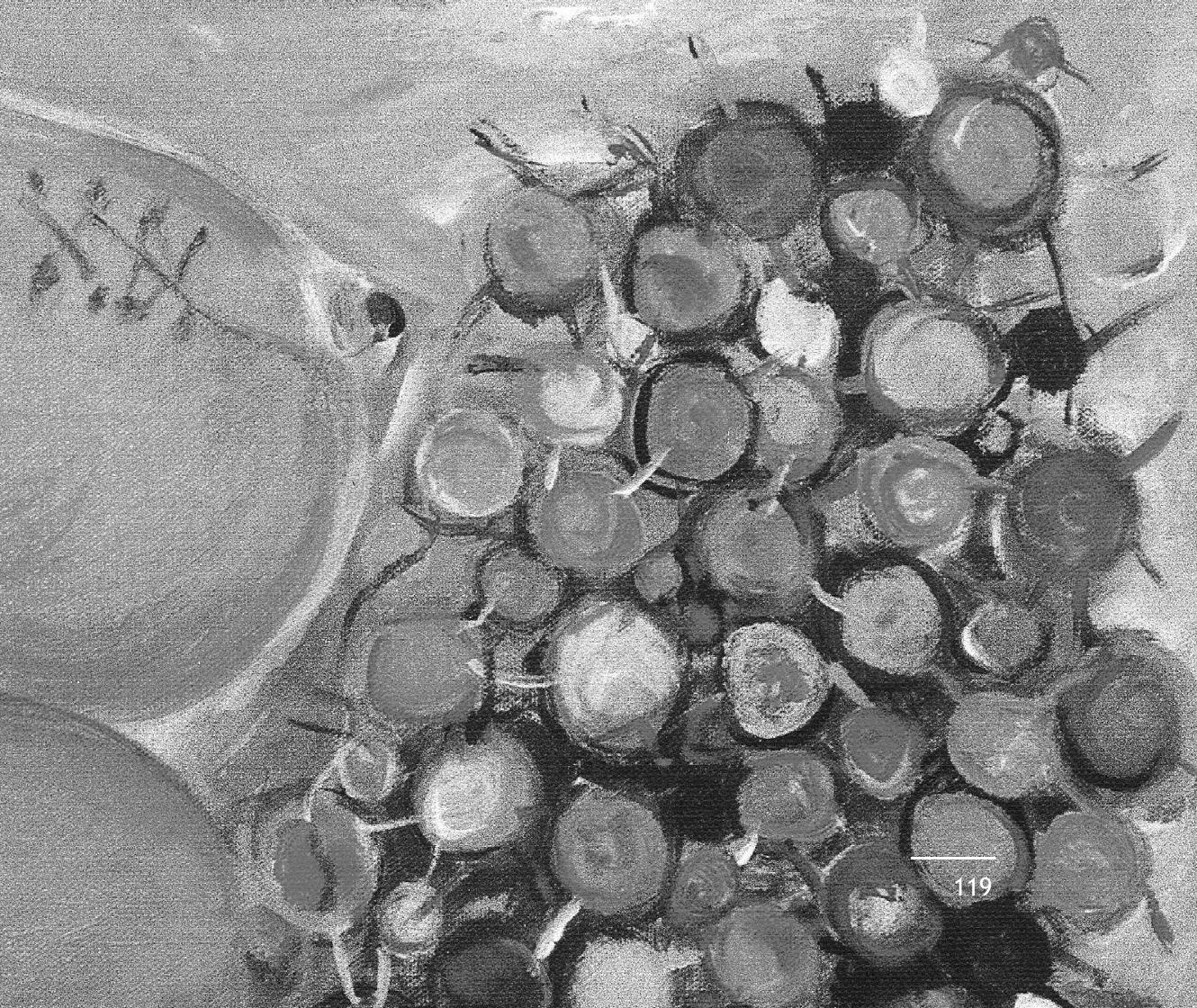





\section{Dankwoord}

Een gevoel van bescheidenheid overspoelt mij als ik reflecteer op de vele mensen die mij geholpen hebben bij het tot stand komen van dit proefschrift. Men doet niks alleen in deze wereld. Van mijn geboorte tot nu zijn er vele mensen geweest zonder wie ik hier nu niet zou staan. Te veel om op te noemen. Daarom ga ik me beperken tot die mensen die specifiek hebben bijgedragen aan het verwezenlijken van dit proefschrift.

Voordat ik begin wil ik hier graag mijn respect uitdragen naar alle vrouwen die hebben moeten lijden aan borstkanker en in het bijzonder naar die vrouwen wiens ziektegegevens als bron dienden voor de studies in dit proefschrift. Deze studies zijn verricht met het doel de zorg voor jullie te verbeteren.

Dr. Roumen, beste Rudi, zonder jou was dit proefschrift er nooit gekomen. Door jou ben ik hier aan begonnen en door jou heb ik het afgemaakt. Jouw creativiteit en wetenschappelijke drive zijn een voorbeeld. Inmiddels zijn wij maten, hetgeen betekent dat wij hopelijk nog lang samen verder kunnen.

Dr. Voogd, beste Adri, zonder jouw inzet was dit proefschrift er ook niet gekomen. Je was betrokken bij mijn eerste wetenschappelijke artikelen, en nu aan het eind heb je geholpen om het boekje af te krijgen. Daarnaast hebben we een gemeenschappelijke hobby, basketbal. Ik ben inmiddels niet meer klinisch actief in de mamma-oncologie, jouw onderzoeksgebied, maar ik hoop dat wij vrienden kunnen blijven via basketbal.

Prof. dr. Tjan-Heijnen, beste Vivianne, jij kwam er net op tijd bij om mij het laatste zetje te geven en dit werk af te maken. Zonder dat zetje was dit niet gelukt. Jij hebt een bijzonder praktische en doortastende aanpak waar ik respect voor heb. Bedankt voor je hulp.

Mede auteurs: drs. Mike v. Beek, drs. Ing Han Liem, prof. dr. Lonneke v d Poll-Franse, dr. Grard Nieuwenhuijzen, drs. Luc Scheijmans, drs. Ingrid v d Hoven, prof. dr. Ewout Steyerberg en dr. Yvonne Vergouwe. Jullie hebben allemaal een belangrijke bijdrage geleverd aan de artikelen in dit proefschrift, ieder op zijn of haar eigen manier. Daarvoor ben ik jullie dankbaar. In het bijzonder wil ik jou, Ingrid, bedanken. Jij kwam er halverwege de rit bij. Als ik terugdenk aan al die avonden en weekenddagen waar wij samen werkten aan onderzoek dan ben ik jou wel extra veel dank verschuldigd. Ook jou, Mike, wil ik apart bedanken. Je had het geduld om een chirurg in opleiding de beginselen van de pathologie aan te leren bij het bestuderen van de vele micrometastase-preparaten. Daarnaast waren de filosofische discussies, variërend van kwakzalverij in de geneeskunde tot het kraken van software, ook de moeite waard. 
Beoordelingscommissie: voorzitter prof. dr. Harm Rutten en leden prof. dr. Piet van den Brandt, dr. Thijs van Dalen en dr. Marjolein Smit. Bedankt voor de tijd en moeite die jullie hebben genomen om dit proefschrift te beoordelen.

Maatschapsleden chirurgie, verleden en heden, van het Máxima Medisch Centrum: Fred Croiset van Uchelen, Willem van Erp, Wouter Prakken, Jan Charbon, Karin Schenk, Ocker Repelaer van Driel, Bert den Butter, Peter Reemst, Mart Bender, Percy van Eerten, Francois van Dielen, Arijan Luijten, Rudi Roumen, Marc Scheltinga, Gerrit Slooter en binnen kort Wouter Leclercq. Het wordt vaak gezegd dat een maatschap veel lijkt op een huwelijk. Daar zit waarheid in. Gelukkig hebben wij een goed huwelijk, als ik dat zo mag zeggen. Met de jaren voel ik me steeds meer bevoorrecht dat ik tot deze groep mag behoren. Dank jullie allemaal voor jullie steun bij het tot stand komen van dit proefschrift, maar vooral ook bij alle andere zaken die wij samen ondernemen.

Secretariaat chirurgie: Annemieke Borgers, Anita van Loon, Marjon Reker, Riekie Rockx, Marjan v.d. Wiel en Mieke Kouwenberg-Doomen. Jullie zorgen er continu voor dat alles gesmeerd loopt bij de chirurgie in het MMC, zo ook met dit proefschrift. Wij vragen vaak hulp bij moeilijke taken die bij voorkeur gisteren al af moesten zijn en jullie maken het waar. Mieke, als persoon die specifiek over mij waakt, je informeerde niet alleen regelmatig naar de stand van zaken van dit proefschrift, je hebt ook het manuscript nagelezen, uitgeprint, rondgestuurd, enz. Ik dank jullie allemaal voor jullie hulp met dit proefschrift, maar ook voor het werk dat jullie elke dag doen.

Gezin: Mijn vrouw Christel en onze kinderen Gerrit, Lander, Willem en Emma. Jullie hebben de laatste 10 jaar wel vaker moeten horen dat je even moest wachten, want er moest aan het proefschrift gewerkt worden. Dat kwam thuis voor, in het weekend voor, maar ook op vakantie en op andere ongelegen momenten. Hopelijk komt er niet snel een volgend project, want dan sturen jullie mij misschien echt naar de schuur. Bedankt voor jullie steun en begrip. Reken op nog veel geweldige tijden samen.

Vriendschap is belangrijk voor mij. Niet van het soort van "ik kom drie keer per dag langs om je handje vast te houden", wel van het soort "ik kom rennen als er problemen zijn, maakt niet uit hoe groot, al kost het mij mijn leven". Daarom wil ik dit dankwoord afsluiten met de woorden van Avicii:

\section{AVICII LYRICS}

"Brother / Sister"

Hey brother, there's an endless road to re-discover.

Hey sister, know the water's sweet but blood is thicker.

Oh, if the sky comes falling down for you,

There's nothing in this world I wouldn't do. 
Hey brother, do you still believe in one another?

Hey sister, do you still believe in love, I wonder?

Oh, if the sky comes falling down for you,

There's nothing in this world I wouldn't do.

What if I'm far from home?

Oh, brother I will hear you call.

What if I lose it all?

Oh, sister I will help you out!

Oh, if the sky comes falling down for you,

There's nothing in this world I wouldn't do.

Hey brother, there's an endless road to re-discover.

Hey sister, do you still believe in love, I wonder?

Oh, if the sky comes falling down for you,

There's nothing in this world I wouldn't do.

What if I'm far from home?

Oh, brother I will hear you call.

What if I lose it all?

Oh, sister I will help you out!

Oh, if the sky comes falling down for you,

There's nothing in this world I wouldn't do.

Dus bij deze, aan alle mensen die zichzelf bevriend voelen met mij: "if the sky comes falling down for you, there's nothing in this world I wouldn't do. Even if you're far from home or have lost it all, there's nothing in this world I wouldn't do"!

Hartelijk bedankt allemaal. 



\section{Curriculum vitae}

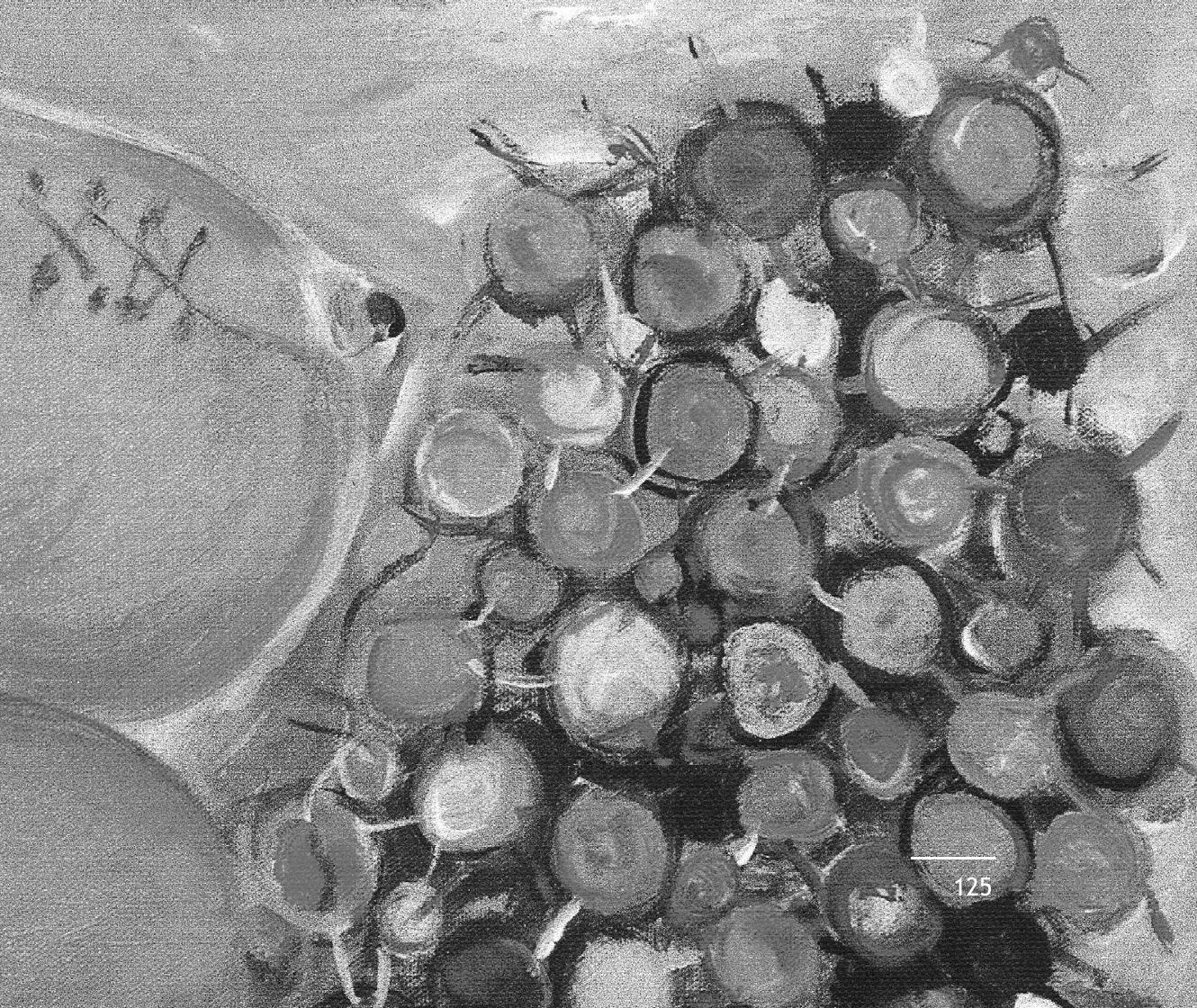





\section{Curriculum vitae}

Gerrit Paulus Kuijt is op 25 mei 1968 geboren in Angguruk, een klein plaatsje hoog in het gebergte van voormalig Nederlands Nieuw Guinea, waar zijn ouders 30 jaar gewerkt hebben als zendelingen. Vanaf de leeftijd van 6 jaar vertrok Gert twee keer per jaar met een vliegtuig naar school, eerst naar Sentani International School aan de kust van Papua en later naar Faith Academy High School net buiten Manilla, de Filippijnen. Na high school volgde hij de studie natuurkunde aan Valparaiso University in de Verenigde Staten als voorbereiding op de studie geneeskunde.

Op 20-jarige leeftijd kwam Gert naar Nederland voor de studie geneeskunde aan de Erasmus Universiteit in Rotterdam. Na 3 jaar assistent-geneeskunde-niet-in-opleiding te zijn geweest in het St. Elisabeth Ziekenhuis te Tilburg, is hij in 2001 begonnen aan de opleiding tot chirurg in de regio Nijmegen. De eerste vier jaar van de opleiding vonden plaats in het St. Joseph Ziekenhuis in Veldhoven, nu Máxima Medisch Centrum, met dr. Croiset van Uchelen als opleider. Daarop volgden twee academische jaren in het Radboud Universitair Medisch Centrum te Nijmegen onder leiding van prof. dr. Bleichrodt. In het laatste jaar heeft Gert zich gedifferentieerd in de traumatologie onder leiding van prof. dr. van Vugt te Nijmegen.

$\mathrm{Na}$ zijn opleiding is hij toegetreden tot de Maatschap Heelkunde in het Máxima Medisch Centrum. Eind 2007 is hij reserveofficier geworden bij de Koninklijke Landmacht. In de jaren daarna is hij door Defensie drie keer uitgezonden naar Afghanistan, als ook naar diverse plaatsen in Afrika. Met name het beoefenen van oorlogschirurgie in Afghanistan heeft een grote invloed gehad op zijn (professionele) leven.

De studies in dit proefschrift zijn begonnen in het derde jaar van de opleiding heelkunde onder begeleiding van dr. Roumen, co-promotor en chirurg in het Máxima Medisch Centrum, en van dr. Voogd, co-promotor en destijds epidemioloog bij het Integraal Kankercentrum Zuid. De afronding van het proefschrift vond plaats onder de begeleiding van prof. dr. Tjan-Heinen, promotor en medisch oncoloog in het Maastricht Universitair Medisch Centrum.

Gert woont sinds het begin van zijn opleiding in Oud-Turnhout, België, met zijn Vlaamse vrouw Christel en hun vier kinderen: Gerrit (17j), Lander (16j), Willem (14j) en Emma (12j). 
